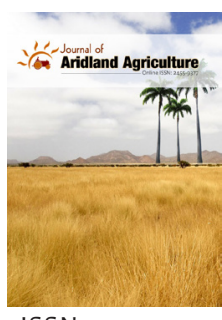

ISSN: $2455-9377$

\title{
Climate change and agriculture in Burkina Faso
}

\author{
Hamid El Bilali* \\ International Centre for Advanced Mediterranean Agronomic Studies (CIHEAM-Bari), Via Ceglie 9, 70010, \\ Valenzano (Bari), Italy
}

\begin{abstract}
The impacts of climate change (CC) are expected to be higher in developing countries (e.g. Sub-Saharan Africa). However, these impacts will depend on agriculture development and resilience. Therefore, this paper provides a comprehensive analysis of the multifaceted relationships between CC and agriculture in Burkina Faso (BF). A search performed in March 2020 on the Web of Science yielded 1,820 documents and 217 of them were included in the systematic review. The paper provides an overview on both bibliometrics (e.g. journals, authors, institutions) and topics addressed in the literature viz. agriculture subsectors, climate trends in BF, agriculture and CC mitigation (e.g. agriculture-related emissions, soil carbon sequestration), impacts of $\mathrm{CC}$ on agriculture (e.g. natural resources, crop suitability, yields, food security) as well as adaptation strategies. BF is experiencing $\mathrm{CC}$ as evidenced by warming and an increase in the occurrence of climate extremes. The literature focuses on crops, while animal husbandry and, especially, fisheries are often overlooked. Moreover, most of the documents deal with CC adaptation by the Burkinabe farmers, pastoralists and rural populations. Analysed adaptation options include conservation agriculture and climate-smart agriculture, irrigation, crop diversification, intensification, livelihoods diversification and migration. However, the focus is mainly on agricultural and individual responses, while livelihoods strategies such as diversification and migration are less frequently addressed. Further research is needed on the dual relation between agriculture and CC to contribute to the achievement of the Sustainable Development Goals. Research results are crucial to inform policies aimed at CC mitigation and/or adaptation in rural BF.
\end{abstract}

Received: November 21, 2020

Revised: February 07, 2021

Accepted: February 12, 2021

Published: March 04, 2021

KEYWORDS: Climate change mitigation, Climate change adaptation, Climate-smart agriculture, Rural livelihoods, Sahel, West Africa

*Corresponding Author:

Hamid El Bilali,

E-mail: elbilali@iamb.it

\section{INTRODUCTION}

Climate change is considered nowadays as one of the most pressing challenges facing humanity (Intergovernmental Panel on Climate Change, 2012; Steffen et al., 2015; United Nations, 2015). Climate change also represents a threat towards the achievement of the Sustainable Development Goals (SDGs) such as SDG2 "Zero Hunger" (Mugambiwa \& Tirivangasi, 2017). Agriculture is, on the one hand, a main contributor to climate change through greenhouse gas (GHG) emissions and, on the other hand, one of the sectors that are most affected by climate change (FAO, 2016; HLPE, 2012). Agriculture, forestry and other land uses (AFOLU) account for about one-fifth of GHG emissions worldwide (FAO, 2016). Therefore, both efforts for mitigation (Bennetzen et al., 2016; Elum et al., 2017; Forabosco et al., 2017; Kim et al., 2016; Minasny et al., 2017; Petersen et al., 2013; van Beek et al., 2010; Zomer et al., 2008) and adaptation (Bryan et al., 2013; Hertel \& Lobell, 2014; Loboguerrero et al., 2019; Rippke et al., 2016; Salinger et al., 2005; Suckall et al., 2015) are relevant in the context of agriculture. Indeed, Torquebiau (2017) suggests that "Agriculture is probably the most climate-dependent human activity and is both victim and responsible for climate change, while it can also be a solution to the climate change crisis".

Evidence shows that the impacts of climate change (CC) will be high in Sub-Saharan Africa (Baarsch et al., 2020; Bakshi et al., 2019; Bornemann et al., 2019; Hassan, 2010; Lokonon et al., 2019). Changes in climate will affect both temperatures (Faye et al., 2018; Issahaku et al., 2016; Thornton et al., 2011; Waha, Müller, \& Rolinski, 2013) and precipitation (Ayanlade et al., 2018; Le Houérou, 1996; Onyutha, 2018a; Waha, Müller, $\&$ Rolinski, 2013). Furthermore, as the primary sector still plays an important socio-economic role in the region, climate change will even affect the socio-economic development of these countries (Abidoye \& Odusola, 2015; Arndt et al., 2011; AsafuAdjaye, 2014; Azzarri \& Signorelli, 2020; Baarsch et al., 2020; Boubacar, 2015; Calzadilla et al., 2013; England et al., 2018; Lokonon et al., 2019; Montaud et al., 2017; Schlenker \& Lobell, 2010; Serdeczny et al., 2017). Indeed, agriculture contributes to the population's food security, and is an important source of income and livelihoods, especially in the rural areas, and a significant contributor to the national gross domestic product

Copyright: $\odot$ The authors. This article is open access and licensed under the terms of the Creative Commons Attribution License (http://creativecommons.org/licenses/by/4.0/) which permits unrestricted, use, distribution and reproduction in any medium, or format for any purpose, even commercially provided the work is properly cited. Attribution - You must give appropriate credit, provide a link to the license, and indicate if changes were made. 
(GDP) thanks to agricultural exports (Diao et al., 2007; FAO $\&$ OECD, 2015). Therefore, it is widely argued that climate change will also impact food security (Belay et al., 2019; Giannini et al., 2017; Hasegawa et al., 2018; Islam et al., 2016; Luetkemeier et al., 2018; Niles \& Brown, 2017; Olayide \& Alabi, 2018; Onyutha, 2018b; Palm et al., 2010; Richardson et al., 2018) and livelihoods (Aniah et al., 2019; Antwi-Agyei et al., 2014; Asfaw et al., 2019; Brottem \& Brooks, 2018; García de Jalón et al., 2017; Gautier et al., 2016; Jones \& Thornton, 2009; Kimani et al., 2015; Olayide \& Alabi, 2018; Sissoko et al., 2011) in Sub-Saharan Africa (SSA). Climate change is also a driver of migration (Kniveton et al., 2012; Luginaah et al., 2009; Pricope et al., 2013; Ruf et al., 2015; van der Land \& Hummel, 2013; Wiederkehr et al., 2018) and an important cause of conflicts (Benjaminsen et al., 2012; Buhaug et al., 2015; Hendrix \& Glaser, 2007; International Crisis Group, 2020; Pricope et al., 2013; von Uexkull, 2014) in SSA. In their analysis of climate change impact on development in Africa, Baarsch et al. (2020) raise "issues on the ability of African countries to reach their SDGs targets and the potential increasing risk of instability, migration across African countries, of decreased trade and economic cooperation opportunities as a consequence of climate change exacerbating its negative consequences".

Agriculture in SSA, which is predominantly rain-fed, is highly vulnerable to climate fluctuations and droughts (Abdulai, 2018; Adhikari et al., 2015; Asafu-Adjaye, 2014; Barrios et al., 2008; Cooper et al., 2008; Haile et al., 2019; Haile et al., 2018; Kahsay \& Hansen, 2016; Lokonon et al., 2019; Muchuru \& Nhamo, 2019; Müller, 2013; Muller et al., 2011; Pironon et al., 2019; Rippke et al., 2016; Schlenker \& Lobell, 2010; Sidibé et al., 2018; Sonwa et al., 2017; Webersik \& Wilson, 2009). Webersik and Wilson (2009) put that "African economies are closely linked to natural resources and rely heavily on agriculture, largely rain fed [...]. It is predicted that Africa will be particularly vulnerable to climate change and climate variability associated with biodiversity loss, food insecurity, water scarcity and an increase in drought frequency" (p. 400). Climate change affects particularly smallholder farmers (Boillat et al., 2019; Descheemaeker et al., 2016; Dixon \& Stringer, 2015; FAO, 2016; Freduah et al., 2019; García de Jalón et al., 2018; Gbegbelegbe et al., 2018; Lalou et al., 2019; Odame Appiah et al., 2018; Oluwatayo, 2019; Williams et al., 2018). The impacts of climate change on agriculture consists in the reduction of the production and yields of staple crops such as maize (Bedeke et al., 2020; Davenport et al., 2018; Epule et al., 2017; Faye et al., 2018; Freduah et al., 2019; Parkes et al., 2018; Shi \& Tao, 2014; Srivastava et al., 2018; Tesfaye et al., 2015; Waha, Müller, \& Rolinski, 2013), wheat (Trnka et al., 2019), rice (Akinbile et al., 2015; Daccache et al., 2015; Terdoo \& Feola, 2016; van Oort \& Zwart, 2018; Zhang et al., 2019), cassava (Jarvis et al., 2012; Pushpalatha \& Gangadharan, 2020; Rosenthal \& Ort, 2012), sorghum (Akinseye et al., 2020; Elagib et al., 2019; Faye et al., 2018; Mishra et al., 2008; Sultan et al., 2014), millet (Sultan et al., 2013). While most of the studies on the relationships between climate change and agriculture have focused on crop production, especially staple crops, a growing body of research deals with climate change impacts on livestock (Brandt et al., 2018, 2020; Forabosco et al., 2017; Gerssen-Gondelach et al.,
2017; Godber \& Wall, 2014; Henderson et al., 2017; Houessou et al., 2019; Liverpool-Tasie et al., 2019; Mare et al., 2018; Naah \& Braun, 2019; Salmon et al., 2018). There are also more and more studies on the effects of climate change on fisheries in Africa (Belhabib et al., 2016; Freduah et al., 2019; Lam et al., 2012; Lauria et al., 2018; Limuwa et al., 2018; Nyboer et al., 2019; Thiaw et al., 2017). Many international organisations and scholars highlighted the benefits of climate-smart agriculture (CSA) (Abegunde et al., 2019; Amadu et al., 2020; Andrieu et al., 2017; García de Jalón et al., 2017; Makate et al., 2019; Raile et al., 2019; Totin et al., 2018; Zougmoré et al., 2019), conservation agriculture (Boillat et al., 2019; Corbeels et al., 2014, 2019; Dougill et al., 2017; Komarek et al., 2019; Powlson et al., 2016; Thierfelder et al., 2018; Worou et al., 2019) and agroforestry (Corbeels et al., 2019) both for climate change mitigation and adaptation. Indeed, agriculture can also contribute to mitigate climate change by reducing GHG emissions (Bellassen et al., 2010; Suckall et al., 2015; Takimoto et al., 2008; Vågen et al., 2005; van Loon et al., 2019). Loboguerrero et al. (2019) argue that "Climate-smart agriculture can help foster synergies between productivity, adaptation, and mitigation". Climate change also affects availability of and access to natural resources such as water (Adnew Degefu et al., 2019), land (Conradie et al., 2019; Marchant et al., 2018) and ecosystem services (Koo et al., 2019; Marchant et al., 2018; Scheiter \& Savadogo, 2016). Some scholars argue that climate change impacts will likely be higher on women thus highlighting the need for a gender-sensitive approach in the adaptation to climate change (Bryan et al., 2018; Chah et al., 2018; Djoudi \& Brockhaus, 2011; Jost et al., 2016; Onwutuebe, 2019; Rao, 2019).

In the context of SSA, the Sahel and West Africa regions seem particularly vulnerable to climate change (Baarsch et al., 2020). Indeed, referring to the Sahel region, Zhang et al. (2019) put that "the region is vulnerable to unfavorable weather and has a very low adaptive capacity". Sultan and Gaetani (2016) highlight that "West Africa is known to be particularly vulnerable to climate change due to high climate variability, high reliance on rain-fed agriculture, and limited economic and institutional capacity to respond to climate variability and change". Therefore, it is expected that the West African countries of the Sahel will be severely hit by climate change. Egbebiyi et al. (2019) posit that "The changing climate is posing significant threats to agriculture, the most vulnerable sector, and the main source of livelihood in West Africa". In this context, and referring to a West African and Sahelian country such as Burkina Faso, Zidouemba (2017) argues that the "economic development in Burkina Faso is potentially vulnerable to climate change, given the country's dependence on rain-fed agriculture" (p. 2797). Indeed, Burkina Faso (BF) is considered as one of the most vulnerable countries to climate change in Africa (Busby et al., 2014). BF, a landlocked country in the Sahelian West Africa, has a low Human Development Index (HDI, ranking 182 out of 189 countries) (UNDP, 2019) and is affected by multiple forms of malnutrition (FAO et al., 2018; USAID, 2018). Indeed, the prevalence of undernourishment was $14.1 \%$ in $2015-17$ period and there were about 3.0 million undernourished people in the country over the same period (FAO et al., 2018). Furthermore, micronutrient deficiencies (e.g. iodine, iron, vitamin A) are widespread in the country (Institut 
National de la Statistique et de la Démographie \& ORC Macro, 2004; USAID, 2018). Likewise, poverty is widespread as $43.7 \%$ of the Burkinabe population lives below the poverty line of 1.90 USD per day (World Bank, 2019). The country should also fill the gap in terms of sustainable development as it ranks $138^{\text {th }}$ out of 157 countries in progress toward meeting the SDGs (Sachs et al., 2017; USAID, 2018). Agriculture is a leading sector in the Burkinabe economy; it contributes to $28.6 \%$ of GDP and $28.3 \%$ of employment (World Bank, 2019). Staple crops include cereals (e.g. sorghum, millet, maize, rice) and legumes (e.g. cowpea), while groundnut and cotton represent the major cash crops (USAID, 2017). Nonetheless, agriculture is extensive and almost entirely reliant on the summer rainfall (June-September), thus making it particularly vulnerable to CC. Indeed, high rainfall variability characterises the local climate (Mainardi, 2011; USAID, 2017). Therefore, this review paper analyses the state of research on the relation between climate change and agriculture in Burkina Faso. The paper reviews both the contribution of agriculture to climate change in terms of GHG emissions as well as the adaptation of Burkinabe agriculture to the changing climate.

\section{METHODS}

The article draws upon a systematic review of records indexed in all databases of Clarivate Analytics - Web of Science (viz. Web of Science Core Collection, Current Contents Connect, MEDLINE $^{\circledR}$, KCI-Korean Journal Database, SciELO Citation Index, Russian Science Citation Index). The review follows the PRISMA guidelines (Preferred Reporting Items for Systematic Reviews and Meta-Analyses) (Moher et al., 2009). A search was performed on 23 March 2020 using the following string: (Burkina OR Sahel OR "West Africa” OR "Sub-Saharan Africa”) AND (\{climate change $\}$ OR “climate variability” OR "global warming”) AND (agriculture OR agro OR horticulture OR "animal husbandry" or "livestock" OR fish). The literature search yielded 1,820 records.

The methodology used in documents selection was informed by that adopted by El Bilali $(2019,2020)$. The selection of documents included in the systematic review is described in Table 1. In the context of the present paper, agriculture is considered to include crop production, animal production and fisheries. Furthermore, while forestry is not considered in the present paper, documents dealing with agroforestry were included in the systematic review. Meanwhile, documents dealing with the impacts of climate change on protected areas, parks and wildlife were excluded. For being eligible for the present systematic review, each document had to meet simultaneously three criteria relating to the topical focus (viz. document deals with both climate change and agriculture), geographical coverage (viz. document deals with $\mathrm{BF}$ ) and the type of document (viz. document is an article, a conference paper or a book chapter; letters to editors, editorial comments and/or notes were not considered). Furthermore, since the paper deals with research on the relationships between climate change and agriculture, only research articles were considered (i.e. reviews were excluded).

Based on the screening of titles, 824 documents were excluded as they do not refer to BF; documents that cover wide geographical areas that include BF (e.g. Sahel, West Africa, SSA, Economic Community of West African States - ECOWAS) were kept for further scrutiny. Further 621 documents were discarded following the analysis of abstracts as they do not meet one or more of the inclusion criteria. For instance, many articles refer to climate change in their introduction but they deal with other topics. Moreover, 258 documents were excluded after scrutiny of full-texts. These also include 52 reviews, systematic reviews and meta-analyses (Abegunde et al., 2019; Agrawal et al., 2014; Belhabib et al., 2016; Biazin et al., 2012; Botha et al., 2020; Brown et al., 2011; Cairns et al., 2012; Carr et al., 2020; Chuku \& Okoye, 2009; Corbeels et al., 2019; Druyan, 201 1; Epule et al., 2014; Forabosco et al., 2017; Gautier et al., 2016; Gil et al., 2017; Hansen et al., 2011; Hassen et al., 2017; Islam et al., 2016; Katikiro \& Macusi, 2012; Kim et al., 2016; Koubi, 2019; Lahive et al., 2019; Lal, 2019; Loboguerrero et al., 2019; Makate, 2019; Mbow et al., 2014; Mngumi, 2020; Muchuru \& Nhamo, 2019; Müller, 2013; Muller et al., 2011; Mundia et al., 2019; Mutuo et al., 2005; Nkiaka et al., 2019; Nkrumah, 2019; Partey et al., 2018; Powlson et al., 2016; Pushpalatha \& Gangadharan, 2020;

\section{Table 1: Systematic review steps and process}

\begin{tabular}{|c|c|c|}
\hline Selection steps & Selected documents number & Number of documents excluded and exclusion reasons \\
\hline Initial search and records identification & 1,820 & -- \\
\hline Screening of documents based on titles & 1,820 & $\begin{array}{l}824 \text { documents excluded because they deal with other countries than BF } \\
\text { e.g., Benin, Botswana, Cameroon, Congo, Democratic Republic of Congo, } \\
\text { Ethiopia, Ghana, Guinea-Bissau, Ivory Coast, Kenya, Madagascar, } \\
\text { Malawi, Mali, Mozambique, Namibia, Niger, Nigeria, Rwanda, Senegal, } \\
\text { Sierra Leone, Somalia, South Africa, South Sudan, Sudan, Swaziland, } \\
\text { Tanzania, Togo, Uganda, Zimbabwe. }\end{array}$ \\
\hline Screening of documents based on abstracts & 996 & $\begin{array}{l}621 \text { documents exclud ed: } \\
\text { - } 396 \text { documents because they do not deal with BF } \\
\text { - } 199 \text { documents because they do not address climate change } \\
\text { - } 26 \text { documents because they don't deal with agriculture }\end{array}$ \\
\hline Scrutiny of full-texts & 375 & $\begin{array}{l}258 \text { documents excluded: } \\
\text { - } 105 \text { records because they do not address BF } \\
\text { - } 87 \text { documents because they don't deal with climate change } \\
\text { - } 14 \text { documents because they don't deal with agriculture } \\
\text { - } 52 \text { reviews were discarded }\end{array}$ \\
\hline Inclusion of documents in the systematic review & 117 & -- \\
\hline
\end{tabular}


Ramirez-Villegas \& Challinor, 2012; Rhodes \& Atewamba, 2019; Roudier et al., 2011; Sarr, 2012; Shcherbak et al., 2014; Sileshi et al., 2019; Snapp et al., 2019; Sultan \& Gaetani, 2016; Terdoo \& Feola, 2016; Totin et al., 2018; Vaughan et al., 2019; Webber et al., 2014; Wilcox et al., 2019; Williams et al., 2018; Zougmoré et al., 2018). Consequently, 117 documents were selected and underwent bibliometric and topical analyses (Table 2).

The systematic review of the selected documents regarded both bibliographical metrics and topical focus of research on climate change and agriculture in BF (Table 3).

\section{RESULTS AND DISCUSSION}

\section{Bibliographical Metrics of Research on Climate Change and Agriculture in Burkina Faso}

The biblio-metrics (e.g. sources/journals, subject areas, authors, institutions, countries) for research on climate change and agriculture in $\mathrm{BF}$ are shown in Table 4.

The analysis of bibliographical data suggests an increasing academic interest in the nexus between climate change and

Table 2: Documents included in the systematic review

\begin{tabular}{cc}
\hline Year & Documents number \\
\hline 2020 & 5 \\
2019 & 22
\end{tabular}

References

Ayantunde et al. (2020); Azzarri and Signorelli (2020); Döring (2020); Prestele and Verburg (2020); Tankari (2020) Quintero and Cohen (2019); Berthou et al. (2019); Belesova et al. (2019); Nelimor et al. (2019); Kamali et al. (2019); Lokonon et al. (2019); Zhang et al. (2019); Serpantié et al. (2019); Pironon et al. (2019); Cobbing and Hiller (2019); Sultan et al. (2019); Zampaligré and Fuchs (2019); Rauch et al. (2019); Egbebiyi et al. (2019a); Egbebiyi et al. (2019b); van Loon et al. (2019); Nyboer et al. (2019); Sidibe et al. (2019); Sultan et al. (2019); Ugbaje et al. (2019); Zouré et al. (2019); Boansi et al. (2019)

$201830 \quad$ Bicher and Diedhiou (2018); Bryan et al. (2018); Bunclark et al. (2018); Callo-Concha (2018); Chen et al. (2018); de Vrese et al. (2018); Dimobe et al. (2018); Doelman et al. (2018); Egbendewe (2018); Fanzo et al. (2018); Faye et al. (2018); Ferner et al. (2018); Garcia de Jalon et al. (2018); Garnot et al. (2018); Hasegawa et al. (2018); Henderson et al. (2018); Hoffman et al. (2018); Kamali et al. (2018); Klutse et al. (2018); Olusegun et al. (2018); Onyutha (2018a); Parkes et al. (2018); Rasmussen (2018); Richardson et al. (2018); Sidibé et al. (2018); Steward et al. (2018); Sylla et al. (2018a); Sylla et al. (2018b); Thomas and Nigam (2018); van Oort and Zwart (2018)

$2017 \quad 30 \quad$ Andam-Akorful et al. (2017); Asare-Kyei et al. (2017); Belem and Saqalli (2017); Boansi et al. (2017); Choptiany et al. (2017); Dale et al. (2017); Defrance et al. (2017); Egbendewe et al. (2017); Gaisberger et al. (2017); Guan et al. (2017); Hadebe et al. (2017); Henderson et al. (2017); Jahel et al. (2017); Jun (2017); McPeak (2017); Niles and Brown (2017); Ogundari et al. (2017); Oguntunde et al. (2017); Ouédraogo et al. (2017); Palazzo et al. (2017); Rigolot et al. (2017); Sanfo et al. (2017); Serdeczny et al. (2017); Sonwa et al. (2017); Sossa et al. (2017); Tabeau et al. (2017); Torquebiau (2017); Wang et al. (2017); Witmer et al. (2017); Zidouemba (2017)

2016 Ahmed et al. (2016); Amjath-Babu et al. (2016); Bennetzen et al. (2016); Bodin et al. (2016); Borona et al. (2016); Callo-Concha (2016): Descheemaeker et al. (2016); Di Leo et al. (2016); Douxchamps et al. (2016); Dunning et al. (2016); Gray and Wise (2016); Hänke et al. (2016); Henderson et al. (2016); Huyer (2016); Mertz et al. (2016); Rippke et al. (2016); Salack et al. (2016); Scheiter and Savadogo (2016); Siebert (2016); Sorgho et al. (2016); Stith et al. (2016); van Wesenbeeck et al. (2016); von Uexkull et al. (2016); Waha et al. (2016)

$201519 \quad$ Abidoye and Odusola (2015); Ahmed et al. (2015); Buhaug et al. (2015); Dixon and Stringer (2015); Fonta et al. (2015); Gahi et al. (2015); Guan et al. (2015); Kamoni and Gicheru (2015); Kima et al. (2015); Lebel et al. (2015); Mande et al. (2015); Oyekale (2015); Parkes et al. (2015); Rasmussen et al. (2015); Salack et al. (2015); Sylla et al. (2015); Tesfaye et al. (2015); Thornton and Herrero (2015); Waongo et al. (2015)

201426 Asafu-Adjaye (2014); Bayala et al. (2014); Busby et al. (2014); Chaney et al. (2014) agriculture, and infrastructure is necessary to adequately prepare and adapt to future change. This is a challenge in data-sparse regions such as sub-Saharan Africa, where a lack of high-density and temporally consistent long-term in situ measurements complicates the analysis. To address this, a temporally homogenous and high-temporal- and high-spatial-resolution meteorological dataset is developed over sub-Saharan Africa $\left(5^{\circ} \mathrm{S}-25^{\circ} \mathrm{N}\right.$; Corbeels et al. (2014); Coulibaly et al. (2014); D'haen et al. (2014); Folberth et al. (2014); Johnson and Brown (2014); Kima et al. (2014); Lambin et al. (2014); Lodoun et al. (2014); López-Carr et al. (2014); Naumann et al. (2014); Rasmussen et al. (2014); Seo (2014); Sheffield et al. (2014); Shi and Tao (2014); Sultan et al. (2014); Thornton and Herrero (2014); vom Brocke et al. (2014); von Uexkull (2014); Waongo et al. (2014); Ward et al. (2014); Wood et al. (2014); Zampaligré et al. (2014)

\begin{tabular}{|c|c|c|}
\hline 2013 & 14 & $\begin{array}{l}\text { Calzadilla et al. (2013); Faramarzi et al. (2013); Heubes et al. (2013); Liu et al. (2013); Lobell et al. (2013); Mahe } \\
\text { et al. (2013); Ramirez-Villegas et al. (2013); Sultan et al. (2013); Traore and Owiyo (2013); Vrieling et al. (2013); } \\
\text { Waha et al. (2013a); Waha et al. (2013b); Yang et al. (2013); Zorom et al. (2013) }\end{array}$ \\
\hline 2012 & 10 & $\begin{array}{l}\text { Brockhaus et al. (2012); Haussmann et al. (2012); Jarvis et al. (2012); Jung et al. (2012); Kniveton et al. (2012); } \\
\text { Lahmar et al. (2012); Luedeling and Neufeldt (2012); Rosenthal and Ort (2012); Rudi et al. (2012); Tittonell et al. (2012) }\end{array}$ \\
\hline 2011 & 10 & $\begin{array}{l}\text { Arthur and Baidoo (2011); Belem et al. (2011); Bhaduri et al. (2011); Kalame et al. (2011); Mertz (2011); Paeth } \\
\text { (2011); Proud and Rasmussen (2011); Sissoko et al. (2011); Thornton et al. (2011); Traoré et al. (2011) }\end{array}$ \\
\hline 2010 & 5 & Garrity et al. (2010); Mertz et al. (2010); Nielsen and Reenberg (2010); Schlenker and Lobell (2010); Zorom et al. (2010) \\
\hline 2009 & 5 & Barbier et al. (2009); Jones and Thornton (2009); Lay et al. (2009); Ramin and McMichael (2009); Seo et al. (2009) \\
\hline 2008 & 6 & $\begin{array}{l}\text { Barrios et al. (2008); Cooper et al. (2008); Lobell et al. (2008); Mishra et al. (2008); Vrieling et al. (2008); West } \\
\text { et al. (2008) }\end{array}$ \\
\hline 2007 & 4 & Bostick et al. (2007); Hendrix and Glaser (2007); Perez et al. (2007); Wittig et al. (2007) \\
\hline 2005 & 2 & Haile (2005); Wang (2005) \\
\hline 2002 & 4 & Groten and Ocatre (2002); Ingram et al. (2002); Ringius (2002); Taylor et al. (2002) \\
\hline 2001 & 1 & Roncoli et al. (2001) \\
\hline
\end{tabular}


Table 3: Topics addressed in the systematic review

\begin{tabular}{ll}
\hline Item & Elements analysed in the selected documents \\
\hline Bibliographical metrics & Subject areas, sources/journals, authors, affiliation institutions, affiliation countries, study countries \\
Topical focus of research on climate change & Agriculture subsectors: crop production, animal production and fisheries \\
and agriculture in BF & Changing climate in BF (e.g. trends in air temperature and rainfall, droughts, extreme weather events) \\
& Agriculture and climate change mitigation (e.g. GHG emissions from agriculture, soil carbon \\
& sequestration, conservation agriculture) \\
& Impacts of climate change on Burkinabe agriculture (e.g. impacts on agricultural production and yields, \\
& crop suitability, natural resources, food security, pests and diseases, conflicts) \\
& Adaptation of Burkinabe agriculture to climate change (e.g. crop diversification, intensification, \\
& irrigation, livelihoods diversification, migration) \\
\hline
\end{tabular}

Table 4: Bibliographical metrics of the literature on climate change and agriculture in BF: top-ten journals, research areas, authors, affiliations and countries

\begin{tabular}{|c|c|c|c|c|}
\hline Journals (a) & Research areas (b) & Authors (c) & Affiliations (d) & Countries (e) \\
\hline Climatic Change (10) & $\begin{array}{l}\text { Environmental Sciences - } \\
\text { Ecology (97) }\end{array}$ & Sultan, B. (9) & CIRAD (17) & USA (66) \\
\hline $\begin{array}{l}\text { Environmental } \\
\text { Research Letters (10) }\end{array}$ & $\begin{array}{l}\text { Meteorology - Atmospheric } \\
\text { Sciences (61) }\end{array}$ & Mertz, 0. (8) & University of Copenhagen (15) & $\begin{array}{l}\text { Burkina } \\
\text { Faso (47) }\end{array}$ \\
\hline $\begin{array}{l}\text { Agricultural } \\
\text { Systems (8) }\end{array}$ & Agriculture (38) & Thornton, P. K. (7) & Helmholtz Association (13) & Germany (45) \\
\hline $\begin{array}{l}\text { Global Environmental } \\
\text { Change ( } 7 \text { ) }\end{array}$ & Science Technology (22) & Baron, C. (6) & $\begin{array}{l}\text { Institut de Recherche pour le } \\
\text { Développement-IRD (13) }\end{array}$ & France (31) \\
\hline $\begin{array}{l}\text { Regional } \\
\text { Environmental } \\
\text { Change (6) }\end{array}$ & Business Economics (15) & Herrero, M. (6) & ILRI (13) & England (28) \\
\hline Climate (5) & Geology (15) & Kunstmann, H. (6) & Wageningen University Research (13) & Kenya (28) \\
\hline $\begin{array}{l}\text { Global and Planetary } \\
\text { Change (5) }\end{array}$ & Geography (14) & Lobell, D. B. (6) & $\begin{array}{l}\text { International Food Policy Research } \\
\text { Institute - IFPRI (12) }\end{array}$ & Netherlands (22) \\
\hline Journal of Climate (5) & Water Resources (11) & Yang, H. (6) & Columbia University (11) & Australia (18) \\
\hline $\begin{array}{l}\text { Nature Climate } \\
\text { Change (5) }\end{array}$ & Development Studies (9) & $\begin{array}{l}\text { Barbier, B.; Bayala, } \\
\text { J.; Nielsen, J.O.; }\end{array}$ & Karlsruhe Institute of Technology (11) & Denmark (17) \\
\hline PLOS One (5) & Food Science Technology (7) & $\begin{array}{l}\text { Rasmussen, K.; } \\
\text { Rasmussen, L.V. (5) }\end{array}$ & $\begin{array}{l}\text { CNRS, Commonwealth Scientific Industrial } \\
\text { Research Organisation (CSIRO), ICRISAT, } \\
\text { Sorbonne Université, University of Bonn, } \\
\text { ICRAF (10) }\end{array}$ & Mali (16) \\
\hline
\end{tabular}

Legend: Figures in brackets refer to the number of documents by journal (a), research area (b), author (c),

affiliation institution (d), or affiliation country (e)

agriculture in BF and beyond (e.g. West Africa, Sahel). Indeed, the average yearly output of articles in the considered period (2001-2020) is about 11; it ranges from one in 2001 to a maximum of 30 papers published in 2017 and 2018.

As for journals and sources, the highest number of papers was published in Climatic Change (10 articles), Environmental Research Letters (10 articles), Agricultural Systems (8 articles), and Global Environmental Change (7 articles). Nevertheless, the results of the research on climate change and agriculture in $\mathrm{BF}$ were published in 116 sources and journals. Most of the selected documents are linked to the research areas of environmental sciences - ecology ( 97 documents), meteorology - atmospheric sciences (61 documents) and agriculture (38 documents). Nonetheless, the selected documents can be categorized in 35 research areas (e.g. business economics, geography, development studies, computer science, engineering, mathematics, geochemistry, geophysics), which might indicate the 'multidisciplinarity' of the research field.

The most prominent scholars in the research field are Benjamin Sultan (9 documents), Ole Mertz (8 documents) and Philip K.
Thornton (7 documents). Meanwhile, the analysis of author affiliations and countries shows that most of the research on climate change and agriculture in $\mathrm{BF}$ was carried out by researchers based in developed countries in North America (viz. USA, Canada), Europe (e.g. Germany, France, England, Netherlands, Denmark, Italy, Switzerland, Spain, Sweden, Belgium) and Oceania (viz. Australia). Collaborations of Burkinabe scientists with researchers from developed countries are needed and should be encouraged. Moreover, it is worth mentioning that many scientists based in Africa, especially West Africa (e.g. Kenya, Mali, Niger, Nigeria, Ghana, South Africa, Ivory Coast, Senegal, Zimbabwe, Benin), are active in the research field. This might be explained, among others, by the fact that many international organisations (e.g. CGIAR) have branches in Africa (e.g. International Livestock Research Institute - ILRI, International Crops Research Institute for the Semi-Arid Tropics - ICRISAT, World Agroforestry - ICRAF). Moreover, more and more studies are performed by researchers based in China. The most prominent institutions, as per author affiliations, are the French Agricultural Research Centre for International Development - CIRAD (17 documents) and the University of Copenhagen (15 documents). Active Burkinabe 
research centres and institutions include the Centre National de la Recherche Scientifique (CNRS) and the University of Ouagadougou.

Most of the selected documents (45.2\% i.e. 98 documents out of 217) deal with the whole Sub-Saharan Africa (see, Supplementary Material - Appendix 1). These are followed by some multi-country - e.g. BF with a neighbouring country such as Benin (Callo-Concha, 2018, 2016) or Ghana (Boansi et al., 2017, 2019) - and regional (West Africa, Sahel) studies $(31.8 \%$ i.e. 69 out of 217). Less than a quarter of the selected studies (23.0\% i.e. 50 out of 217) address the relationships between agriculture and climate change in Burkina Faso or even single regions in the country e.g. north (Hänke et al., 2016; Kima et al., 2014; Rigolot et al., 2017), south (Borona et al., 2016; Dimobe et al., 2018), south-west (Fonta et al., 2015; Sanfo et al., 2017) and south-east (Mande et al., 2015).

\section{Agriculture Subsectors: Crop Production, Animal Production and Fisheries}

Most of the selected papers deal with crop production, while animal production (7 documents out of 217) and, especially, fisheries (1 document) are overlooked (see, Supplementary Material - Appendix 2). As for crop production (82 documents out of 217), the majority of articles addresses climate change mitigation and/or adaptation in relation to staple crops - such as cassava (Egbebiyi, Crespo, et al., 2019; Egbebiyi, Lennard, et al., 2019; Jarvis et al., 2012; Rosenthal \& Ort, 2012), maize (Kamali et al., 2018, 2019; Nelimor et al., 2019; Parkes et al., 2018; Ugbaje et al., 2019), millet (Egbebiyi, Crespo, et al., 2019; Faye et al., 2018; Pironon et al., 2019; Sultan et al., 2013; Sultan, Defrance, et al., 2019), rice (Kima et al., 2014; van Oort \& Zwart, 2018; Zhang et al., 2019), sesame (Lokonon et al., 2019), sorghum (Akinseye et al., 2020; Hadebe et al., 2017; Sultan et al., 2014; Sultan, Defrance, et al., 2019; vom Brocke et al., 2014), and yam (Pironon et al., 2019) - or cash crops such as cotton (Bostick et al., 2007; Ingram et al., 2002; Zorom et al., 2010), mango (Egbebiyi, Crespo, et al., 2019), sugarcane (Lokonon et al., 2019) and groundnuts (Hoffman et al., 2018; Schlenker \& Lobell, 2010). Most of the selected documents deal with 'rural agriculture', while urban and peri-urban agriculture (UPA) is marginal (Nkrumah, 2019). Many papers analyse the impacts of climate change on mixed systems (96 documents out of 217) such as agro-pastoral systems. This is particularly the case of documents that address climate change adaptation by rural and agricultural households. Further documents (31 documents out of 217) deal with both agriculture and forestry (e.g. agroforestry). This category also includes articles that analyse changes in land use in agricultural areas due to changing climate in BF or West Africa and Sahel at large.

\section{Topics Addressed in the Research Field}

\section{Changing climate in BF: trends in air temperature and rainfall}

The analysis of changes in climate is based on modern knowledge (cf. conventional science) and/or traditional/indigenous knowledge. The former consists in retrospective studies, which analyse past changes in temperatures and/or rainfall in BF, or prospective studies that provide projections of temperatures and/or rainfall based on methods such as modelling or scenarios. The latter approach encompasses analysing the perceptions and opinions of the concerned actors (e.g. farmers, pastoralists) about the changing climate in the country.

Sultan and Gaetani (2016) suggest that "West Africa is nowadays experiencing a rapid climate change, characterized by a widespread warming, a recovery of the monsoonal precipitation, and an increase in the occurrence of climate extremes". As for warming, Sultan et al. (2019) found that "the last simulated decade, 20002009, is approximately 1 degrees C warmer in West Africa in the ensemble accounting for human influences on climate, with more frequent heat and rainfall extremes". Referring to West Africa, Sarr (2012) highlights that observations already indicate an average increase in temperature of $0.2-0.8^{\circ} \mathrm{C}$ since the end of the 1970s (ECOWAS-SWAC et al., 2008); when projected, this increases to between 3.0 and $4.0^{\circ} \mathrm{C}$ between 1980/1999 and 2080/2099 (IPCC, 2007). Sultan et al. (2014) put that the "subset of bias-corrected climate models projects a mean warming of +2.8 degrees $C$ in the decades of 2031-2060 compared to a baseline of 1961-1990" in West Africa. Likewise, Olusegun et al. (2018) argue that "Widespread warming (1-3 degrees C) and drying (1-2 $\mathrm{mm} /$ day) is projected in the near future across most parts of West Africa all year round". Kima et al. (2015) show that "the annual minimum and maximum temperatures showed a statistically significant upward trend, with a rate of change of 0.20 degrees $C$ and 0.27 degrees C per decade" in BF over the period 1980-2012.

As for precipitation and rainfall, studies highlight their increasing variability across the region (Sidibe et al., 2019). Nevertheless, Klutse et al. (2018) point out that the "enhanced warming results in a reduction in mean rainfall across the region" in West Africa. Contrariwise, Bicher and Diedhiou (2018) found that "the recent increase in precipitation results principally from an increase in the number of wet days $(+10$ d compared to the normal) over the entire West African Sahel band, along with an increase in the precipitation intensity over the central part of the West African Sahel (+3 mm $d(-1))$ " (p. 155). In their analysis of the long-term annual trends of rainfall from 1980 to 2012 in BF, Kima et al. (2015) put that "within the period of study, the annual rainfall showed an upward trend, with high inter-annual variability and $818.9 \mathrm{~mm}$ of mean annual rainfall". It seems that the impacts of climate change on rainfall will vary across West Africa; Sultan et al. (2014) predict "a robust change in rainfall in West Africa with less rain in the Western part of the Sahel (Senegal, South-West Mali) and more rain in Central Sahel (Burkina Faso, South-West Niger)" by 2060.

One of the indicators of the changing climate in West Africa and Sahel is the increase of the frequency of extreme weather events such as droughts (Chaney et al., 2014; Haile, 2005; Klutse et al., 2018; Oguntunde et al., 2017; Traore \& Owiyo, 2013) and intensive rainfalls (Berthou et al., 2019; Bichet \& Diedhiou, 2018; Klutse et al., 2018). Climatic fluctuations also impact river catchments and streamflow (Andam-Akorful et al., 2017; Bhaduri et al., 201 1; Mahe et al., 2013; Oguntunde et al., 2017; Sidibe et al., 2019; Sossa et al., 2017) with implications for water 
resources availability as well as flood frequencies (Haile, 2005; Sidibe et al., 2019; Sossa et al., 2017; Sylla et al., 2015).

Other studies focus on the perception of climate change (Boansi et al., 2017, 2019; Callo-Concha, 2018; Fonta et al., 2015; Zampaligré et al., 2014). Boansi et al. (2019) argue that "Based on farmers' perception, it is found that drought, low rainfall, intense precipitation, flooding, erratic rainfall pattern, extremely high temperatures, delayed rains, and early cessation of rains are the major threats farmers face" (p. 355). However, referring to farmer perceptions on climate change in West Africa (Benin and Burkina Faso), Callo-Concha (2018) suggest that "responses regarding climate change perception and adaptation are frequently subjective, conjectural and inconsistent", which might imply that some caution is needed when dealing with them.

Some scholars report a phenomenon of 'greening' (Epule et al., 2014) or 'regreening' (Stith et al., 2016) in the Sahel region and link it to climate change. For instance, Epule et al. (2014) hypothesize that "the increase in $\mathrm{CO}$, might be responsible for the increase in greening and rainfall observed. This can be explained by an increased aerial fertilization effect of $\mathrm{CO}_{2}$ that triggers plant productivity and water management efficiency through reduced transpiration". Other authors point out a slight rainfall recovery over the Sahel which is concomitant with a climate warming in the region (Salack et al., 2016). Global warming also triggers hybrid rainy seasons in the Sahel, which represents a real challenge for rain-fed farming systems (Salack et al., 2016).

In this context of sometimes contradictory data, some scholars raised concerns regarding the accuracy and reliability of projections based on climate models (Berthou et al., 2019; Dale et al., 2017; Guan et al., 2017; Paeth, 2011; Ramirez-Villegas \& Challinor, 2012). For instance, Paeth (2011) put that "climate models tend to produce systematic errors, especially, in terms of rainfall and cloud processes, which are usually approximated by physical parameterizations" (p. 1321). Likewise, Ramirez-Villegas and Challinor (2012) argue that "Climate models were found inadequate for field-scale agricultural studies in West Africa and South Asia, as their ability to represent mean climates and climate variability was limited" (p. 26).

\section{Climate change mitigation and adaptation}

Most of the analysed documents deal with the adaptation of the Burkinabe agriculture to climate change (Table 5). However, many articles address simultaneously mitigation of and adaptation to climate change in agriculture. For instance, climate-smart agriculture (Abegunde et al., 2019; Makate, 2019; Prestele \& Verburg, 2020) does not only allow reducing GHG emissions but also making agriculture more climate-resilient. The analysis of adaptation and mitigation options is often preceded by referring to the impacts of climate change on agriculture in the country or the wider region (e.g. West Africa, Sahel, SSA). The literature shows that some initiatives and projects even seek the 'triple-wins' of development, adaptation and mitigation (Suckall et al., 2015).

\section{Agriculture and climate change mitigation}

Some of the selected papers deal with the assessment of GHG emissions from agriculture as well as strategies and options to reduce them. Other papers analyse how agriculture can be used to sequester carbon thus reducing the $\mathrm{CO}_{2}$ concentrations in the atmosphere. Referring to GHG emissions in SSA, Kim et al. (2016) put that "Carbon dioxide $\left(\mathrm{CO}_{2}\right)$ emissions were by far the largest contributor to GHG emissions and global warming potential (GWP) in SSA" (p. 4789) thus exceeding methane $\left(\mathrm{CH}_{4}\right)$ and nitrous oxide $\left(\mathrm{N}_{2} \mathrm{O}\right)$ emissions. Emissions are affected, among others, by crop residues and manure management, and fertilisation (Kim et al., 2016).

The management of soil organic matter is central in the responses to climate change. In this regard, Kamoni and Gicheru (2015) argue that "Increasing soil organic matter content can both improve soil fertility and reduce the impact of drought, improving adaptive capacity, making agriculture less vulnerable to climate change, while also sequestering carbon" (p. 307). Referring to conservation agriculture (CA), Powlson et al. (2016) put that "It is also claimed to mitigate climate change through soil carbon sequestration" (p. 164) and argue that "the mitigation potential, and other benefits, from crop diversification are frequently overlooked when considering CA and warrant greater attention" (p. 164). Indeed, Kamoni and Gicheru (2015) pinpoint that "Sustainable land management practices enhance carbon sequestration and sustain agricultural productivity, thus mitigating against climate change" (p. 307). Agroforestry (Luedeling \& Neufeldt, 2012; Mutuo et al., 2005; Olusegun et al., 2018) is also considered as a means to increase carbon sequestration and reduce GHG emissions. Mutuo et al. (2005) suggest that "Evidence is emerging that agroforestry systems are promising management practices to increase aboveground and soil $\mathrm{C}$ stocks and reduce soil degradation, as well as to mitigate greenhouse gas emissions" (p. 43). However, Dimobe et al. (2018) underline that the success of carbon sequestration projects, including those involving agro-forestry, lies in the "involvement of local populations in the selection of woody species [...] and information about the potential of these species to store carbon". Moreover, there are some doubts about whether carbon sequestration markets (cf. Clean Development Mechanism - CDM) benefit African low-income producers; for instance, Perez et al. (2007) argue that "while C payments may contribute to increasing rural incomes and promoting productivity enhancement practices, they may also expose resource users to additional social tensions and institutional risks" (p. 2). In this context, Ringius (2002) highlight the need for more studies on opportunities and challenges of soil carbon sequestration in Africa.

Different strategies are suggested to mitigate climate change. These include some controversial ones such as the use of genetically modified crops (GMCs). Indeed, Quintero and Cohen (2019) highlight that BF is one of countries that "could be the best contributors to the mitigation of the climate change by the reduction of their $\mathrm{CO}_{2}$ emission levels through GMCs" (p. 641). Furthermore, intensification (in crop production, animal production and mixed crop-livestock systems) is presented as one of the strategies to combine food security and climate change 
Table 5: Examples of documents addressing mitigation of and/or adaptation to climate change in the analysed scholarly literature

\begin{tabular}{|c|c|}
\hline Mitigation vs. Adaptation & References \\
\hline Mitigation & $\begin{array}{l}\text { Arthur and Baidoo (2011); Belem et al. (2011); Bennetzen et al. (2016); Bostick et al. (2007); Dimobe et al. (2018); } \\
\text { Doelman et al. (2018); Egbendewe (2018); Henderson et al. (2017); Hendrix and Glaser (2007); Kamoni and Gicheru } \\
\text { (2015); Luedeling and Neufeldt (2012); Ogundari et al. (2017); Perez et al. (2007); Quintero and Cohen (2019); Ringius } \\
\text { (2002); Torquebiau (2017); van Loon et al. (2019) }\end{array}$ \\
\hline Adaptation & $\begin{array}{l}\text { Abidoye and Odusola (2015); Amjath-Babu et al. (2016); Asafu-Adjaye (2014); Asare-Kyei et al. (2017); Barbier et al. } \\
\text { (2009); Belesova et al. (2019); Boansi et al. (2017); Bodin et al. (2016); Brockhaus et al. (2012); Bryan et al. (2018); } \\
\text { Buhaug et al. (2015); Bunclark et al. (2018); Busby et al. (2014); Callo-Concha (2016); Callo-Concha (2018); Calzadilla } \\
\text { et al. (2013); Chen et al. (2018); Choptiany et al. (2017); Cooper et al. (2008); D'haen et al. (2014); Di Leo et al. } \\
\text { (2016); Dixon and Stringer (2015); Douxchamps et al. (2016); Fonta et al. (2015); Gahi et al. (2015); Garcia de Jalon } \\
\text { et al. (2018); Gray and Wise (2016); Guan et al. (2017); Haile (2005); Haussmann et al. (2012); Ingram et al. (2002); } \\
\text { Jarvis et al. (2012); Johnson and Brown (2014); Jones and Thornton (2009); Kalame et al. (2011); Kima et al. (2014); } \\
\text { Kima et al. (2015); Kniveton et al. (2012); Lay et al. (2009); Lebel et al. (2015); Lobell et al. (2008); López-Carr et al. } \\
\text { (2014); McPeak (2017); Mertz (2011); Mertz et al. (2010); Mertz et al. (2016); Naumann et al. (2014); Palazzo et al. } \\
\text { (2017); Parkes et al. (2018); Pironon et al. (2019); Ramin and McMichael (2009); Rasmussen (2018); Rasmussen et al. } \\
\text { (2014); Rigolot et al. (2017); Rippke et al. (2016); Roncoli et al. (2001); Rosenthal and Ort (2012); Salack et al. (2015); } \\
\text { Sanfo et al. (2017); Schlenker and Lobell (2010); Seo et al. (2009); Serdeczny et al. (2017); Sheffield et al. (2014); } \\
\text { Sidibé et al. (2018); Siebert (2016); Sissoko et al. (2011); Sonwa et al. (2017); Sorgho et al. (2016); Tankari (2020); } \\
\text { Tesfaye et al. (2015); Thornton and Herrero (2014); Thornton and Herrero (2015); Thornton et al. (2011); Traoré et al. } \\
\text { (2011); van Oort and Zwart (2018); van Wesenbeeck et al. (2016); vom Brocke et al. (2014); von Uexkull (2014); Waha } \\
\text { et al. (2013); Waha et al. (2016); Waongo et al. (2015); West et al. (2008); Wood et al. (2014); Zampaligré and Fuchs } \\
\text { (2019); Zampaligré et al. (2014); Zidouemba (2017); Zorom et al. (2010); Zorom et al. (2013) }\end{array}$ \\
\hline Mitigation and adaptation & $\begin{array}{l}\text { Bayala et al. (2014); Corbeels et al. (2014); Coulibaly et al. (2014); Descheemaeker et al. (2016); Fanzo et al. (2018); } \\
\text { Garrity et al. (2010); Hasegawa et al. (2018); Henderson et al. (2016); Lahmar et al. (2012); Lobell et al. (2013); } \\
\text { Prestele and Verburg (2020); Richardson et al. (2018); Steward et al. (2018); Tittonell et al. (2012) }\end{array}$ \\
\hline
\end{tabular}

mitigation (Ayantunde et al., 2020; Descheemaeker et al., 2016; van Loon et al., 2019). Nevertheless, referring to cereal cropping in 10 countries in SSA (i.e. Burkina Faso, Ethiopia, Ghana, Kenya, Mali, Niger, Nigeria, Tanzania, Uganda and Zambia), van Loon et al. (2019) conclude that "intensification scenarios are clearly superior to expansion scenarios in terms of climate change mitigation" (p. 3720) but point out that "irrespective of intensification or extensification, GHG emissions of the 10 countries jointly are at least 50\% higher in 2050 than in 2015. Intensification will come, depending on the nutrient use efficiency achieved, with large increases in nutrient inputs and associated GHGemissions" (p. 3720). Furthermore, cropland intensification threatens biodiversity in Sub-Saharan Africa (Zabel et al., 2019). This is one of the environmental costs of mitigation, but also economic costs of abating GHG emissions (Henderson et al., 2017; Lobell et al., 2013; Ringius, 2002) as well as social ones (e.g. food security) should be considered for an accurate evaluation of mitigation strategies and options in BF and SSA at large.

\section{Impacts of climate change on Burkinabe agriculture}

Climate change can have different and far-reaching impacts on agriculture and rural populations in SSA. Indeed, Zougmore et al. (2018) suggest that "[...] without appropriate interventions, climate change and variability will affect agricultural yields, food security and add to the presently unacceptable levels of poverty in sub-Saharan Africa". Some papers analyse the impacts of climate change on agricultural production and yields (Lokonon et al., 2019; Serpantié et al., 2019; Sultan, Defrance, et al., 2019). Analyses regard different crops such as cassava (Egbebiyi, Crespo, et al., 2019; Egbebiyi, Lennard, et al., 2019; Jarvis et al., 2012; Rosenthal \& Ort, 2012), maize (Kamali et al., 2018, 2019; Nelimor et al., 2019; Parkes et al., 2018; Ugbaje et al., 2019), mango (Egbebiyi, Crespo, et al., 2019), millet (Egbebiyi, Crespo, et al., 2019; Faye et al., 2018;
Pironon et al., 2019; Sultan et al., 2013; Sultan, Defrance, et al., 2019) and sorghum (Akinseye et al., 2020; Hadebe et al., 2017; Sultan et al., 2014; Sultan, Defrance, et al., 2019; vom Brocke et al., 2014). Sultan and Gaetani (2016) highlight that "a robust evidence of yield loss in West Africa emerges. This yield loss is mainly driven by increased mean temperature while potential wetter or drier conditions as well as elevated $\mathrm{CO}_{2}$ concentrations can modulate this effect". Lokonon et al. (2019) show that "paddy rice, oilseeds, sugarcane, cocoa, coffee, and sesame production could experience a decline under both moderate and harsh climate conditions" in the Economic Community of West African States (ECOWAS). Referring to about 1 degree C warming in West Africa in the decade 2000-2009, Sultan et al. (2019) posit that "These altered climate conditions have led to regional average yield reductions of 10-20\% for millet and 5-15\% for sorghum". Production loss also implies the loss of income for farmers and revenues for countries. Sultan et al. (2019) found that "the average annual production losses across West Africa in 2000-2009 associated with historical climate change, relative to a non-warming counterfactual condition (that is, pre-industrial climate), accounted for 2.33-4.02 billion USD for millet and 0.73-2.17 billion USD for sorghum”. However, other scholars, argue that the so-called 'carbon fertilisation' may offset the impact of global warming on crop yields. Indeed, Roudier et al. (2011) put that "results highlight the pivotal role that the carbon fertilization effect may have on the sign and amplitude of change in crop yields" (p. 1073).

Referring to West Africa, Sarr (2012) points out that "Of greater concern, however, is the late onset, early cessation dates of rainfall and reduction of length of growing period (LGP) which are now locally negatively impacting agriculture in the region. Furthermore, projections indicate a $20 \%$ reduction of LGP in 2050" (p. 108). Climate change is also expected to affect crop suitability in BF as well as West Africa at large (Egbebiyi, 
Crespo, et al., 2019; Egbebiyi, Lennard, et al., 2019; Ugbaje et al., 2019). Referring to the three agro-ecological zones of West Africa (viz. Guinea, Savanna and Sahel), Egbebiyi et al. (2019) point out that "warming is projected to constrain crop growth suitability for cassava and pineapple in the Guinea zone". Also the suitability for other crops (e.g. maize, mango, pearl millet) will be affected by the changing climate in the region. Indeed, Ugbaje et al. (2019) show that, regardless of the trajectory of future rainfall projection, temperature projection will decrease suitability for rain-fed maize in West African region by 2080 .

Another topic that is related to the impacts of climate change on agricultural production is food security. Indeed, many scholars (Fanzo et al., 2018; Hadebe et al., 2017; Haile, 2005; Hasegawa et al., 2018; Niles \& Brown, 2017; Richardson et al., 2018; Rigolot et al., 2017; Sultan, Defrance, et al., 2019; Tesfaye et al., 2015) highlight the detrimental effects of climate change on the food security of the population in BF and Sahel at large. Most of the analysed papers focus on the damages of climate change to agriculture thus reducing food availability; however, Hasegawa et al. (2018) highlight that also stringent climate change mitigation measures can increase food insecurity risk in Sub-Saharan Africa. Therefore, one pressing challenge is how to reconcile socio-economic development (including the achievement of food security) and environmental conservation (including climate change mitigation) in BF and Sub-Saharan Africa as a whole (Rudi et al., 2012).

The impacts of food insecurity and malnutrition caused by production decrease due to global warming might be particularly severe among vulnerable groups such as children (Belesova et al., 2019; Sorgho et al., 2016) and women (Bryan et al., 2018; Huyer, 2016). Indeed, Belesova et al. (2019) show that low annual crop yields in the scenario of 1.5 degrees $\mathrm{C}$ warmer climate in 2100 would increase child mortality in a subsistence farming population of Nouna district (Kossi Province, western Burkina Faso). Moreover, evidence shows that the impacts of climate change are higher on smallholders (García de Jalón et al., 2018; Henderson et al., 2016; Waha et al., 2016; Williams et al., 2018; Wood et al., 2014). In this regard, Williams et al. (2018) put that "The impacts of changing climate on agriculture have consequences on livelihoods and food security. Smallholder farmers, who have heterogeneous farming systems and limited resources, compounded with multiple risks, are greatly affected".

Climate change is also expected to affect the incidence of pests and diseases (Botha et al., 2020; Jarvis et al., 2012; Sileshi et al., 2019; Wilcox et al., 2019) with increasing damages on crops and animals. Botha et al. (2020) suggest that “[...] median temperature increases are associated with increased pest pressure and changes in migratory patterns. These factors will result in significantly more pest invasions and an increased need for innovative insect management practices". Likewise, Jarvis et al. (2012) show that the geographic distribution as well as the severity of cassava pests and diseases (e.g. whitefly, cassava mosaic disease, cassava mealybug, brown streak disease) are projected to change.
Another impact of climate change is the increase in conflicts (Buhaug et al., 2015; Döring, 2020; Hendrix \& Glaser, 2007; Jun, 2017; Mertz et al., 2016; von Uexkull, 2014; Witmer et al., 2017) mainly on natural resources such as water (both surface water and groundwater) and pastures/rangelands. For instance, Jun (2017) found that "between 1970 and 2012 in sub-Saharan Africa, a high temperature during maize growing season reduced the crop's yield, which in turn increased the incidence of civil conflict and [...] future expected warming is expected to increase civil conflict incidence by 33\% in the period 2031-2050, and by 100\% in the period 2081-3010, compared to levels between 1981 and 2000" (p. 183). Meanwhile, von Uexkull et al. (2016) conclude that "for agriculturally dependent groups as well as politically excluded groups in very poor countries, a local drought is found to increase the likelihood of sustained violence" (p. 12391).

While estimates of climate change impacts rely on the use of different models, climate modelling is more and more criticised (Ackerman \& Munitz, 2016), which means that some caution is needed when using these generated data. Indeed, it should be pointed out that the assessments of the impacts of climate change on agriculture are subject to considerable model uncertainties and deficiencies (Druyan, 2011; Müller, 2013; Muller et al., 2011). In this respect, Müller (2013) assume that "There are multiple reasons for differences in projections, including uncertainties in greenhouse gas emissions and patterns of climate change; assumptions on future management, aggregation, and spatial extent; and methodological differences" (p. 395).

\section{Adaptation of Burkinabe agriculture to climate change}

The literature shows that $\mathrm{BF}$ is highly vulnerable to climate change (Busby et al., 2014). Indeed, Busby et al. (2014) identify the country as a hotspot of climate change vulnerability in Africa and the situation is expected to worsen in the future; Indeed, they put that "For the late $20^{\text {th }}$ century, this mapping process reveals the most vulnerable areas are concentrated in Chad, the Democratic Republic of the Congo, Niger, Somalia, Sudan, and South Sudan, with pockets in Burkina Faso, Ethiopia, Guinea, Mauritania, and Sierra Leone. The mid $21^{\text {st }}$ century projection shows more extensive vulnerability throughout the Sahel, including Burkina Faso, Chad, Mali, northern Nigeria, Niger, and across Sudan" (p. 717). This makes vital the adoption of climate change adaptation measures.

Most of the selected articles deal with climate change adaptation in crop production while animal production and agro-forestry are often overlooked. This is corroborated by the findings of Gautier et al. (2016) who put that "The literature on responses to drought focuses on agricultural and individual responses, while diversification, migration, and tree-based or livestock-based responses are less frequently addressed" (p. 666). Some papers focus on the resilience and adaptation of smallholders to climate change (García de Jalón et al., 2018; Henderson et al., 2016; Waha et al., 2016; Williams et al., 2018; Wood et al., 2014) while others deal with pastoralists or agro-pastoralists (Choptiany et al., 2017; Rasmussen et al., 2014, 2015; Zampaligré et al., 2014). Other papers have a more specific focus such as women (Bryan 
et al., 2018; Huyer, 2016). As for climate change adaptation in West African fisheries, Katikiro and Macusi (2012) suggest that "Diversifying fish sources may enable the region's rural households to cope and adapt to climate change impacts" (p. 83).

Akinseye et al. (2020) argue that "Climate variability and change will have far reaching consequences for smallholder farmers in subSaharan Africa, the majority of whom depend on agriculture for their livelihoods". Azzarri and Signorelli (2020) show that there is a strong correlation between climatic conditions, and climate change (cf. rain/flood and heat shocks), and household welfare/ poverty in Sub-Saharan Africa. Gautier et al. (2016) put that "in West Africa, climate variations and droughts have always affected livelihoods but have also triggered adaptation strategies" (p. 666). Indeed, different strategies are adopted by agricultural and rural households to adapt to climate change. These strategies range from changes in the cropping systems, diversification of livelihoods to migration. In this context, Sissoko et al. (2011) put that "To cope with the difficult climatic situation, farm households have developed a range of strategies including selling of animals and on-farm diversification or specialization" (p. 119). Roncoli et al. (2001) argue that "Livelihood diversification, encompassing migration, non-farm work and social support networks, in addition to livestock production, is shown to be a critical dimension of adaptation" (p. 119). Muchuru and Nhamo (2019) enumerate among the categories of adaptation measures in the African crop sector promoted by governments "conservation agriculture; water, irrigation and flood management; crop diversification; inputs and subsidies; disease and pest management; and weatherbased index insurance". Partey et al. (2018) found "agroforestry (farmer-managed natural regenerations), soil and water conservation technologies (zai, half-moon, tie/contour ridges, conservation agriculture) and [...] climate information services as highly valued promising options for climate change adaptation and risk management in West Africa" (p. 285). The concept of climate-smart agriculture is central in adaptation strategies and measures. In this context, Zougmore et al. (2018) put that "the past decades have seen the development and promotion of climate-smart agriculture innovations such as the use of high yielding drought tolerant crop varieties, climate information services, agricultural insurance, agroforestry, water harvesting techniques, integrated soil fertility management practices, etc.".

As for changes in the cropping system, Boansi et al. (2019) argue that "To moderate harm from anticipated weather extremes, farmers need to adjust their cropping calendar, adopt appropriate crop varieties, and implement soil and water management practices" (p. 355). There are broadly two distinct strategies that consists in either keeping the same crop(s) while changing the cropping cycle and crop management, or introducing new crops or cultivars that are more adapted to climate change. Referring to the literature on climate change in West Africa, Sultan and Gaetani (2016) argue that "Potential for adaptation is illustrated for major crops in West Africa through a selection of studies based on process-based crop models to adjust cropping systems (change in varieties, sowing dates and density, irrigation, fertilizer management) to future climate". Changes in the cropping system encompass varying the sowing/planting time (Egbebiyi, Crespo, et al., 2019; Egbebiyi, Lennard, et al., 2019;
Waha, Müller, Bondeau, et al., 2013). However, Guan et al. (2017) assess five adaptation options for sorghum "(i) late sowing, (ii) intensification of seeding density and fertilizer use, (iii) increasing cultivars' thermal time requirement, (iv) water harvesting, and $(v)$ increasing resilience to heat stress during the flowering period" (p. 29l) and point out that they are not effective in reducing the impacts of climate change on sorghum production in West Africa. Referring to farmers in eastern Ghana and south-western BF, Boansi et al. (2019) argue that "Due to recent changes in onset of rains and length of the rainy season, some farmers have either resorted to early planting of drought-hardy crops, late planting of drought-sensitive crops, or spreading of planting across the first 3 months of the season to moderate harm" (p. 355).

Another adaptation strategy consists in the adoption of 'climate smart crops' (Pushpalatha \& Gangadharan, 2020) that's to say those crops (or cultivars) that are more adapted to harsh conditions and can withstand changing climate (e.g. drought). Examples of these crops that are analysed in the literature include cassava (Egbebiyi, Lennard, et al., 2019; Pushpalatha \& Gangadharan, 2020), sorghum (Akinseye et al., 2020) and maize (Nelimor et al., 2019). For instance, Pushpalatha and Gangadharan (2020) highlight the resilience of cassava to changing climate and put that "Studies indicate cassava can tolerate a temperature level of up to 40 degrees C [...] Cassava has also an inbuilt mechanism to cope with water scarcity by leaf drooping [...] Studies also indicate a strong positive influence of elevated $\mathrm{CO}_{2}$ of up to 700 ppm on the rate of photosynthesis and yield of cassava. Elevated $\mathrm{CO}_{2}$ enhances the resilience of cassava to water stress and salinity. Similarly, the combined effect of elevated $\mathrm{CO}_{2}$ and higher temperatures also increases the yield attributes of cassava". In this context, there is an ongoing debate on the benefits of genetically modified crops in terms of climate change mitigation and adaptation (Quintero \& Cohen, 2019).

An effective adaptation to climate change also implies fully exploiting the potential of ecosystem services for climate change resilience in rural as well as peri-urban areas (Mngumi, 2020). Indeed, Mngumi (2020) argue that "the potential for climate change resilience of well-managed peri-urban ecosystem services includes reducing the physical exposure of peri-urban areas to floods and droughts and minimizing climate change risks through increased socio-economic resilience to hazard impacts and provision of the carbon sequestration function".

Resilience to drought is a central theme in the literature on climate change adaptation in the Sahel (Hadebe et al., 2017; Kamali et al., 2018, 2019; Naumann et al., 2014; Nelimor et al., 2019; Sidibé et al., 2018). Kamali et al. (2019) suggest "improving adaptations to drought through investing in infrastructure, improving fertilizer distribution, and fostering economic development would contribute to drought resilience". In this context, farmers in BF, as well as in the whole West Africa, adopted many water-harvesting techniques (e.g. stone rows, zai, half-moon) to mitigate the impacts of drought (Zouré et al., 2019). Roncoli et al. (2001) point out that "Affordable grain, locally adapted seed varieties, labor saving technology and flexible credit are among the most needed inputs" (p. 119) to cope with drought in BF. 
Irrigation is widely mentioned as a strategy to mitigate the vulnerability of rain-fed agriculture to climate change (AmjathBabu et al., 2016; Asafu-Adjaye, 2014; Cobbing \& Hiller, 2019; Sylla, Pal, et al., 2018; Ward et al., 2014; Yamegueu et al., 2019; Zidouemba, 2017). Nevertheless, increasing recourse to groundwater for irrigation and other uses (cf. pastoralism) may trigger communal violence (Döring, 2020). Indeed, Döring (2020) shows that "lacking access to groundwater is associated with a higher risk of communal violence. Further, the effect of groundwater access on communal violence is conditioned by precipitation levels as well as population density". Irrigation is sometimes discussed in the analysed literature together with rainwater harvesting techniques (Biazin et al., 2012; Bunclark et al., 2018; Guan et al., 2017; Lebel et al., 2015; Zampaligré et al., 2014).

As for the relationship between crop diversification and climate change adaptation, Pironon et al. (2019) suggest that "Crop insecurity increases over time and with rising GHG emissions, but the potential for using agrobiodiversity for resilience is less altered. Climate change will therefore affect sub-Saharan agriculture but agrobiodiversity can provide resilient solutions in the short and medium term" (p. 758). Meanwhile, in their analysis of the effects of climate stress on maize-based conservation agriculture systems, Steward et al. (2018) conclude that "crop diversification did not notably improve conservation agriculture performance, but did increase its stability with heat stress" (p. 194).

Livelihood diversification in another strategy for adaptation to climate change among agricultural households (Asafu-Adjaye, 2014; Lay et al., 2009; Nielsen \& Reenberg, 2010; Sissoko et al., 2011; Tankari, 2020; Zorom et al., 2013). Indeed, many rural households rely more and more on non-farm activities for gaining their livelihoods and ensuring their food security (D’haen et al., 2014; Lay et al., 2009; Tankari, 2020). For instance, Tankari (2020) conclude that "Operating a nonfarm activity may therefore be a strategy to cope with the effects of rainfall variability among farm households in Burkina Faso". Chuku and Okoye (2009) identify four broad strategies to reduce vulnerability and increase resilience among farmers in SSA namely "income and asset management strategies, farm production strategies, government programmes and support strategies and technological development strategies" (p. 1524). Therefore, diversification of income-generating activities is considered as one of the risk management strategies.

Migration is considered as a further adaptation, coping strategy (Defrance et al., 2017; Gray \& Wise, 2016; Kniveton et al., 2012; Roncoli et al., 2001; Sanfo et al., 2017; Zampaligré et al., 2014; Zorom et al., 2010). Defrance et al. (2017) estimate that "without any adaptation measures, tens to hundreds million people could be forced to leave the Sahel by the end of this century" (p. 6533). Referring to adaptation strategies of agropastoralists and pastoralists across BF, Zampaligré et al. (2014) put that "Strategies of pastoralists included seasonal, annual and permanent migration and taking up of cereal cropping" (p. 769).

Different factors affect the adoption of climate change adaptation strategies by farmers and rural populations (García de Jalón et al.,
2016, 2018; Zampaligré \& Fuchs, 2019). In their analysis of the drivers of adaptation to climate change in African farms, Garcia de Jalon et al. (2016) found that the "[...] common factors can be grouped into seven components, that is human capital, financial resources, infrastructure and technology, social interaction and governance, food security, dependence on agriculture and attitudes towards the environment" (p. 779). Likewise, in their study on the effects of livelihoods assets/capitals (natural, physical, financial, human, social), that constitute 'adaptive capacity', on the adoption of adaptation strategies by smallholders in SSA, Garcia de Jalon et al. (2018) put that "Human and social capital both displayed a positive and significant effect on the uptake of most adaptation practices. This finding suggests that the effect of less tangible kinds of capital such as knowledge, individual perceptions, farmers' networks and access to information may be stronger than normally assumed" (p. 38). Meanwhile, Zampaligré and Fuchs (2019) analyse the determinants of adopting climate-smart adaptation practices in the Sahelian agro-pastoral systems and conclude that "a few assets were found to contribute significantly to the decision to adopt the assessed adaption practices. These include the possession of household and farm assets and equipment, membership in associations and assistance from government, farming experience of the household head, access to credit, as well as ownership and size of farmland".

Governance and institutions play a central role in determining the effectiveness of adaptation strategies (Brockhaus et al., 2012; García de Jalón et al., 2016; Makate, 2019). Indeed, referring to factors that explain the adoption of climate change adaptation strategies at farm level, Garcia de Jalon et al. (2016) conclude that "adoption is associated predominantly with governance, civil rights, financial resources and education" (p. 779). Moreover, Makate (2019) argues that "enhancing the role of local institutions (LI) and incorporating indigenous knowledge (IK) in climate change adaptation planning can improve adoption and scaling success of climate-smart agriculture innovations" thus calling for an active engagement of local communities and indigenous stakeholder institutions in the design, planning and implementation of climate adaptation activities. In this context, initiatives such as the "4 per Thousand" and "Adapting African Agriculture", two initiatives adopted at the COP21 in Paris and the COP22 in Marrakesh (Morocco), can contribute to climate change mitigation and adaptation of African agriculture (Lal, 2019). Moreover, increasing attention has been devoted over the last decades to the mainstreaming of CSA into agricultural development plans as well as regional and national climate change adaptation policies and plans (Zougmoré et al., 2018). Referring to the National Adaptation Programme of Action (NAPA) in BF, Kalame et al. (2011) point out that agriculture, water resources and forestry are priority sectors in the NAPA. They assume that "Factors determining the success of a NAPA are the level of funding, effectiveness of the coordination and implementation of the NAPA, and the importance decision makers give to adaptation" (p. 535) and conclude that "ecosystem-based approaches to adaptation can be used to enhance the resilience of communities and ecosystems" (p. 535).

Anyway, an effective adaptation to climate change implies a timely and cost-effective access to climate information services 
that meet the users' needs (Carr et al., 2020; Chen et al., 2018; Vaughan et al., 2019; Wood et al., 2014; Zampaligré \& Fuchs, 2019). For instance, Wood et al. (2014) found that "access to weather information, assets, and participation in social institutions are associated with households that have reported making farming changes" (p. 163) in their study of smallholder adaptation strategies across SSA. In this context, access to extension services is an important determinant of adoption of climate-smart practices (Abegunde et al., 2019; Ayantunde et al., 2020; Boansi et al., 2017; Callo-Concha, 2018; Zampaligré \& Fuchs, 2019). Referring to Sub-Saharan Africa (SSA), Nkiaka et al. (2019) show that "greater capacity building of personnel working for National Meteorological and Hydrological Services and Agricultural Extension staff and reinforcing and sustaining collaboration between different stakeholders (climate scientists, hydrologists, extension workers, farmers and other user groups), are essential factors for improving the uptake and utility of weather and climate services to enhance resilience to climate shocks in SSA". Likewise, Boansi et al. (2017) recommend that "To enhance farmers' adaptive capacity, policy makers and various stakeholders need to contribute towards improving farmers' access to credit, markets, and extension services" (p. 1).

Different financial products and services, based on climate information, have been promoted to adapt to climate change in developing countries. These instruments include insurance products such as "index insurance" (Siebert, 2016). However, also access to credit (Boansi et al., 2017; Jahel et al., 2017; Zampaligré \& Fuchs, 2019) determine the level of investment in climate change adaptation and, consequently, their effectiveness and sustainability.

While most of the papers use household or farm as a unit of analysis without any disaggregation, others address gender issues (Bryan et al., 2018; Huyer, 2016). In this respect, Huyer (2016) argues that "Technologies to support resilience and adaptation to climate change by smallholder farmers can promote women's empowerment and the transformation of gender relations in addition to sustainably increasing agricultural production. But this will only happen if they are implemented in a framework of mutually reinforcing resources, women's control of assets, equitable decision making between women and men, and strengthened capacity" (p. 105).

Evidence shows that not only the types of adaptation strategies but also the timing is important to consider. In this respect, Rippke et al. (2016) envisage "three overlapping adaptation phases to enable projected transformational changes: an incremental adaptation phase focused on improvements to crops and management, a preparatory phase that establishes appropriate policies and enabling environments, and a transformational adaptation phase in which farmers substitute crops, explore alternative livelihoods strategies, or relocate" (p. 605).

\section{CONCLUSIONS}

This paper represents the first comprehensive review on the multifaceted relationships between climate change and agriculture in Burkina Faso. The review shows an increasing academic interest in the nexus between climate change and agriculture in BF and beyond (viz. West Africa, Sahel, SubSaharan Africa). The analysed literature focuses on crops (either alone or in mixed crop-livestock systems), while animal husbandry and, especially, fisheries are often overlooked. Likewise, most of the analysed documents deal with the adaptation to climate change by the Burkinabe farmers, herders, pastoralists and the rural populations in general. Nevertheless, many articles - such as those dealing with climate-smart agriculture - address simultaneously climate change mitigation and adaptation.

Evidence from the literature shows that Burkina Faso is experiencing climate change as characterized by warming, monsoonal precipitation recovery, and an increase in the occurrence of climate extremes. These climate tendencies are projected to continue although uncertainties affect climate simulations, especially regarding precipitation. A robust evidence of yield loss in BF, mainly driven by warming and increase in air temperature, emerges from the analysed literature. The negative impact of CC on crop yields results mainly from temperatures, for which climate models project an increase that is much larger with respect to changes in precipitation, which are still uncertain in climate projections. However, some scholars argue that elevated $\mathrm{CO}_{2}$ concentrations (cf. "carbon fertilisation') can help modulate yield loss. Yield losses and consequent decrease of agricultural production can have farreaching effects in terms of food security and rural livelihoods in the country. In this context, different strategies are used by farmers to adapt to climate change; the categories of adaptation options include conservation agriculture and climate-smart agriculture, irrigation, crop diversification, increased inputs use and intensification, livelihoods diversification and migration. However, most of the analysed literature deals with adaptation to climate change in crop production while animal production and agro-forestry are often overlooked. Furthermore, the focus is mainly on agricultural and individual responses, while livelihoods strategies, such as diversification and migration, are less frequently addressed. As for adaptation in crop production, most case studies focus on potential for adaptation and adjustment of cropping systems (e.g. changing sowing/ planting dates, sowing density, varieties, fertilizer management, irrigation) for major staple crops (e.g. millet, sorghum, maize). As for climate change adaptation in Burkinabe agriculture, more research is needed on the effectiveness of the different adaptation strategies and measures as well as the effects of the synergistic or antagonistic interactions between them. Furthermore, more attention should be devoted by researchers and scholars to community responses as well as tree-based and livestock-based ones. Another topic that deserves more emphasis in the research field is the contribution of ecosystem services to the resilience of rural communities in the face of the changing climate in $\mathrm{BF}$ and beyond (cf. West Africa, Sahel). It is also important to pay attention to the timing of the different adaptation strategies within adaptation phases to enable successful, smooth transformational changes in the Burkinabe agriculture. 
All in all, it is crucial to devote much more attention to the dual relation between climate change and agriculture in order to contribute to the achievement of the SDGs in BF. In this respect, more emphasis should be put on approaches that deliver mitigation, adaptation and development co-benefits in rural areas of BF. By improving the understanding of the impacts of climate change on agriculture and rural livelihoods as well as the responses of Burkinabe populations, this paper provides valuable insights to researchers and decision makers alike in order both to refine and make more impactful research on climate change in $\mathrm{BF}$ in particular and West Africa in general and to inform policies aimed at climate change mitigation and/or adaptation.

\section{ACKNOWLEDGEMENTS}

This work was carried out within the project SUSTLIVES (SUSTaining and improving local crop patrimony in Burkina Faso and Niger for better LIVes and EcoSystems) of the DeSIRA initiative (Development Smart Innovation through Research in Agriculture) financed by the European Union.

\section{CONFLICT OF INTEREST}

The author declares that he has no conflict of interest.

\section{REFERENCES}

Abdulai, A. (2018). Simon Brand Memorial Address. Agrekon, 57(1), 28-39. https://doi.org/10.1080/03031853.2018.1440246

Abegunde, V. O., Sibanda, M., \& Obi, A. (2019). The Dynamics of Climate Change Adaptation in Sub-Saharan Africa: A Review of Climate-Smart Agriculture among Small-Scale Farmers. Climate, 7(11), 132. https:// doi.org/10.3390/cli7110132

Abidoye, B. O., \& Odusola, A. F. (2015). Climate Change and Economic Growth in Africa: An Econometric Analysis. Journal of African Economies, 24(2), 277-301. https://doi.org/10.1093/jae/eju033

Ackerman, F., \& Munitz, C. (2016). A critique of climate damage modeling: Carbon fertilization, adaptation, and the limits of FUND. Energy Research \& Social Science, 12, 62-67. https://doi.org/10.1016/j. erss.2015.11.008

Adhikari, U., Nejadhashemi, A. P., \& Woznicki, S. A. (2015). Climate change and eastern Africa: a review of impact on major crops. Food and Energy Security, 4(2), 110-132. https://doi.org/10.1002/fes3.61

Adnew Degefu, M., Assen, M., Satyal, P., \& Budds, J. (2019). Villagization and access to water resources in the Middle Awash Valley of Ethiopia: implications for climate change adaptation. Climate and Development, 1-12. https://doi.org/10.1080/17565529.2019.1701973

Agrawal, A., Wollenberg, E., \& Persha, L. (2014). Governing agricultureforest landscapes to achieve climate change mitigation. Global Environmental Change, 29, 270-280. https://doi.org/10.1016/j. gloenvcha.2014.10.001

Ahmed, K. F., Wang, G., You, L., \& Yu, M. (2016). Potential impact of climate and socioeconomic changes on future agricultural land use in West Africa. Earth System Dynamics, 7(1), 151-165. https://doi. org/10.5194/esd-7-151-2016

Ahmed, K. F., Wang, G., Yu, M., Koo, J., \& You, L. (2015). Potential impact of climate change on cereal crop yield in West Africa. Climatic Change, 133(2), 321-334. https://doi.org/10.1007/s10584-015-1462-7

Akinbile, C. O., Akinlade, G. M., \& Abolude, A. T. (2015). Trend analysis in climatic variables and impacts on rice yield in Nigeria. Journal of Water and Climate Change, 6(3), 534-543. https://doi.org/10.2166/ wcc. 2015.044

Akinseye, F. M., Ajeigbe, H. A., Traore, P. C. S., Agele, S. O., Zemadim, B., \& Whitbread, A. (2020). Improving sorghum productivity under changing climatic conditions: A modelling approach. Field Crops Research, 246, 107685. https://doi.org/10.1016/j.fcr.2019.107685
Amadu, F. O., Miller, D. C., \& McNamara, P. E. (2020). Agroforestry as a pathway to agricultural yield impacts in climate-smart agriculture investments: Evidence from southern Malawi. Ecological Economics, 167, 106443. https://doi.org/10.1016/j.ecolecon.2019.106443

Amjath-Babu, T. S., Krupnik, T. J., Kaechele, H., Aravindakshan, S., \& Sietz, D. (2016). Transitioning to groundwater irrigated intensified agriculture in Sub-Saharan Africa: An indicator based assessment. Agricultural Water Management, 168, 125-135. https://doi.org/10.1016/j. agwat.2016.01.016

Andam-Akorful, S. A., Ferreira, V. G., Ndehedehe, C. E., \& Quaye-Ballard, J. A. (2017). An investigation into the freshwater variability in West Africa during 1979-2010. International Journal of Climatology, 37, 333-349. https://doi.org/10.1002/joc.5006

Andrieu, N., Sogoba, B., Zougmore, R., Howland, F., Samake, O., BonillaFindji, O., Lizarazo, M., Nowak, A., Dembele, C., \& Corner-Dolloff, C. (2017). Prioritizing investments for climate-smart agriculture: Lessons learned from Mali. Agricultural Systems, 154, 13-24. https://doi. org/10.1016/j.agsy.2017.02.008

Aniah, P., Kaunza-Nu-Dem, M. K., \& Ayembilla, J. A. (2019). Smallholder farmers' livelihood adaptation to climate variability and ecological changes in the savanna agro ecological zone of Ghana. Heliyon, 5(4), e01492. https://doi.org/10.1016/j.heliyon.2019.e01492

Antwi-Agyei, P., Stringer, L. C., \& Dougill, A. J. (2014). Livelihood adaptations to climate variability: insights from farming households in Ghana. Regional Environmental Change, 14(4), 1615-1626. https://doi. org/10.1007/s10113-014-0597-9

Arndt, C., Robinson, S., \& Willenbockel, D. (2011). Ethiopia's growth prospects in a changing climate: A stochastic general equilibrium approach. Global Environmental Change, 21(2), 701-710. https://doi. org/10.1016/j.gloenvcha.2010.11.004

Arthur, R., \& Baidoo, M. F. (2011). Harnessing methane generated from livestock manure in Ghana, Nigeria, Mali and Burkina Faso. Biomass and Bioenergy, 35(11), 4648-4656. https://doi.org/10.1016/j. biombioe.2011.09.009

Asafu-Adjaye, J. (2014). The Economic Impacts of Climate Change on Agriculture in Africa. Journal of African Economies, 23(S2), ii17-ii49. https://doi.org/10.1093/jae/eju011

Asare-Kyei, D., Renaud, F. G., Kloos, J., Walz, Y., \& Rhyner, J. (2017) Development and validation of risk profiles of West African rural communities facing multiple natural hazards. PLoS One, 12(3), e0171921. https://doi.org/10.1371/journal.pone.0171921

Asfaw, S., Scognamillo, A., Caprera, G. Di, Sitko, N., \& Ignaciuk, A. (2019). Heterogeneous impact of livelihood diversification on household welfare: Cross-country evidence from Sub-Saharan Africa. World Development, 117, 278-295. https://doi.org/10.1016/j. worlddev.2019.01.017

Ayanlade, A., Radeny, M., Morton, J. F., \& Muchaba, T. (2018). Rainfall variability and drought characteristics in two agro-climatic zones: An assessment of climate change challenges in Africa. Science of the Total Environment, 630, 728-737. https://doi.org/10.1016/j. scitotenv.2018.02.196

Ayantunde, A. A., Oluwatosin, B. O., Yameogo, V., \& van Wijk, M. (2020). Perceived benefits, constraints and determinants of sustainable intensification of mixed crop and livestock systems in the Sahelian zone of Burkina Faso. International Journal of Agricultural Sustainability, 18(1), 84-98. https://doi.org/10.1080/14735903.201 9.1698494

Azzarri, C., \& Signorelli, S. (2020). Climate and poverty in Africa South of the Sahara. World Development, 125, 104691. https://doi.org/10.1016/j. worlddev.2019.104691

Baarsch, F., Granadillos, J. R., Hare, W., Knaus, M., Krapp, M., Schaeffer, M., \& Lotze-Campen, H. (2020). The impact of climate change on incomes and convergence in Africa. World Development, 126, 104699. https:// doi.org/10.1016/j.worlddev.2019.104699

Bakshi, B., Nawrotzki, R. J., Donato, J. R., \& Lelis, L. S. (2019). Exploring the link between climate variability and mortality in Sub-Saharan Africa. International Journal of Environment and Sustainable Development, 18(2), 206. https://doi.org/10.1504//JESD.2019.099518

Barbier, B., Yacouba, H., Karambiri, H., Zoromé, M., \& Somé, B. (2009). Human Vulnerability to Climate Variability in the Sahel: Farmers' Adaptation Strategies in Northern Burkina Faso. Environmental Management, 43(5), 790-803. https://doi.org/10.1007/s00267-0089237-9

Barrios, S., Ouattara, B., \& Strobl, E. (2008). The impact of climatic change 
on agricultural production: Is it different for Africa? Food Policy, 33(4), 287-298. https://doi.org/10.1016/j.foodpol.2008.01.003

Bayala, J., Sanou, J., Teklehaimanot, Z., Kalinganire, A., \& Ouédraogo, S. (2014). Parklands for buffering climate risk and sustaining agricultural production in the Sahel of West Africa. Current Opinion in Environmental Sustainability, 6, 28-34. https://doi.org/10.1016/j. cosust.2013.10.004

Bedeke, S. B., Vanhove, W., Wordofa, M. G., Natarajan, K., \& Van Damme, P. (2020). Vulnerability to climate change among maize-dependent smallholders in three districts of Ethiopia. Environment, Development and Sustainability, 22(2), 693-718. https://doi.org/10.1007/s10668018-0215-y

Belay, G. D., Ostadtaghizadeh, A., Khoei, E. M., Ardalan, A., HosseinzadehAttar, M. J., \& Assen, M. (2019). Estimating the household drought driven food insecurity using system dynamics model: The case of afar national regional state of Ethiopia. Human Antibodies, 1-17. https://doi.org/10.3233/HAB-190376

Belem, M., Manlay, R. J., Müller, J.-P., \& Chotte, J.-L. (2011). CaTMAS: A multi-agent model for simulating the dynamics of carbon resources of West African villages. Ecological Modelling , 222(20-22), 3651-3661. https://doi.org/10.1016/i.ecolmodel.2011.08.024

Belem, M., \& Saqalli, M. (2017). Development of an integrated generic model for multi-scale assessment of the impacts of agroecosystems on major ecosystem services in West Africa. Journal of Environmental Management,202, 117-125. https://doi.org/10.1016/j. jenvman.2017.07.018

Belesova, K., Gornott, C., Milner, J., Sié, A., Sauerborn, R., \& Wilkinson, P. (2019). Mortality impact of low annual crop yields in a subsistence farming population of Burkina Faso under the current and a $1.5{ }^{\circ} \mathrm{C}$ warmer climate in 2100. Science of the Total Environment, 691 , 538-548. https://doi.org/10.1016/j.scitotenv.2019.07.027

Belhabib, D., Lam, V. W. Y., \& Cheung, W. W. L. (2016). Overview of West African fisheries under climate change: Impacts, vulnerabilities and adaptive responses of the artisanal and industrial sectors. Marine Policy, 71, 15-28. https://doi.org/10.1016/j.marpol.2016.05.009

Bellassen, V., Manlay, R. J., Chéry, J.-P., Gitz, V., Touré, A., Bernoux, M., \& Chotte, J.-L. (2010). Multi-criteria spatialization of soil organic carbon sequestration potential from agricultural intensification in Senegal. Climatic Change, 98(1-2), 213-243. https://doi.org/10.1007/s10584009-9635-x

Benjaminsen, T. A., Alinon, K., Buhaug, H., \& Buseth, J. T. (2012). Does climate change drive land-use conflicts in the Sahel? Journal of Peace Research, 49(1), 97-111. https://doi.org/10.1177/0022343311427343

Bennetzen, E. H., Smith, P., \& Porter, J. R. (2016). Agricultural production and greenhouse gas emissions from world regions-The major trends over 40 years. Global Environmental Change, 37, 43-55. https://doi. org/10.1016/j.gloenvcha.2015.12.004

Berthou, S., Kendon, E. J., Rowell, D. P., Roberts, M. J., Tucker, S., \& Stratton, R. A. (2019). Larger Future Intensification of Rainfall in the West African Sahel in a Convection-Permitting Model. Geophysical Research Letters, 46(22), 13299-13307. https://doi. org/10.1029/2019GL083544

Bhaduri, A., Manna, U., Barbier, E., \& Liebe, J. (2011). Climate Change and Cooperation in Transboundary Water Sharing: An Application of Stochastic Stackelberg Differential Games in Volta River Basin. Natural Resource Modeling , 24(4), 409-444. https://doi.org/10.1111/ j.1939-7445.2011.00097.x

Biazin, B., Sterk, G., Temesgen, M., Abdulkedir, A., \& Stroosnijder, L. (2012). Rainwater harvesting and management in rainfed agricultural systems in sub-Saharan Africa - A review. Physics and Chemistry of the Earth, Parts $A / B / C, 47-48,139-151$. https://doi.org/10.1016/j. pce.2011.08.015

Bichet, A., \& Diedhiou, A. (2018). West African Sahel has become wetter during the last 30 years, but dry spells are shorter and more frequent. Climate Research, 75(2), 155-162. https://doi.org/10.3354/cr01515

Boansi, D., Tambo, J. A., \& Müller, M. (2017). Analysis of farmers' adaptation to weather extremes in West African Sudan Savanna. Weather and Climate Extremes, 16, 1-13. https://doi.org/10.1016/j. wace.2017.03.001

Boansi, D., Tambo, J. A., \& Müller, M. (2019). Intra-seasonal risk of agriculturally-relevant weather extremes in West African Sudan Savanna. Theoretical and Applied Climatology, 135(1-2), 355-373. https://doi.org/10.1007/s00704-018-2384-x

Bodin, P., Olin, S., Pugh, T. A. M., \& Arneth, A. (2016). Accounting for interannual variability in agricultural intensification: The potential of crop selection in Sub-Saharan Africa. Agricultural Systems, 148, 159-168. https://doi.org/10.1016/j.agsy.2016.07.012

Boillat, S., Jew, E. K. K., Steward, P. R., Speranza, C. I., Whitfield, S., Mkwambisi, D., Kiteme, B., Wambugu, G., Burdekin, O. J., \& Dougill, A. J. (2019). Can smallholder farmers buffer rainfall variability through conservation agriculture? On-farm practices and maize yields in Kenya and Malawi. Environmental Research Letters, 14(11), 115007. https://doi.org/10.1088/1748-9326/ab45ad

Bornemann, F. J., Rowell, D. P., Evans, B., Lapworth, D. J., Lwiza, K., Macdonald, D. M. J., Marsham, J. H., Tesfaye, K., Ascott, M. J., \& Way, C. (2019). Future changes and uncertainty in decision-relevant measures of East African climate. Climatic Change, 156(3), 365-384. https://doi.org/10.1007/s10584-019-02499-2

Borona, M., Mbow, C., \& Ouedraogo, I. (2016). Unstacking high temporal resolution meteorological data for multidimensional analysis of climate variability in southern Burkina Faso. Geografisk TidsskriftDanish Journal of Geography, 116(2), 176-189. https://doi.org/10.1 080/00167223.2016.1212668

Bostick, W. M., Bado, V. B., Bationo, A., Soler, C. T., Hoogenboom, G., \& Jones, J. W. (2007). Soil carbon dynamics and crop residue yields of cropping systems in the Northern Guinea Savanna of Burkina Faso. Soil and Tillage Research, 93(1), 138-151. https://doi.org/10.1016/j. still.2006.03.020

Botha, A., Kunert, K. J., Maling'a, J., \& Foyer, C. H. (2020). Defining biotechnological solutions for insect control in sub-Saharan Africa. Food and Energy Security, 9(1). https://doi.org/10.1002/fes3.191

Boubacar, I. (2015). Economic implications of climate change: evidence from agricultural productivity. International Journal of Global Warming, 7(3), 362. https://doi.org/10.1504/IJGW.2015.069367

Brandt, P., Herold, M., \& Rufino, M. C. (2018). The contribution of sectoral climate change mitigation options to national targets: a quantitative assessment of dairy production in Kenya. Environmental Research Letters, 13(3), 034016. https://doi.org/10.1088/1748-9326/aaac84

Brandt, P., Yesuf, G., Herold, M., \& Rufino, M. C. (2020). Intensification of dairy production can increase the GHG mitigation potential of the land use sector in East Africa. Global Change Biology , 26(2), 568-585. https://doi.org/10.1111/gcb.14870

Brockhaus, M., Djoudi, H., \& Kambire, H. (2012). Multi-level governance and adaptive capacity in west africa. International Journal of the Commons. https://doi.org/10.18352/ijc.331

Brottem, L., \& Brooks, B. (2018). Crops and livestock under the sun: Obstacles to rural livelihood adaptations to hotter 21st century temperatures in eastern Senegal. Land Degradation \& Development, 29(1), 118-126. https://doi.org/10.1002//dr.2844

Brown, C., Meeks, R., Hunu, K., \& Yu, W. (2011). Hydroclimate risk to economic growth in sub-Saharan Africa. Climatic Change, 106(4), 621-647. https://doi.org/10.1007/s10584-010-9956-9

Bryan, E., Bernier, O., Espinal, M., \& Ringler, C. (2018). Making climate change adaptation programmes in sub-Saharan Africa more gender responsive: insights from implementing organizations on the barriers and opportunities. Climate and Development, 10(5), 417-431. https:// doi.org/10.1080/17565529.2017.1301870

Bryan, E., Ringler, C., Okoba, B., Koo, J., Herrero, M., \& Silvestri, S. (2013). Can agriculture support climate change adaptation, greenhouse gas mitigation and rural livelihoods? Insights from Kenya. Climatic Change, 118(2), 151-165. https://doi.org/10.1007/s10584-012-0640-0

Buhaug, H., Benjaminsen, T. A., Sjaastad, E., \& Magnus Theisen, O. (2015). Climate variability, food production shocks, and violent conflict in Sub-Saharan Africa. Environmental Research Letters, 10(12), 125015. https://doi.org/10.1088/1748-9326/10/12/125015

Bunclark, L., Gowing, J., Oughton, E., Ouattara, K., Ouoba, S., \& Benao, D. (2018). Understanding farmers' decisions on adaptation to climate change: Exploring adoption of water harvesting technologies in Burkina Faso. Global Environmental Change, 48, 243-254. https:// doi.org/10.1016/j.gloenvcha.2017.12.004

Busby, J. W., Cook, K. H., Vizy, E. K., Smith, T. G., \& Bekalo, M. (2014). Identifying hot spots of security vulnerability associated with climate change in Africa. Climatic Change, 124(4), 717-731. https://doi. org/10.1007/s10584-014-1142-z

Cairns, J. E., Sonder, K., Zaidi, P. H., Verhulst, N., Mahuku, G., Babu, R., Nair, S. K., Das, B., Govaerts, B., Vinayan, M. T., Rashid, Z., Noor, J. J., Devi, P., San Vicente, F., \& Prasanna, B. M. (2012). Maize Production in a Changing Climate. In D. Sparks (Ed.), Advances in Agronomy 
(pp. 1-58). Elsevier B.V. https://doi.org/10.1016/B978-0-12-3942753.00006-7

Callo-Concha, D. (2018). Farmer Perceptions and Climate Change Adaptation in the West Africa Sudan Savannah: Reality Check in Dassari, Benin, and Dano, Burkina Faso. Climate, 6(2), 44. https:// doi.org/10.3390/cli6020044

Callo-Concha, D. (2016). West African Farmers' Climate Change Adaptation: From Technological Change Towards Transforming Institutions. In W. Filho, K. Adamson, R. Dunk, U. Azeiteiro, S. Illingworth, \& F. Alves (Eds.), World Symposium on Climate Change Adaptation (pp. 253-265). https://doi.org/10.1007/978-3-319-28591-7_14

Calzadilla, A., Zhu, T., Rehdanz, K., Tol, R. S. J., \& Ringler, C. (2013). Economywide impacts of climate change on agriculture in SubSaharan Africa. Ecological Economics, 93, 150-165. https://doi. org/10.1016/j.ecolecon.2013.05.006

Carr, E. R., Goble, R., Rosko, H. M., Vaughan, C., \& Hansen, J. (2020). Identifying climate information services users and their needs in Sub-Saharan Africa: a review and learning agenda. Climate and Development, 12(1), 23-41. https://doi.org/10.1080/17565529.201 9.1596061

Chah, J. M., Attamah, C. O., \& Odoh, E. M. (2018). Differences in climate change effects and adaptation strategies between male and female livestock entrepreneurs in Nsukka Agricultural Zone of Enugu State, Nigeria. Journal of Agricultural Extension, 22(1), 105. https://doi. org/10.4314/jae.v22i1.10

Chaney, N. W., Sheffield, J., Villarini, G., \& Wood, E. F. (2014). Development of a High-Resolution Gridded Daily Meteorological Dataset over Sub-Saharan Africa: Spatial Analysis of Trends in Climate Extremes. Journal of Climate, 27(15), 5815-5835. https://doi.org/10.1175/ JCLI-D-13-00423.1

Chen, M., Wichmann, B., Luckert, M., Winowiecki, L., Förch, W., \& Läderach, P. (2018). Diversification and intensification of agricultural adaptation from global to local scales. PLoS One, 13(5), e0196392. https://doi.org/10.1371/journal.pone.0196392

Choptiany, J. M. H., Phillips, S., Graeub, B. E., Colozza, D., Settle, W., Herren, B., \& Batello, C. (2017). SHARP: integrating a traditional survey with participatory self-evaluation and learning for climate change resilience assessment. Climate and Development, 9(6), 505-517. https://doi.org/10.1080/17565529.2016.1174661

Chuku, C. A., \& Okoye, C. (2009). Increasing resilience and reducing vulnerability in sub- Saharan African agriculture: Strategies for risk coping and management. African Journal of Agricultural Research, 4(13), 1524-1535.

Cobbing, J., \& Hiller, B. (2019). Waking a sleeping giant: Realizing the potential of groundwater in Sub-Saharan Africa. World Development, 122, 597-613. https://doi.org/10.1016/j.worlddev.2019.06.024

Conradie, B., Piesse, J., \& Stephens, J. (2019). The changing environment: Efficiency, vulnerability and changes in land use in the South African Karoo, 2012-2014. Environmental Development, 32, 100453. https:// doi.org/10.1016/j.envdev.2019.07.003

Cooper, P. J. M., Dimes, J., Rao, K. P. C., Shapiro, B., Shiferaw, B., \& Twomlow, S. (2008). Coping better with current climatic variability in the rain-fed farming systems of sub-Saharan Africa: An essential first step in adapting to future climate change? Agriculture, Ecosystems \& Environment, 126(1-2), 24-35. https://doi.org/10.1016/j. agee.2008.01.007

Corbeels, M., Cardinael, R., Naudin, K., Guibert, H., \& Torquebiau, E. (2019). The 4 per 1000 goal and soil carbon storage under agroforestry and conservation agriculture systems in sub-Saharan Africa. Soil and Tillage Research, 188, 16-26. https://doi.org/10.1016/j. still.2018.02.015

Corbeels, M., de Graaff, J., Ndah, T. H., Penot, E., Baudron, F., Naudin, K., Andrieu, N., Chirat, G., Schuler, J., Nyagumbo, I., Rusinamhodzi, L., Traore, K., Mzoba, H. D., \& Adolwa, I. S. (2014). Understanding the impact and adoption of conservation agriculture in Africa: A multiscale analysis. Agriculture, Ecosystems \& Environment, 187, 155-170. https://doi.org/10.1016/j.agee.2013.10.011

Coulibaly, Y. N., Mulia, R., Sanou, J., Zombré, G., Bayala, J., Kalinganire, A., \& van Noordwijk, M. (2014). Crop production under different rainfall and management conditions in agroforestry parkland systems in Burkina Faso: observations and simulation with WaNuLCAS model. Agroforestry Systems, 88(1), 13-28. https://doi.org/10.1007/s10457013-9651-8

D’haen, S. A. L., Nielsen, J. Ø., \& Lambin, E. F. (2014). Beyond local climate: rainfall variability as a determinant of household nonfarm activities in contemporary rural Burkina Faso. Climate and Development, 6(2), 144-165. https://doi.org/10.1080/17565529.2013.867246

Daccache, A., Sataya, W., \& Knox, J. W. (2015). Climate change impacts on rain-fed and irrigated rice yield in Malawi. International Journal of Agricultural Sustainability, 13(2), 87-103. https://doi.org/10.1080/ 14735903.2014.945317

Dale, A., Fant, C., Strzepek, K., Lickley, M., \& Solomon, S. (2017). Climate model uncertainty in impact assessments for agriculture: A multiensemble case study on maize in sub-Saharan Africa. Earth's Future, 5(3), 337-353. https://doi.org/10.1002/2017EF000539

Davenport, F., Funk, C., \& Galu, G. (2018). How will East African maize yields respond to climate change and can agricultural development mitigate this response? Climatic Change, 147(3-4), 491-506. https:// doi.org/10.1007/s10584-018-2149-7

de Vrese, P., Stacke, T., \& Hagemann, S. (2018). Exploring the biogeophysical limits of global food production under different climate change scenarios. Earth System Dynamics, 9(2), 393-412. https://doi. org/10.5194/esd-9-393-2018

Defrance, D., Ramstein, G., Charbit, S., Vrac, M., Famien, A. M., Sultan, B., Swingedouw, D., Dumas, C., Gemenne, F., Alvarez-Solas, J., \& Vanderlinden, J.-P. (2017). Consequences of rapid ice sheet melting on the Sahelian population vulnerability. Proceedings of the National Academy of Sciences, 114(25), 6533-6538. https://doi.org/10.1073/ pnas. 1619358114

Descheemaeker, K., Oosting, S. J., Homann-Kee Tui, S., Masikati, P., Falconnier, G. N., \& Giller, K. E. (2016). Climate change adaptation and mitigation in smallholder crop-livestock systems in subSaharan Africa: a call for integrated impact assessments. Regional Environmental Change, 16(8), 2331-2343. https://doi.org/10.1007/ s10113-016-0957-8

Di Leo, N., Escobedo, F. J., \& Dubbeling, M. (2016). The role of urban green infrastructure in mitigating land surface temperature in Bobo-Dioulasso, Burkina Faso. Environment, Development and Sustainability, 18(2), 373-392. https://doi.org/10.1007/s10668-0159653-y

Diao, X., Hazell, P., Resnick, D., \& Thurlow, J. (2007). The Role of Agriculture in Development: Implications for Sub-Saharan Africa. International Food Policy Research Institute. https://doi. org/10.2499/9780896291614RR153

Dimobe, K., Tondoh, J. E., Weber, J. C., Bayala, J., Ouédraogo, K., \& Greenough, K. (2018). Farmers' preferred tree species and their potential carbon stocks in southern Burkina Faso: Implications for biocarbon initiatives. PLoS One, 13(12), e0199488. https://doi. org/10.1371/journal.pone.0199488

Dixon, J., \& Stringer, L. (2015). Towards a Theoretical Grounding of Climate Resilience Assessments for Smallholder Farming Systems in SubSaharan Africa. Resources, 4(1), 128-154. https://doi.org/10.3390/ resources4010128

Djoudi, H., \& Brockhaus, M. (2011). Is adaptation to climate change gender neutral? Lessons from communities dependent on livestock and forests in northern Mali. International Forestry Review , 13(2), 123-135. https://doi.org/10.1505/146554811797406606

Doelman, J. C., Stehfest, E., Tabeau, A., van Meijl, H., Lassaletta, L. Gernaat, D. E. H. J., Hermans, K., Harmsen, M., Daioglou, V., Biemans, H., van der Sluis, S., \& van Vuuren, D. P. (2018). Exploring SSP land-use dynamics using the IMAGE model: Regional and gridded scenarios of land-use change and land-based climate change mitigation. Global Environmental Change, 48, 119-135. https://doi. org/10.1016/j.gloenvcha.2017.11.014

Döring, S. (2020). Come rain, or come wells: How access to groundwater affects communal violence. Political Geography, 76, 102073. https:// doi.org/10.1016/j.polgeo.2019.102073

Dougill, A. J., Whitfield, S., Stringer, L. C., Vincent, K., Wood, B. T., Chinseu, E. L., Steward, P., \& Mkwambisi, D. D. (2017). Mainstreaming conservation agriculture in Malawi: Knowledge gaps and institutional barriers. Journal of Environmental Management, 195, 25-34. https:// doi.org/10.1016/j.jenvman.2016.09.076

Douxchamps, S., Van Wijk, M. T., Silvestri, S., Moussa, A. S., Quiros, C. Ndour, N. Y. B., Buah, S., Somé, L., Herrero, M., Kristjanson, P., Ouedraogo, M., Thornton, P. K., Van Asten, P., Zougmoré, R., \& Rufino, M. C. (2016). Linking agricultural adaptation strategies, food security and vulnerability: evidence from West Africa. Regional Environmental Change, 16(5), 1305-1317. https://doi.org/10.1007/ 


\section{s10113-015-0838-6}

Druyan, L. M. (2011). Studies of 21st-century precipitation trends over West Africa. International Journal of Climatology, 31(10), 1415-1424. https://doi.org/10.1002/joc.2180

Dunning, C. M., Black, E. C. L., \& Allan, R. P. (2016). The onset and cessation of seasonal rainfall over Africa. Journal of Geophysical Research: Atmospheres, 121(19), 11,405-11,424. https://doi. org/10.1002/2016JD025428

ECOWAS-SWAC, OECD, \& CILSS. (2008). Climate and Climate Change. In The Atlas on Regional Integration in West Africa (pp. 1-24). ECOWASSWAC \& OECD.

Egbebiyi, Crespo, \& Lennard. (2019a). Defining Crop-climate Departure in West Africa: Improved Understanding of the Timing of Future Changes in Crop Suitability. Climate, 7(9), 101. https://doi. org/10.3390/cli7090101

Egbebiyi, T. S., Lennard, C., Crespo, O., Mukwenha, P., Lawal, S., \& Quagraine, K. (2019b). Assessing Future Spatio-Temporal Changes in Crop Suitability and Planting Season over West Africa: Using the Concept of Crop-Climate Departure. Climate, 7(9), 102. https://doi. org/10.3390/cli7090102

Egbendewe, A. Y. G. (2018). Climate Change Mitigation Potential in Agricultural and Forestry Sector: The Impact of Expanded Woody Biomass Co-firing on Global Climate Stabilization. In C. Kebe, A. Gueye, A. Ndiaye, \& A. Garba (Eds.), 2nd International Conference on Innovations and Interdisciplinary Solutions for Underserved Areas (InterSol) (pp. 133-142). https://doi.org/10.1007/978-3-319-988788 13

Egbendewe, A. Y. G., Lokonon, B. O. K., Atewemba, C., \& Coulibaly, N. (2017). Can intra-regional food trade increase food availability in the context of global climatic change in West Africa? Climatic Change, 145(1-2), 101-116. https://doi.org/10.1007/s10584-017-2083-0

El Bilali, H. (2019). Research on agro-food sustainability transitions: where are food security and nutrition? Food Security, 11(3), 559-577. https:// doi.org/10.1007/s12571-019-00922-1

El Bilali, H. (2020). Transition heuristic frameworks in research on agrofood sustainability transitions. Environment, Development and Sustainability, 22(3), 1693-1728. https://doi.org/10.1007/s10668018-0290-0

Elagib, N. A., Khalifa, M., Rahma, A. E., Babker, Z., \& Gamaledin, S. I. (2019). Performance of major mechanized rainfed agricultural production in Sudan: Sorghum vulnerability and resilience to climate since 1970. Agricultural and Forest Meteorology, 276-277, 107640. https://doi. org/10.1016/j.agrformet.2019.107640

Elum, Z. A., Modise, D. M., \& Nhamo, G. (2017). Climate change mitigation: the potential of agriculture as a renewable energy source in Nigeria. Environmental Science and Pollution Research, 24(4), 3260-3273. https://doi.org/10.1007/s11356-016-8187-7

England, M. I., Stringer, L. C., Dougill, A. J., \& Afionis, S. (2018). How do sectoral policies support climate compatible development? An empirical analysis focusing on southern Africa. Environmental Science \& Policy, 79, 9-15. https://doi.org/10.1016/j.envsci.2017.10.009

Epule, E. T., Peng, C., Lepage, L., \& Chen, Z. (2014). The causes, effects and challenges of Sahelian droughts: a critical review. Regional Environmental Change, 14(1), 145-156. https://doi.org/10.1007/ s10113-013-0473-z

Epule, T. E., Ford, J. D., \& Lwasa, S. (2017). Projections of maize yield vulnerability to droughts and adaptation options in Uganda. Land Use Policy, 65, 154-163. https://doi.org/10.1016/j.landusepol.2017.04.013

Fanzo, J., Davis, C., McLaren, R., \& Choufani, J. (2018). The effect of climate change across food systems: Implications for nutrition outcomes. Global Food Security, 18, 12-19. https://doi.org/10.1016/j. gfs.2018.06.001

FAO. (2016). The State of Food and Agriculture 2016 - Climate Change, Agriculture and Food Security. http://www.fao.org/3/a-i6030e.pdf

FAO, IFAD, UNICEF, WFP, \& WHO. (2018). The State of Food Security and Nutrition in the World 2018. Building climate resilience for food security and nutrition. http://www.fao.org/3//9553EN/i9553en.pdf

FAO, \& OECD. (2015). OECD-FAO Agricultural Outlook 2015. In OECD-FAO Agricultural Outlook. OECD. https://doi.org/10.1787/agr_outlook2015-en

Faramarzi, M., Abbaspour, K. C., Ashraf Vaghefi, S., Farzaneh, M. R., Zehnder, A. J. B., Srinivasan, R., \& Yang, H. (2013). Modeling impacts of climate change on freshwater availability in Africa. Journal of Hydrology, 480, 85-101. https://doi.org/10.1016/j.jhydrol.2012.12.016
Faye, B., Webber, H., Naab, J. B., MacCarthy, D. S., Adam, M., Ewert, F. Lamers, J. P. A., Schleussner, C.-F., Ruane, A., Gessner, U. Hoogenboom, G., Boote, K., Shelia, V., Saeed, F., Wisser, D., Hadir, S., Laux, P., \& Gaiser, T. (2018). Impacts of 1.5 versus $2.0^{\circ} \mathrm{C}$ on cereal yields in the West African Sudan Savanna. Environmental Research Letters, 13(3), 034014. https://doi.org/10.1088/1748-9326/aaab40

Ferner, J., Schmidtlein, S., Guuroh, R. T., Lopatin, J., \& Linstädter, A. (2018). Disentangling effects of climate and land-use change on West African drylands' forage supply. Global Environmental Change, 53, 24-38. https://doi.org/10.1016/j.gloenvcha.2018.08.007

Folberth, C., Yang, H., Gaiser, T., Liu, J., Wang, X., Williams, J., \& Schulin, R. (2014). Effects of ecological and conventional agricultura intensification practices on maize yields in sub-Saharan Africa under potential climate change. Environmental Research Letters, 9(4), 044004. https://doi.org/10.1088/1748-9326/9/4/044004

Fonta, W. M., Sanfo, S., Ibrahim, B., \& Barry, B. (2015). Farmers Awareness, Perception of Climate Hazards and their Willingness to Participate in Crop Insurance Schemes in Southwestern Burkina Faso. Procedia Environmenta/ Sciences, 29, 7-8. https://doi.org/10.1016/j. proenv.2015.07.127

Forabosco, F., Chitchyan, Z., \& Mantovani, R. (2017). Methane, nitrous oxide emissions and mitigation strategies for livestock in developing countries: A review. South African Journal of Animal Science, 47(3), 268. https://doi.org/10.4314/sajas.v47i3.3

Freduah, B., MacCarthy, D., Adam, M., Ly, M., Ruane, A., Timpong-Jones, E., Traore, P., Boote, K., Porter, C., \& Adiku, S. (2019). Sensitivity of Maize Yield in Smallholder Systems to Climate Scenarios in Semi-Arid Regions of West Africa: Accounting for Variability in Farm Management Practices. Agronomy, 9(10), 639. https://doi. org/10.3390/agronomy9100639

Freduah, G., Fidelman, P., \& Smith, T. F. (2019). Adaptive capacity of small[ scale coastal fishers to climate and non $\square$ climate stressors in the Western region of Ghana. The Geographical Journal, 185(1), 96-110. https://doi.org/10.1111/geoj.12282

Gahi, N., Dongo, K., \& Badolo, M. (2015). Using a New Approach to Design Innovative Tools for Monitoring and Evaluating Water Policy of Burkina Faso in Response to Climate Risks. Climate, 3(4), 1057-1078. https:// doi.org/10.3390/cli3041057

Gaisberger, H., Kindt, R., Loo, J., Schmidt, M., Bognounou, F., Da, S. S., Diallo, O. B., Ganaba, S., Gnoumou, A., Lompo, D., Lykke, A. M. Mbayngone, E., Nacoulma, B. M. I., Ouedraogo, M., Ouédraogo, O. Parkouda, C., Porembski, S., Savadogo, P. Thiombiano, A., Vinceti, B. (2017). Spatially explicit multi-threat assessment of food tree species in Burkina Faso: A fine-scale approach. PLoS One, 12(9), e0184457. https://doi.org/10.1371/journal.pone.0184457

García de Jalón, S., Iglesias, A., \& Barnes, A. P. (2016). Drivers of farm-level adaptation to climate change in Africa: an evaluation by a composite index of potential adoption. Mitigation and Adaptation Strategies for Global Change, 21(5), 779-798. https://doi.org/10.1007/s11027014-9626-8

García de Jalón, S., Iglesias, A., \& Neumann, M. B. (2018). Responses of sub-Saharan smallholders to climate change: Strategies and drivers of adaptation. Environmenta/ Science \& Policy, 90, 38-45. https://doi. org/10.1016/j.envsci.2018.09.013

García de Jalón, S., Silvestri, S., \& Barnes, A. P. (2017). The potential for adoption of climate smart agricultural practices in Sub-Saharan livestock systems. Regional Environmental Change, 17(2), 399-410. https://doi.org/10.1007/s10113-016-1026-z

Garnot, S. F. V., Groth, A., \& Ghil, M. (2018). Coupled Climate-Economic Modes in the Sahel's Interannual Variability. Ecological Economics, 153, 111-123. https://doi.org/10.1016/j.ecolecon.2018.07.006

Garrity, D. P., Akinnifesi, F. K., Ajayi, O. C., Weldesemayat, S. G., Mowo, J. G., Kalinganire, A., Larwanou, M., \& Bayala, J. (2010). Evergreen Agriculture: a robust approach to sustainable food security in Africa. Food Security, 2(3), 197-214. https://doi.org/10.1007/s12571-0100070-7

Gautier, D., Denis, D., \& Locatelli, B. (2016). Impacts of drought and responses of rural populations in West Africa: a systematic review. Wiley Interdisciplinary Reviews: Climate Change, 7(5), 666-681. https://doi.org/10.1002/wcc.411

Gbegbelegbe, S., Serem, J., Stirling, C., Kyazze, F., Radeny, M., Misiko, M., Tongruksawattana, S., Nafula, L., Gakii, M., \& Sonder, K. (2018). Smallholder farmers in eastern Africa and climate change: a review of risks and adaptation options with implications for future adaptation 
programmes. Climate and Development, 10(4), 289-306. https://doi. org/10.1080/17565529.2017.1374236

Gebremeskel Haile, G., Tang, Q., Sun, S., Huang, Z., Zhang, X., \& Liu, X. (2019). Droughts in East Africa: Causes, impacts and resilience. Earth-Science Reviews, 193, 146-161. https://doi.org/10.1016/j. earscirev.2019.04.015

Gerssen-Gondelach, S. J., Lauwerijssen, R. B. G., Havlík, P., Herrero, M., Valin, H., Faaij, A. P. C., \& Wicke, B. (2017). Intensification pathways for beef and dairy cattle production systems: Impacts on GHG emissions, land occupation and land use change. Agriculture, Ecosystems \& Environment, 240, 135-147. https://doi.org/10.1016/j. agee.2017.02.012

Giannini, A., Krishnamurthy, P. K., Cousin, R., Labidi, N., \& Choularton, R. J. (2017). Climate risk and food security in Mali: A historical perspective on adaptation. Earth's Future, 5(2), 144-157. https://doi. org/10.1002/2016EF000404

Gil, J. D. B., Cohn, A. S., Duncan, J., Newton, P., \& Vermeulen, S. (2017). The resilience of integrated agricultural systems to climate change. Wiley Interdisciplinary Reviews: Climate Change, 8(4), e461. https:// doi.org/10.1002/wcc.461

Godber, O. F., \& Wall, R. (2014). Livestock and food security: vulnerability to population growth and climate change. Global Change Biology, 20(10), 3092-3102. https://doi.org/10.1111/gcb.12589

Gray, C., \& Wise, E. (2016). Country-specific effects of climate variability on human migration. Climatic Change, 135(3-4), 555-568. https:// doi.org/10.1007/s10584-015-1592-y

Groten, S. M. E., \& Ocatre, R. (2002). Monitoring the length of the growing season with NOAA. International Journal of Remote Sensing ,23(14), 2797-2815. https://doi.org/10.1080/01431160110070843

Guan, K., Sultan, B., Biasutti, M., Baron, C., \& Lobell, D. B. (2015). What aspects of future rainfall changes matter for crop yields in West Africa? Geophysical Research Letters, 42(19), 8001-8010. https:// doi.org/10.1002/2015GL063877

Guan, K., Sultan, B., Biasutti, M., Baron, C., \& Lobell, D. B. (2017). Assessing climate adaptation options and uncertainties for cereal systems in West Africa. Agricultural and Forest Meteorology, 232, 291-305. https://doi.org/10.1016/j.agrformet.2016.07.021

Hadebe, S. T., Modi, A. T., \& Mabhaudhi, T. (2017). Drought Tolerance and Water Use of Cereal Crops: A Focus on Sorghum as a Food Security Crop in Sub-Saharan Africa. Journal of Agronomy and Crop Science, 203(3), 177-191. https://doi.org/10.1111/jac. 12191

Haile, B., Signorelli, S., Azzarri, C., \& Johnson, T. (2018). Welfare effects of weather variability: Multi-country evidence from Africa south of the Sahara. PLoS One, 13(11), e0206415. https://doi.org/10.1371/ journal.pone.0206415

Haile, M. (2005). Weather patterns, food security and humanitarian response in sub-Saharan Africa. Philosophical Transactions of the Royal Society B: Biological Sciences, 360(1463), 2169-2182. https:// doi.org/10.1098/rstb.2005.1746

Hänke, H., Börjeson, L., Hylander, K., \& Enfors-Kautsky, E. (2016). Drought tolerant species dominate as rainfall and tree cover returns in the West African Sahel. Land Use Policy, 59, 111-120. https://doi. org/10.1016/j.landusepol.2016.08.023

Hansen, J. W., Mason, S. J., Sun, L., \& Tall, A. (2011). Review of Seasonal Climate Forecasting for Agriculture in Sub-Saharan Africa. Experimental Agriculture, 47(2), 205-240. https://doi.org/10.1017/ S0014479710000876

Hasegawa, T., Fujimori, S., Havlík, P., Valin, H., Bodirsky, B. L., Doelman, J. C. Fellmann, T., Kyle, P., Koopman, J. F. L., Lotze-Campen, H., MasonD’Croz, D., Ochi, Y., Pérez Domínguez, I., Stehfest, E., Sulser, T. B., Tabeau, A., Takahashi, K., Takakura, J., van Meijl, H.,... Witzke, P. (2018). Risk of increased food insecurity under stringent global climate change mitigation policy. Nature Climate Change, 8(8), 699-703. https://doi.org/10.1038/s41558-018-0230-x

Hassan, R. M. (2010). The double challenge of adapting to climate change while accelerating development in sub-Saharan Africa. Environment and Development Economics, 15(6), 661-685. https:// doi.org/10.1017/S1355770X10000306

Hassen, A., Talore, D. G., Tesfamariam, E. H., Friend, M. A., \& Mpanza, T. D. E. (2017). Potential use of forage-legume intercropping technologies to adapt to climate-change impacts on mixed crop-livestock systems in Africa: a review. Regional Environmental Change, 17(6), 1713-1724. https://doi.org/10.1007/s10113-017-1131-7

Haussmann, B. I. G., Fred Rattunde, H., Weltzien-Rattunde, E.,
Traoré, P. S. C., vom Brocke, K., \& Parzies, H. K. (2012). Breeding Strategies for Adaptation of Pearl Millet and Sorghum to Climate Variability and Change in West Africa. Journal of Agronomy and Crop Science, 198(5), 327-339. https://doi.org/10.1111/j.1439037X.2012.00526.X

Henderson, B., Falcucci, A., Mottet, A., Early, L., Werner, B., Steinfeld, H. \& Gerber, P. (2017). Marginal costs of abating greenhouse gases in the global ruminant livestock sector. Mitigation and Adaptation Strategies for Global Change, 22(1), 199-224. https://doi.org/10.1007/ s11027-015-9673-9

Henderson, B., Godde, C., Medina-Hidalgo, D., van Wijk, M., Silvestri, S., Douxchamps, S., Stephenson, E., Power, B., Rigolot, C., Cacho, O. \& Herrero, M. (2016). Closing system-wide yield gaps to increase food production and mitigate GHGs among mixed crop-livestock smallholders in Sub-Saharan Africa. Agricultural Systems, 143, 106-113. https://doi.org/10.1016/j.agsy.2015.12.006

Henderson, Benjamin, Cacho, O., Thornton, P., van Wijk, M., \& Herrero, M. (2018). The economic potential of residue management and fertilizer use to address climate change impacts on mixed smallholder farmers in Burkina Faso. Agricultural Systems, 167, 195-205. https://doi. org/10.1016/j.agsy.2018.09.012

Hendrix, C. S., \& Glaser, S. M. (2007). Trends and triggers: Climate, climate change and civil conflict in Sub-Saharan Africa. Political Geography 26(6), 695-715. https://doi.org/10.1016/j.polgeo.2007.06.006

Hertel, T. W., \& Lobell, D. B. (2014). Agricultural adaptation to climate change in rich and poor countries: Current modeling practice and potential for empirical contributions. Energy Economics, 46, 562-575. https:// doi.org/10.1016/j.eneco.2014.04.014

Heubes, J., Schmidt, M., Stuch, B., García Márquez, J. R., Wittig, R. Zizka, G., Thiombiano, A., Sinsin, B., Schaldach, R., \& Hahn, K. (2013). The projected impact of climate and land use change on plant diversity: An example from West Africa. Journal of Arid Environments, 96, 48-54. https://doi.org/10.1016/j.jaridenv.2013.04.008

HLPE. (2012). Food security and climate change. A report by the High Level Panel of Experts on food security and nutrition of the Committee on World Food Security. http://www.fao.org/fileadmin/user upload/hlpe/ hlpe documents/HLPE Reports/HLPE-Report-3-Food security and climate change-June 2012 .pdf

Hoffman, A. L., Kemanian, A. R., \& Forest, C. E. (2018). Analysis of climate signals in the crop yield record of sub-Saharan Africa. Global Change Biology, 24(1), 143-157. https://doi.org/10.1111/gcb.13901

Houessou, S. O., Dossa, L. H., Diogo, R. V. C., Houinato, M., Buerkert, A., \& Schlecht, E. (2019). Change and continuity in traditional cattle farming systems of West African Coast countries: A case study from Benin. Agricultura/ Systems, 168, 112-122. https://doi.org/10.1016/j. agsy.2018.11.003

Huyer, S. (2016). Closing the Gender Gap in Agriculture. Gender, Technology and Development, 20(2), 105-116. https://doi. org/10.1177/0971852416643872

Ingram, K.., Roncoli, M.., \& Kirshen, P.. (2002). Opportunities and constraints for farmers of west Africa to use seasonal precipitation forecasts with Burkina Faso as a case study. Agricultural Systems, 74(3), 331-349. https://doi.org/10.1016/S0308-521X(02)00044-6

Institut National de la Statistique et de la Démographie, \& ORC Macro. (2004). Enquête Démographique et de Santé du Burkina Faso 2003. https://dhsprogram.com/pubs/pdf/FR154/FR154.pdf

Intergovernmental Panel on Climate Change. (2012). Sustainable Development and mitigation. In Climate Change 2007 (pp. 691-744). Cambridge University Press. https://doi.org/10.1017/ CBO9780511546013.016

International Crisis Group. (2020). The Central Sahel: Scene of New Climate Wars? Crisis Group Africa Briefing No154, 8. https://d2071andvip0wj. cloudfront.net/b154-sahel-new-climate-wars.pdf

IPCC. (2007). Contribution of Working Group II to the Fourth Assessment Report of the Intergovernmental Panel on Climate Change. In M. L. Parry, O. F. Canziani, J. P. Palutikof, P. J. van der Linden, \& C. E. Hanson (Eds.), Climate Change 2007: Impacts, Adaptation and Vulnerability. Cambridge University Press.

Islam, S., Cenacchi, N., Sulser, T. B., Gbegbelegbe, S., Hareau, G. Kleinwechter, U., Mason-D'Croz, D., Nedumaran, S., Robertson, R., Robinson, S., \& Wiebe, K. (2016). Structural approaches to modeling the impact of climate change and adaptation technologies on crop yields and food security. Global Food Security, 10, 63-70. https://doi. org/10.1016/j.gfs.2016.08.003 
Issahaku, A.-R., Campion, B. B., \& Edziyie, R. (2016). Rainfall and temperature changes and variability in the Upper East Region of Ghana. Earth and Space Science, 3(8), 284-294. https://doi. org/10.1002/2016EA000161

Jahel, C., Baron, C., Vall, E., Karambiri, M., Castets, M., Coulibaly, K., Bégué, A., \& Lo Seen, D. (2017). Spatial modelling of agro-ecosystem dynamics across scales: A case in the cotton region of West-Burkina Faso. Agricultura/ Systems, 157, 303-315. https://doi.org/10.1016/j. agsy.2016.05.016

Jarvis, A., Ramirez-Villegas, J., Herrera Campo, B. V., \& Navarro-Racines, C. (2012). Is Cassava the Answer to African Climate Change Adaptation? Tropical Plant Biology, 5(1), 9-29. https://doi.org/10.1007/s12042012-9096-7

Johnson, K., \& Brown, M. E. (2014). Environmental risk factors and child nutritional status and survival in a context of climate variability and change. Applied Geography, 54, 209-221. https://doi.org/10.1016/j. apgeog.2014.08.007

Jones, P. G., \& Thornton, P. K. (2009). Croppers to livestock keepers: livelihood transitions to 2050 in Africa due to climate change. Environmental Science \& Policy, 12(4), 427-437. https://doi. org/10.1016/j.envsci.2008.08.006

Jost, C., Kyazze, F., Naab, J., Neelormi, S., Kinyangi, J., Zougmore, R., Aggarwal, P., Bhatta, G., Chaudhury, M., Tapio-Bistrom, M. L., Nelson, S., \& Kristjanson, P. (2016). Understanding gender dimensions of agriculture and climate change in smallholder farming communities. Climate and Development, 8(2), 133-144. https://doi. org/10.1080/17565529.2015.1050978

Jun, T. (2017). Temperature, maize yield, and civil conflicts in sub-Saharan Africa. Climatic Change, 142(1-2), 183-197. https://doi.org/10.1007/ s10584-017-1941-0

Jung, G., Wagner, S., \& Kunstmann, H. (2012). Joint climate-hydrology modeling: an impact study for the data-sparse environment of the Volta Basin in West Africa. Hydrology Research, 43(3), 231-248. https://doi.org/10.2166/nh.2012.044

Kahsay, G. A., \& Hansen, L. G. (2016). The effect of climate change and adaptation policy on agricultural production in Eastern Africa. Ecological Economics, 121, 54-64. https://doi.org/10.1016/j. ecolecon.2015.11.016

Kalame, F. B., Kudejira, D., \& Nkem, J. (2011). Assessing the process and options for implementing National Adaptation Programmes of Action (NAPA): a case study from Burkina Faso. Mitigation and Adaptation Strategies for Global Change, 16(5), 535-553. https://doi.org/10.1007/ s11027-010-9278-2

Kamali, B., Abbaspour, K. C., Wehrli, B., \& Yang, H. (2018). Drought vulnerability assessment of maize in Sub-Saharan Africa: Insights from physical and social perspectives. Global and Planetary Change, 162, 266-274. https://doi.org/10.1016/j.gloplacha.2018.01.011

Kamali, B., Abbaspour, K. C., Wehrli, B., \& Yang, H. (2019). A Quantitative Analysis of Socio-Economic Determinants Influencing Crop Drought Vulnerability in Sub-Saharan Africa. Sustainability, 11(21), 6135. https://doi.org/10.3390/su11216135

Kamoni, P. T., \& Gicheru, P. T. (2015). Managing Soil Organic Carbon for Multiple Benefits: The Case of Africa. In S. Banwart, E. Noellemeyer, \& E. Milne (Eds.), Soil Carbon: Science, Management And Policy For Multiple Benefits (pp. 307-313). CABI Publishing.

Katikiro, R. E., \& Macusi, E. D. (2012). Impacts of climate change on West African fisheries and its implications on food production. Journal of Environmental Science and Management, 15(2), 83-95.

Kim, D.-G., Thomas, A. D., Pelster, D., Rosenstock, T. S., \& Sanz-Cobena, A. (2016). Greenhouse gas emissions from natural ecosystems and agricultural lands in sub-Saharan Africa: synthesis of available data and suggestions for further research. Biogeosciences, 13(16), 4789-4809. https://doi.org/10.5194/bg-13-4789-2016

Kima, A. S., Traore, S., Wang, Y.-M., \& Chung, W.-G. (2014). Multi-genes programing and local scale regression for analyzing rice yield response to climate factors using observed and downscaled data in Sahel. Agricultural Water Management, 146, 149-162. https://doi. org/10.1016/j.agwat.2014.08.007

Kima, S. A., Okhimamhe, A. A., Kiema, A., Zampaligre, N., \& Sule, I. (2015). Adapting to the impacts of climate change in the sub-humid zone of Burkina Faso, West Africa: Perceptions of agro-pastoralists. Pastoralism, 5(1), 16. https://doi.org/10.1186/s13570-015-0034-9

Kimani, S. K., Esilaba, A. O., Njeru, P. N. M., Miriti, J. M., Lekasi, J. K., \& Koala, S. (2015). Improving Livelihoods in Semi-arid Regions of
Africa through Reduced Vulnerability to Climate Variability and Promotion of Climate Resilience. In W. Leal Filho, A. Esilaba, K. Rao, \& G. Sridhar (Eds.), Adapting African Agriculture to Climate Change. Climate Change Management (pp. 25-33). Springer. https://doi. org/10.1007/978-3-319-13000-2 2

Klutse, N. A. B., Ajayi, V. O., Gbobaniyi, E. O., Egbebiyi, T. S., Kouadio, K. Nkrumah, F., Quagraine, K. A., Olusegun, C., Diasso, U., Abiodun, B. J., Lawal, K. Nikulin, G., Lennard, C. \& Dosio, A. (2018). Potential impact of $1.5^{\circ} \mathrm{C}$ and $2{ }^{\circ} \mathrm{C}$ global warming on consecutive dry and wet days over West Africa. Environmental Research Letters, 13(5), 055013. https://doi.org/10.1088/1748-9326/aab37b

Kniveton, D. R., Smith, C. D., \& Black, R. (2012). Emerging migration flows in a changing climate in dryland Africa. Nature Climate Change, 2(6), 444-447. https://doi.org/10.1038/nclimate1447

Komarek, A. M., Kwon, H., Haile, B., Thierfelder, C., Mutenje, M. J., \& Azzarri, C. (2019). From plot to scale: ex-ante assessment of conservation agriculture in Zambia. Agricultural Systems, 173, 504-518. https://doi.org/10.1016/j.agsy.2019.04.001

Koo, H., Kleemann, J., \& Fürst, C. (2019). Impact assessment of land use changes using local knowledge for the provision of ecosystem services in northern Ghana, West Africa. Ecological Indicators, 103 156-172. https://doi.org/10.1016/j.ecolind.2019.04.002

Koubi, V. (2019). Climate Change and Conflict. Annual Review of Political Science, 22(1), 343-360. https://doi.org/10.1146/annurevpolisci-050317-070830

Lahive, F., Hadley, P., \& Daymond, A. J. (2019). The physiological responses of cacao to the environment and the implications for climate change resilience. A review. Agronomy for Sustainable Development, 39(1), 5. https://doi.org/10.1007/s13593-018-0552-0

Lahmar, R., Bationo, B. A., Dan Lamso, N., Guéro, Y., \& Tittonell, P. (2012). Tailoring conservation agriculture technologies to West Africa semiarid zones: Building on traditional local practices for soil restoration. Field Crops Research, 132, 158-167. https://doi.org/10.1016/j. fcr.2011.09.013

Lal, R. (2019). Promoting "4 Per Thousand" and "Adapting African Agriculture" by south-south cooperation: Conservation agriculture and sustainable intensification. Soil and Tillage Research, 188, 27-34. https://doi.org/10.1016/..still.2017.12.015

Lalou, R., Sultan, B., Muller, B., \& Ndonky, A. (2019). Does climate opportunity facilitate smallholder farmers' adaptive capacity in the Sahel? Palgrave Communications, 5(1), 81. https://doi.org/10.1057/ s41599-019-0288-8

Lam, V., Cheung, W., Swartz, W., \& Sumaila, U. (2012). Climate change impacts on fisheries in West Africa: implications for economic, food and nutritional security. African Journal of Marine Science, 34(1), 103-117. https://doi.org/10.2989/1814232X.2012.673294

Lambin, E. F., D'haen, S. A. L., Mertz, O., Nielsen, J. Ø., \& Rasmussen, K. (2014). Scenarios on future land changes in the West African Sahel. Geografisk Tidsskrift-Danish Journal of Geography, 114(1), 76-83. https://doi.org/10.1080/00167223.2013.878229

Lauria, V., Das, I., Hazra, S., Cazcarro, I., Arto, I., Kay, S., Ofori-Danson, P., Ahmed, M., Hossain, M. A. R., Barange, M., \& Fernandes, J. A. (2018). Importance of fisheries for food security across three climate change vulnerable deltas. Science of the Total Environment, 640-641, 1566-1577. https://doi.org/10.1016/j.scitotenv.2018.06.011

Lay, J., Narloch, U., \& Mahmoud, T. O. (2009). Shocks, Structural Change, and the Patterns of Income Diversification in Burkina Faso. African Development Review, 21(1), 36-58. https://doi.org/10.1111/j.14678268.2009.00202.x

Le Houérou, H. N. (1996). Climate change, drought and desertification. Journal of Arid Environments, 34(2), 133-185. https://doi.org/10.1006/ jare.1996.0099

Lebel, S., Fleskens, L., Forster, P. M., Jackson, L. S., \& Lorenz, S. (2015). Evaluation of In Situ Rainwater Harvesting as an Adaptation Strategy to Climate Change for Maize Production in Rainfed Africa. Water Resources Management, 29(13), 4803-4816. https://doi.org/10.1007/ s11269-015-1091-y

Limuwa, M., Sitaula, B., Njaya, F., \& Storebakken, T. (2018). Evaluation of Small-Scale Fishers' Perceptions on Climate Change and Their Coping Strategies: Insights from Lake Malawi. Climate, 6(2), 34. https://doi. org/10.3390/cli6020034

Liu, J., Folberth, C., Yang, H., Röckström, J., Abbaspour, K., \& Zehnder A. J. B. (2013). A Global and Spatially Explicit Assessment of Climate Change Impacts on Crop Production and Consumptive 
Water Use. PLoS One, 8(2), e57750. https://doi.org/10.1371/journal. pone. 0057750

Liverpool-Tasie, L. S. O., Sanou, A., \& Tambo, J. A. (2019). Climate change adaptation among poultry farmers: evidence from Nigeria. Climatic Change, 157(3-4), 527-544. https://doi.org/10.1007/s10584-01902574-8

Lobell, D. B., Burke, M. B., Tebaldi, C., Mastrandrea, M. D., Falcon, W. P., \& Naylor, R. L. (2008). Prioritizing Climate Change Adaptation Needs for Food Security in 2030. Science, 319(5863), 607-610. https://doi. org/10.1126/science.1152339

Lobell, David B, Baldos, U. L. C., \& Hertel, T. W. (2013). Climate adaptation as mitigation: the case of agricultural investments. Environmental Research Letters, 8(1), 015012. https://doi.org/10.1088/17489326/8/1/015012

Loboguerrero, A. M., Campbell, B., Cooper, P., Hansen, J., Rosenstock, T., \& Wollenberg, E. (2019). Food and Earth Systems: Priorities for Climate Change Adaptation and Mitigation for Agriculture and Food Systems. Sustainability, 11(5), 1372. https://doi.org/10.3390/su11051372

Lodoun, T., Sanon, M., Giannini, A., Traoré, P. S., Somé, L., \& Rasolodimby, J. M. (2014). Seasonal forecasts in the Sahel region: the use of rainfall-based predictive variables. Theoretical and Applied Climatology, 117(3-4), 485-494. https://doi.org/10.1007/s00704013-1002-1

Lokonon, B. O. K., Egbendewe, A. Y. G., Coulibaly, N., \& Atewamba, C. (2019). The Potential Impact of Climate Change on Agriculture in West Africa: A Bio-Economic Modeling Approach. Climate Change Economics, 10(04), 1950015. https://doi.org/10.1142/ S2010007819500155

López-Carr, D., Pricope, N. G., Aukema, J. E., Jankowska, M. M., Funk, C., Husak, G., \& Michaelsen, J. (2014). A spatial analysis of population dynamics and climate change in Africa: potential vulnerability hot spots emerge where precipitation declines and demographic pressures coincide. Population and Environment, 35(3), 323-339. https://doi.org/10.1007/s11111-014-0209-0

Luedeling, E., \& Neufeldt, H. (2012). Carbon sequestration potential of parkland agroforestry in the Sahel. Climatic Change, 115(3-4), 443-461. https://doi.org/10.1007/s10584-012-0438-0

Luetkemeier, R., Stein, L., Drees, L., Müller, H., \& Liehr, S. (2018). Uncertainty of Rainfall Products: Impact on Modelling Household Nutrition from Rain-Fed Agriculture in Southern Africa. Water, 10(4), 499. https://doi.org/10.3390/w10040499

Luginaah, I., Weis, T., Galaa, S., Nkrumah, M. K., Benzer-Kerr, R., \& Bagah, D. (2009). Environment, Migration and Food Security in the Upper West Region of Ghana. In Environment and Health in Sub-Saharan Africa: Managing an Emerging Crisis (pp. 25-38). Springer Netherlands. https://doi.org/10.1007/978-1-4020-9382-1_2

Mahe, G., Lienou, G., Descroix, L., Bamba, F., Paturel, J. E., Laraque, A., Meddi, M., Habaieb, H., Adeaga, O., Dieulin, C., Chahnez Kotti, F., \& Khomsi, K. (2013). The rivers of Africa: witness of climate change and human impact on the environment. Hydrological Processes, 27(15), 2105-2114. https://doi.org/10.1002/hyp.9813

Mainardi, S. (2011). Cropland use, yields, and droughts: Spatial data modeling for Burkina Faso and Niger. Agricultural Economics, 42(1), 17-33. https://doi.org/10.1111/j.1574-0862.2010.00465.x

Makate, C. (2019). Local institutions and indigenous knowledge in adoption and scaling of climate-smart agricultural innovations among subSaharan smallholder farmers. International Journal of Climate Change Strategies and Management, 12(2), 270-287. https://doi.org/10.1108/ IJCCSM-07-2018-0055

Makate, C., Makate, M., Mango, N., \& Siziba, S. (2019). Increasing resilience of smallholder farmers to climate change through multiple adoption of proven climate-smart agriculture innovations. Lessons from Southern Africa. Journal of Environmental Management, 231. 858-868. https://doi.org/10.1016/j.jenvman.2018.10.069

Mande, T., Ceperley, N. C., Katul, G. G., Tyler, S. W., Yacouba, H., \& Parlange, M. B. (2015). Suppressed convective rainfall by agricultural expansion in southeastern $<\mathrm{scp}>\mathrm{B}</ \mathrm{scp}>$ urkina $<\mathrm{scp}>\mathrm{F}</ \mathrm{scp}>$ aso. Water Resources Research, 51(7), 5521-5530. https://doi. org/10.1002/2015WR017144

Marchant, R., Richer, S., Boles, O., Capitani, C., Courtney-Mustaphi, C. J., Lane, P., Prendergast, M. E., Stump, D., De Cort, G., Kaplan, J. O., Phelps, L., Kay, A., Olago, D., Petek, N., Platts, P. J., Punwong, P., Widgren, M., Wynne-Jones, S., Ferro-Vázquez, C.,... Wright, D. (2018). Drivers and trajectories of land cover change in East Africa: Human and environmental interactions from 6000 years ago to present. Earth-Science Reviews, 178, 322-378. https://doi.org/10.1016/j. earscirev.2017.12.010

Mare, F., Bahta, Y. T., \& Van Niekerk, W. (2018). The impact of drought on commercial livestock farmers in South Africa. Development in Practice, 28(7), 884-898. https://doi.org/10.1080/09614524.2018. 1493091

Mbow, C., Fensholt, R., Nielsen, T. T., \& Rasmussen, K. (2014). Advances in monitoring vegetation and land use dynamics in the Sahel. Geografisk Tidsskrift-Danish Journal of Geography, 114(1), 84-91. https://doi.or g/10.1080/00167223.2014.886515

McPeak, J. (2017). The Role of Pastoralists' Tradition/Cultural Institutions in Climate Change Resilience in West Africa. In Z. Tang \& S. Zhao (Eds.), 12th International Conference on Public Administration \& 1st International Symposium on West African Studies (pp. 805-818). University of Ghana.

Mertz, O., Mbow, C., Nielsen, J. Ø., Maiga, A., Diallo, D., Reenberg, A., Diouf, A., Barbier, B., Moussa, I. B., Zorom, M., Ouattara, I., \& Dabi, D. (2010). Climate factors play a limited role for past adaptation strategies in West Africa. Ecology and Society. https:// doi.org/10.5751/ES-03774-150425

Mertz, O., Mbow, C., Reenberg, A., Genesio, L., Lambin, E. F., D’haen, S., Zorom, M., Rasmussen, K., Diallo, D., Barbier, B., Moussa, I. B., Diouf, A., Nielsen, J. Ø., \& Sandholt, I. (2011). Adaptation strategies and climate vulnerability in the Sudano-Sahelian region of West Africa. Atmospheric Science Letters, 12(1), 104-108. https://doi. org/10.1002/asl.314

Mertz, O., Rasmussen, K., \& Rasmussen, L. V. (2016). Weather and resource information as tools for dealing with farmer\&amp;ndash; pastoralist conflicts in the Sahel. Earth System Dynamics, 7(4), 969-976. https:// doi.org/10.5194/esd-7-969-2016

Minasny, B., Malone, B. P., McBratney, A. B., Angers, D. A., Arrouays, D., Chambers, A., Chaplot, V., Chen, Z.-S., Cheng, K., Das, B. S., Field, D. J., Gimona, A., Hedley, C. B., Hong, S. Y., Mandal, B., Marchant, B. P., Martin, M., McConkey, B. G., Mulder, V. L.,... Winowiecki, L. (2017). Soil carbon 4 per mille. Geoderma, 292, 59-86. https://doi.org/10.1016/j.geoderma.2017.01.002

Mishra, A., Hansen, J. W., Dingkuhn, M., Baron, C., Traoré, S. B., Ndiaye, O. $\&$ Ward, M. N. (2008). Sorghum yield prediction from seasonal rainfall forecasts in Burkina Faso. Agricultural and Forest Meteorology, 148(11), 1798-1814. https://doi.org/10.1016/j.agrformet.2008.06.007

Mngumi, L. E. (2020). Ecosystem services potential for climate change resilience in peri-urban areas in Sub-Saharan Africa. Landscape and Ecological Engineering, 16(2), 187-198. https://doi.org/10.1007/ s11355-020-00411-0

Moher, D., Liberati, A., Tetzlaff, J., \& Altman, D. G. (2009). Preferred Reporting Items for Systematic Reviews and Meta-Analyses: The PRISMA Statement. PLoS Medicine, 6(7), e1000097. https://doi. org/10.1371/journal.pmed.1000097

Montaud, J.-M., Pecastaing, N., \& Tankari, M. (2017). Potential socioeconomic implications of future climate change and variability for Nigerien agriculture: A countrywide dynamic CGE-Microsimulation analysis. Economic Modelling , 63, 128-142. https://doi.org/10.1016/j. econmod.2017.02.005

Muchuru, S., \& Nhamo, G. (2019). A review of climate change adaptation measures in the African crop sector. Climate and Development, 11(10), 873-885. https://doi.org/10.1080/17565529.2019.1585319

Mugambiwa, S. S., \& Tirivangasi, H. M. (2017). Climate change: A threat towards achieving 'Sustainable Development Goal number two' (end hunger, achieve food security and improved nutrition and promote sustainable agriculture) in South Africa. Jàmbá: Journal of Disaster Risk Studies, 9(1). https://doi.org/10.4102/jamba.v9i1.350

Müller, C. (2013). African Lessons on Climate Change Risks for Agriculture. Annual Review of Nutrition, 33(1), 395-411. https://doi.org/10.1146/ annurev-nutr-071812-161121

Muller, C., Cramer, W., Hare, W. L., \& Lotze-Campen, H. (2011). Climate change risks for African agriculture. Proceedings of the National Academy of Sciences, 108(11), 4313-4315. https://doi.org/10.1073/ pnas. 1015078108

Mundia, C. W., Secchi, S., Akamani, K., \& Wang, G. (2019). A Regional Comparison of Factors Affecting Global Sorghum Production: The Case of North America, Asia and Africa's Sahel. Sustainability, 11(7), 2135. https://doi.org/10.3390/su11072135

Mutuo, P. K., Cadisch, G., Albrecht, A., Palm, C. A., \& Verchot, L. (2005). 
Potential of agroforestry for carbon sequestration and mitigation of greenhouse gas emissions from soils in the tropics. Nutrient Cycling in Agroecosystems, 71(1), 43-54. https://doi.org/10.1007/ s10705-004-5285-6

Naah, J.-B. S. N., \& Braun, B. (2019). Local agro-pastoralists' perspectives on forage species diversity, habitat distributions, abundance trends and ecological drivers for sustainable livestock production in West Africa. Scientific Reports, 9(1), 1707. https://doi.org/10.1038/s41598019-38636-1

Naumann, G., Barbosa, P., Garrote, L., Iglesias, A., \& Vogt, J. (2014). Exploring drought vulnerability in Africa: an indicator based analysis to be used in early warning systems. Hydrology and Earth System Sciences, 18(5), 1591-1604. https://doi.org/10.5194/hess-18-15912014

Nelimor, Badu-Apraku, Tetteh, \& N'guetta. (2019). Assessment of Genetic Diversity for Drought, Heat and Combined Drought and Heat Stress Tolerance in Early Maturing Maize Landraces. Plants, 8(11), 518. https://doi.org/10.3390/plants8110518

Nielsen, J. Ø., \& Reenberg, A. (2010). Temporality and the problem with singling out climate as a current driver of change in a small West African village. Journal of Arid Environments, 74(4), 464-474. https:// doi.org/10.1016/j.jaridenv.2009.09.019

Niles, M. T., \& Brown, M. E. (2017). A multi-country assessment of factors related to smallholder food security in varying rainfall conditions. Scientific Reports, 7(1), 16277. https://doi.org/10.1038/s41598-01716282-9

Nkiaka, E., Taylor, A., Dougill, A. J., Antwi-Agyei, P., Fournier, N., Bosire, E. N., Konte, O., Lawal, K. A., Mutai, B., Mwangi, E., Ticehurst, H., Toure, A., $\&$ Warnaars, T. (2019). Identifying user needs for weather and climate services to enhance resilience to climate shocks in sub-Saharan Africa. Environmental Research Letters, 14(12), 123003. https://doi. org/10.1088/1748-9326/ab4dfe

Nkrumah, B. (2019). Africa's future: Demarginalizing urban agriculture in the era of climate change. Future of Food: Journal on Food, Agriculture and Society, 7(1), 8-20. https://doi.org/10.17170/kobra-2018122072

Nyboer, E. A., Liang, C., \& Chapman, L. J. (2019). Assessing the vulnerability of Africa's freshwater fishes to climate change: A continent-wide trait-based analysis. Biological Conservation, 236, 505-520. https:// doi.org/10.1016/j.biocon.2019.05.003

Odame Appiah, D., Akondoh, A. C. K., Tabiri, R. K., \& Donkor, A. A. (2018). Smallholder farmers' insight on climate change in rural Ghana. Cogent Food \& Agriculture, 4(1). https://doi.org/10.1080/23311932 2018.1436211

Ogundari, K., Ademuwagun, A. A., \& Ajao, O. A. (2017). Revisiting Environmental Kuznets Curve in Sub-Sahara Africa. International Journal of Social Economics, 44(2), 222-231. https://doi.org/10.1108/ IJSE-02-2015-0034

Oguntunde, P. G., Abiodun, B. J., \& Lischeid, G. (2017). Impacts of climate change on hydro-meteorological drought over the Volta Basin. West Africa. Global and Planetary Change, 155, 121-132. https://doi. org/10.1016/j.gloplacha.2017.07.003

Olayide, O. E., \& Alabi, T. (2018). Between rainfall and food poverty: Assessing vulnerability to climate change in an agricultural economy. Journal of Cleaner Production, 198, 1-10. https://doi.org/10.1016/j. jclepro.2018.06.221

Olusegun, C., Oguntunde, P., \& Gbobaniyi, E. (2018). Simulating the Impacts of Tree, C3, and C4 Plant Functional Types on the Future Climate of West Africa. Climate, 6(2), 35. https://doi.org/10.3390/cli6020035

Oluwatayo, I. B. (2019). Vulnerability and adaptive strategies of smallholder farmers to seasonal fluctuations in production and marketing in southwest Nigeria. Climate and Development, 11(8), 659-666. https:// doi.org/10.1080/17565529.2018.1521328

Onwutuebe, C. J. (2019). Patriarchy and Women Vulnerability to Adverse Climate Change in Nigeria. SAGE Open, 9(1), 215824401982591. https://doi.org/10.1177/2158244019825914

Onyutha, C. (2018a). Trends and variability in African long-term precipitation. Stochastic Environmental Research and Risk Assessment, 32(9), 2721-2739. https://doi.org/10.1007/s00477-018-1587-0

Onyutha, C. (2018b). African food insecurity in a changing climate: The roles of science and policy. Food and Energy Security, e00160. https:// doi.org/10.1002/fes3.160

Ouédraogo, M., Zougmoré, R., Moussa, A. S., Partey, S. T., Thornton, P. K., Kristjanson, P., Ndour, N. Y. B., Somé, L., Naab, J., Boureima, M., Diakité, L., \& Quiros, C. (2017). Markets and climate are driving rapid change in farming practices in Savannah West Africa. Regional Environmental Change, 17(2), 437-449. https://doi.org/10.1007/ s10113-016-1029-9

Oyekale, A. (2015). Access to Risk Mitigating Weather Forecasts and Changes in Farming Operations in East and West Africa: Evidence from a Baseline Survey. Sustainability, 7(11), 14599-14617. https:// doi.org/10.3390/su71114599

Paeth, H. (2011). Postprocessing of simulated precipitation for impact research in West Africa. Part I: model output statistics for monthly data. Climate Dynamics, 36(7-8), 1321-1336. https://doi.org/10.1007/ s00382-010-0760-z

Palazzo, A., Vervoort, J. M., Mason-D’Croz, D., Rutting, L., Havlík, P., Islam, S., Bayala, J., Valin, H., Kadi Kadi, H. A., Thornton, P., \& Zougmore, R. (2017). Linking regional stakeholder scenarios and shared socioeconomic pathways: Quantified West African food and climate futures in a global context. Global Environmental Change, 45, 227-242. https://doi.org/10.1016/j.gloenvcha.2016.12.002

Palm, C. A., Smukler, S. M., Sullivan, C. C., Mutuo, P. K., Nyadzi, G. I., \& Walsh, M. G. (2010). Identifying potential synergies and trade-offs for meeting food security and climate change objectives in sub-Saharan Africa. Proceedings of the National Academy of Sciences, 107(46), 19661-19666. https://doi.org/10.1073/pnas.0912248107

Parkes, B, Challinor, A., \& Nicklin, K. (2015). Crop failure rates in a geoengineered climate: impact of climate change and marine cloud brightening. Environmental Research Letters, 10(8), 084003. https:// doi.org/10.1088/1748-9326/10/8/084003

Parkes, Ben, Sultan, B., \& Ciais, P. (2018). The impact of future climate change and potential adaptation methods on Maize yields in West Africa. Climatic Change, 151(2), 205-217. https://doi.org/10.1007/ s10584-018-2290-3

Partey, S. T., Zougmoré, R. B., Ouédraogo, M., \& Campbell, B. M. (2018). Developing climate-smart agriculture to face climate variability in West Africa: Challenges and lessons learnt. Journal of Cleaner Production, 187, 285-295. https://doi.org/10.1016/j.jclepro.2018.03.199

Perez, C., Roncoli, C., Neely, C., \& Steiner, J. L. (2007). Can carbon sequestration markets benefit low-income producers in semi-arid Africa? Potentials and challenges. Agricultural Systems, 94(1), 2-12. https://doi.org/10.1016/j.agsy.2005.09.009

Petersen, S. O., Blanchard, M., Chadwick, D., Del Prado, A., Edouard, N., Mosquera, J., \& Sommer, S. G. (2013). Manure management for greenhouse gas mitigation. Animal, 7(s2), 266-282. https://doi. org/10.1017/S1751731113000736

Pironon, S., Etherington, T. R., Borrell, J. S., Kühn, N., Macias-Fauria, M. Ondo, I., Tovar, C., Wilkin, P., \& Willis, K. J. (2019). Potential adaptive strategies for 29 sub-Saharan crops under future climate change. Nature Climate Change, 9(10), 758-763. https://doi.org/10.1038/ s41558-019-0585-7

Powlson, D. S., Stirling, C. M., Thierfelder, C., White, R. P., \& Jat, M. L. (2016). Does conservation agriculture deliver climate change mitigation through soil carbon sequestration in tropical agro-ecosystems? Agriculture, Ecosystems \& Environment, 220, 164-174. https://doi. org/10.1016/.agee.2016.01.005

Prestele, R., \& Verburg, P. H. (2020). The overlooked spatial dimension of climate-smart agriculture. Global Change Biology, 26(3), 1045-1054. https://doi.org/10.1111/gcb.14940

Pricope, N. G., Husak, G., Lopez-Carr, D., Funk, C., \& Michaelsen, J. (2013). The climate-population nexus in the East African Horn: Emerging degradation trends in rangeland and pastoral livelihood zones. Global Environmental Change, 23(6), 1525-1541. https://doi.org/10.1016/j. gloenvcha.2013.10.002

Proud, S. R., \& Rasmussen, L. V. (2011). The influence of seasonal rainfall upon Sahel vegetation. Remote Sensing Letters, 2(3), 241-249. https://doi.org/10.1080/01431161.2010.515268

Pushpalatha, R., \& Gangadharan, B. (2020). Is Cassava (Manihot esculenta Crantz) a Climate "Smart" Crop? A Review in the Context of Bridging Future Food Demand Gap. Tropical Plant Biology. https://doi. org/10.1007/s12042-020-09255-2

Quintero, N. Y., \& Cohen, I. M. (2019). The Nexus between CO2 Emissions and Genetically Modified Crops: a Perspective from Order Theory. Environmental Modeling \& Assessment, 24(6), 641-658. https://doi. org/10.1007/s10666-019-09658-w

Raile, E. D., Young, L. M., Sarr, A., Mbaye, S., Raile, A. N. W., Wooldridge, L., Sanogo, D., \& Post, L. A. (2019). Political will and public will for climatesmart agriculture in Senegal. Journal of Agribusiness in Developing 
and Emerging Economies, 9(1), 44-62. https://doi.org/10.1108/ JADEE-01-2018-0003

Ramin, B. M., \& McMichael, A. J. (2009). Climate Change and Health in Sub-Saharan Africa: A Case-Based Perspective. EcoHealth, 6(1), 52-57. https://doi.org/10.1007/s10393-009-0222-4

Ramirez-Villegas, J., \& Challinor, A. (2012). Assessing relevant climate data for agricultural applications. Agricultural and Forest Meteorology, 161 , 26-45. https://doi.org/10.1016/j.agrformet.2012.03.015

Ramirez-Villegas, J., Jarvis, A., \& Läderach, P. (2013). Empirical approaches for assessing impacts of climate change on agriculture: The EcoCrop model and a case study with grain sorghum. Agricultural and Forest Meteorology, 170, 67-78. https://doi.org/10.1016/j. agrformet.2011.09.005

Rao, N. (2019). From abandonment to autonomy: Gendered strategies for coping with climate change, Isiolo County, Kenya. Geoforum, 102, 27-37. https://doi.org/10.1016/j.geoforum.2019.03.017

Rasmussen, L. V. (2018). Re-Defining Sahelian 'Adaptive Agriculture' when Implemented Locally: Beyond Techno-fix Solutions. World Development, 108, 274-282. https://doi.org/10.1016/j. worlddev.2017.03.034

Rasmussen, L. V., Mertz, O., Rasmussen, K., \& Nieto, H. (2015). Improving how meteorological information is used by pastoralists through adequate communication tools. Journal of Arid Environments, 121. 52-58. https://doi.org/10.1016/j.jaridenv.2015.05.001

Rasmussen, L. V., Mertz, O., Rasmussen, K., Nieto, H., Ali, A., \& Maiga, I. (2014). Weather, Climate, and Resource Information Should Meet the Needs of Sahelian Pastoralists. Weather, Climate, and Society, 6(4), 482-494. https://doi.org/10.1175/WCAS-D-14-00010.1

Rauch, M., Bliefernicht, J., Laux, P., Salack, S., Waongo, M., \& Kunstmann, H. (2019). Seasonal Forecasting of the Onset of the Rainy Season in West Africa. Atmosphere, 10(9), 528. https://doi. org/10.3390/atmos10090528

Rhodes, E. R., \& Atewamba, C. (2019). Climate Change Impact Chain Factors in ECOWAS. Journal of Agriculture and Environment for International Development, 113(1), 35-78. https://doi.org/10.12895/ jaeid.20191.916

Richardson, K. J., Lewis, K. H., Krishnamurthy, P. K., Kent, C., Wiltshire, A. J., \& Hanlon, H. M. (2018). Food security outcomes under a changing climate: impacts of mitigation and adaptation on vulnerability to food insecurity. Climatic Change, 147(1-2), 327-341. https://doi. org/10.1007/s10584-018-2137-y

Rigolot, C., de Voil, P., Douxchamps, S., Prestwidge, D., Van Wijk, M., Thornton, P. K., Rodriguez, D., Henderson, B., Medina, D., \& Herrero, M. (2017). Interactions between intervention packages, climatic risk, climate change and food security in mixed croplivestock systems in Burkina Faso. Agricultural Systems, 151, 217-224. https://doi.org/10.1016/j.agsy.2015.12.017

Ringius, L. (2002). Soil carbon sequestration and the CDM: Opportunities and challenges for Africa. Climatic Change, 54(4), 471-495. https:// doi.org/10.1023/A:1016108215242

Rippke, U., Ramirez-Villegas, J., Jarvis, A., Vermeulen, S. J., Parker, L., Mer, F., Diekkrüger, B., Challinor, A. J., \& Howden, M. (2016). Timescales of transformational climate change adaptation in subSaharan African agriculture. Nature Climate Change, 6(6), 605-609. https://doi.org/10.1038/nclimate2947

Roncoli, C., Ingram, K., \& Kirshen, P. (2001). The costs and risks of coping with drought: livelihood impacts and farmers' responses in Burkina Faso. Climate Research, 19, 119-132. https://doi.org/10.3354/ cr019119

Rosenthal, D. M., \& Ort, D. R. (2012). Examining Cassava's Potential to Enhance Food Security under Climate Change. Tropical Plant Biology, 5(1), 30-38. https://doi.org/10.1007/s12042-011-9086-1

Roudier, P., Sultan, B., Quirion, P., \& Berg, A. (2011). The impact of future climate change on West African crop yields: What does the recent literature say? Global Environmental Change, 21(3), 1073-1083. https://doi.org/10.1016/j.gloenvcha.2011.04.007

Rudi, L.-M., Azadi, H., \& Witlox, F. (2012). Reconcilability of Socio-Economic Development and Environmental Conservation in Sub-Saharan Africa. Global and Planetary Change, 86-87, 1-10. https://doi.org/10.1016/j. gloplacha.2011.12.004

Ruf, F., Schroth, G., \& Doffangui, K. (2015). Climate change, cocoa migrations and deforestation in West Africa: What does the past tell us about the future? Sustainability Science, 10(1), 101-111. https:// doi.org/10.1007/s11625-014-0282-4
Sachs, J., Schmidt-Traub, G., Kroll, C., Durand-Delacre, D., \& Teksoz, K (2017). SDG Index and Dashboards Report 2017. https://doi. org/10.1016/S0140-6736(09)61513-0

Salack, S, Sarr, B., Sangare, S., Ly, M., Sanda, I., \& Kunstmann, H. (2015). Crop-climate ensemble scenarios to improve risk assessment and resilience in the semi-arid regions of West Africa. Climate Research, 65, 107-121. https://doi.org/10.3354/cr01282

Salack, Seyni, Klein, C., Giannini, A., Sarr, B., Worou, O. N., Belko, N., Jan Bliefernicht, \& Kunstman, H. (2016). Global warming induced hybrid rainy seasons in the Sahel. Environmental Research Letters, 11(10), 104008. https://doi.org/10.1088/1748-9326/11/10/104008

Salinger, M. J., Sivakumar, M. V. K., \& Motha, R. (2005). Reducing Vulnerability of Agriculture and Forestry to Climate Variability and Change: Workshop Summary and Recommendations. Climatic Change, 70(1-2), 341-362. https://doi.org/10.1007/s10584-0055954-8

Salmon, G. R., Marshall, K., Tebug, S. F., Missohou, A., Robinson, T. P., \& MacLeod, M. (2018). The greenhouse gas abatement potential of productivity improving measures applied to cattle systems in a developing region. Animal, 12(4), 844-852. https://doi.org/10.1017/ S1751731117002294

Sanfo, S., Fonta, W. M., Diasso, U. J., Nikiéma, M. P., Lamers, J. P. A., \& Tondoh, J. E. (2017). Climate- and Environment-Induced Intervillage Migration in Southwestern Burkina Faso, West Africa. Weather, Climate, and Society, 9(4), 823-837. https://doi.org/10.1175/ WCAS-D-16-0065.1

Sarr, B. (2012). Present and future climate change in the semi-arid region of West Africa: a crucial input for practical adaptation in agriculture. Atmospheric Science Letters, 13(2), 108-112. https://doi.org/10.1002/ asl.368

Scheiter, S., \& Savadogo, P. (2016). Ecosystem management can mitigate vegetation shifts induced by climate change in West Africa. Ecological Modelling, 332, 19-27. https://doi.org/10.1016/j. ecolmodel.2016.03.022

Schlenker, W., \& Lobell, D. B. (2010). Robust negative impacts of climate change on African agriculture. Environmental Research Letters, 5(1), 014010. https://doi.org/10.1088/1748-9326/5/1/014010

Seo, S. N. (2014). Evaluation of the Agro-Ecological Zone methods for the study of climate change with micro farming decisions in sub-Saharan Africa. European Journal of Agronomy, 52, 157-165. https://doi. org/10.1016/j.eja.2013.09.014

Seo, S. N., Mendelsohn, R., Dinar, A., \& Kurukulasuriya, P. (2009). Adapting to Climate Change Mosaically: An Analysis of African Livestock Management by Agro-Ecological Zones. The B.E. Journal of Economic Analysis \& Policy, 9(2). https://doi.org/10.2202/1935-1682.1955

Serdeczny, O., Adams, S., Baarsch, F., Coumou, D., Robinson, A., Hare, W., Schaeffer, M., Perrette, M., \& Reinhardt, J. (2017). Climate change impacts in Sub-Saharan Africa: from physical changes to their social repercussions. Regional Environmental Change, 17(6), 1585-1600. https://doi.org/10.1007/s10113-015-0910-2

Serpantié, G., Dorée, A., Fusillier, J.-L., Moity-Maizi, P., Lidon, B. Douanio, M., Sawadogo, A., Bossa, A. Y., \& Hounkpè, J. (2019). Nouveaux risques dans les bas-fonds des terroirs soudaniens. Une étude de cas au Burkina Faso. Cahiers Agricultures, 28, 19. https:// doi.org/10.1051/cagri/2019020

Shcherbak, I., Millar, N., \& Robertson, G. P. (2014). Global metaanalysis of the nonlinear response of soil nitrous oxide (N2O) emissions to fertilizer nitrogen. Proceedings of the National Academy of Sciences, 111(25), 9199-9204. https://doi.org/10.1073/pnas.1322434111

Sheffield, J., Wood, E. F., Chaney, N., Guan, K., Sadri, S., Yuan, X., Olang, L., Amani, A., Ali, A., Demuth, S., \& Ogallo, L. (2014). A Drought Monitoring and Forecasting System for Sub-Sahara African Water Resources and Food Security. Bulletin of the American Meteorological Society, 95(6), 861-882. https://doi.org/10.1175/BAMS-D-12-00124.1

Shi, W., \& Tao, F. (2014). Vulnerability of African maize yield to climate change and variability during 1961-2010. Food Security, 6(4), 471-481. https://doi.org/10.1007/s12571-014-0370-4

Sidibe, M., Dieppois, B., Eden, J., Mahé, G., Paturel, J.-E., Amoussou, E., Anifowose, B., \& Lawler, D. (2019). Interannual to Multi-decadal streamflow variability in West and Central Africa: Interactions with catchment properties and large-scale climate variability. Global and Planetary Change, 177, 141-156. https://doi.org/10.1016/j. gloplacha.2019.04.003

Sidibé, Y., Foudi, S., Pascual, U., \& Termansen, M. (2018). Adaptation to 
Climate Change in Rainfed Agriculture in the Global South: Soil Biodiversity as Natural Insurance. Ecological Economics, 146. 588-596. https://doi.org/10.1016/j.ecolecon.2017.12.017

Siebert, A. (2016). Analysis of Index Insurance Potential for Adaptation to Hydroclimatic Risks in the West African Sahel. Weather, Climate, and Society, 8(3), 265-283. https://doi.org/10.1175/WCAS-D-15-0040.1

Sileshi, G. W., Gebeyehu, S., \& Mafongoya, P. L. (2019). The threat of alien invasive insect and mite species to food security in Africa and the need for a continent-wide response. Food Security, 11(4), 763-775. https://doi.org/10.1007/s12571-019-00930-1

Sissoko, K., van Keulen, H., Verhagen, J., Tekken, V., \& Battaglini, A. (2011). Agriculture, livelihoods and climate change in the West African Sahel. Regional Environmental Change, 11(S1), 119-125. https://doi. org/10.1007/s10113-010-0164-y

Snapp, S. S., Cox, C. M., \& Peter, B. G. (2019). Multipurpose legumes for smallholders in sub-Saharan Africa: Identification of promising 'scale out' options. Global Food Security, 23, 22-32. https://doi. org/10.1016/j.gfs.2019.03.002

Sonwa, D. J., Dieye, A., El Mzouri, E.-H., Majule, A., Mugabe, F. T., Omolo, N., Wouapi, H., Obando, J., \& Brooks, N. (2017). Drivers of climate risk in African agriculture. Climate and Development, 9(5), 383-398. https://doi.org/10.1080/17565529.2016.1167659

Sorgho, R., Franke, J., Simboro, S., Phalkey, R., \& Saeurborn, R. (2016). NUTRItion and CLIMate (NUTRICLIM): investigating the relationship between climate variables and childhood malnutrition through agriculture, an exploratory study in Burkina Faso. Public Health Reviews, 37(1), 16. https://doi.org/10.1186/s40985-016-0031-6

Sossa, A., Liebmann, B., Bladé, I., Allured, D., Hendon, H. H., Peterson, P., \& Hoell, A. (2017). Statistical Connection between the Madden-Julian Oscillation and Large Daily Precipitation Events in West Africa. Journal of Climate, 30(6), 1999-2010. https://doi.org/10.1175/ JCLI-D-16-0144.1

Srivastava, A. K., Mboh, C. M., Zhao, G., Gaiser, T., \& Ewert, F. (2018). Climate change impact under alternate realizations of climate scenarios on maize yield and biomass in Ghana. Agricultural Systems, 159, 157-174. https://doi.org/10.1016/j.agsy.2017.03.011

Steffen, W., Richardson, K., Rockstrom, J., Cornell, S. E., Fetzer, I., Bennett, E. M., Biggs, R., Carpenter, S. R., de Vries, W., de Wit, C. A., Folke, C., Gerten, D., Heinke, J., Mace, G. M., Persson, L. M., Ramanathan, V., Reyers, B., \& Sorlin, S. (2015). Planetary boundaries: Guiding human development on a changing planet. Science, 347(6223), 1259855-1259855. https://doi.org/10.1126/science.1259855

Steward, P. R., Dougill, A. J., Thierfelder, C., Pittelkow, C. M., Stringer, L. C., Kudzala, M., \& Shackelford, G. E. (2018). The adaptive capacity of maize-based conservation agriculture systems to climate stress in tropical and subtropical environments: A meta-regression of yields. Agriculture, Ecosystems \& Environment, 251, 194-202. https://doi. org/10.1016/j.agee.2017.09.019

Stith, M., Giannini, A., Corral, J. del, Adamo, S., \& de Sherbinin, A. (2016). A Quantitative Evaluation of the Multiple Narratives of the Recent Sahelian Regreening. Weather, Climate, and Society, 8(1), 67-83. https://doi.org/10.1175/WCAS-D-15-0012.1

Suckall, N., Stringer, L. C., \& Tompkins, E. L. (2015). Presenting TripleWins? Assessing Projects That Deliver Adaptation, Mitigation and Development Co-benefits in Rural Sub-Saharan Africa. AMBIO, 44(1), 34-41. https://doi.org/10.1007/s13280-014-0520-0

Sultan, B., Roudier, P., Quirion, P., Alhassane, A., Muller, B., Dingkuhn, M., Ciais, P., Guimberteau, M., Traore, S., \& Baron, C. (2013). Assessing climate change impacts on sorghum and millet yields in the Sudanian and Sahelian savannas of West Africa. Environmental Research Letters, 8(1), 1-9. https://doi.org/10.1088/1748-9326/8/1/014040

Sultan, B, Guan, K., Kouressy, M., Biasutti, M., Piani, C., Hammer, G. L., McLean, G., \& Lobell, D. B. (2014). Robust features of future climate change impacts on sorghum yields in West Africa. Environmental Research Letters, 9(10), 104006. https://doi.org/10.1088/17489326/9/10/104006

Sultan, Benjamin, Defrance, D., \& lizumi, T. (2019). Evidence of crop production losses in West Africa due to historical global warming in two crop models. Scientific Reports, 9(1), 12834. https://doi. org/10.1038/s41598-019-49167-0

Sultan, Benjamin, \& Gaetani, M. (2016). Agriculture in West Africa in the Twenty-First Century: Climate Change and Impacts Scenarios, and Potential for Adaptation. Frontiers in Plant Science, 7, e1262. https:// doi.org/10.3389/fpls.2016.01262
Sultan, Benjamin, Parkes, B., \& Gaetani, M. (2019). Direct and indirect effects of CO 2 increase on crop yield in West Africa. International Journal of Climatology, 39(4), 2400-2411. https://doi.org/10.1002/ joc. 5960

Sylla, M. B., Faye, A., Klutse, N. A. B., \& Dimobe, K. (2018a). Projected increased risk of water deficit over major West African river basins under future climates. Climatic Change, 151(2), 247-258. https://doi. org/10.1007/s10584-018-2308-x

Sylla, M. B., Giorgi, F., Pal, J. S., Gibba, P., Kebe, I., \& Nikiema, M. (2015). Projected Changes in the Annual Cycle of High-Intensity Precipitation Events over West Africa for the Late Twenty-First Century. Journal of Climate, 28(16), 6475-6488. https://doi.org/10.1175/ JCLI-D-14-00854.1

Sylla, M. B., Pal, J. S., Faye, A., Dimobe, K., \& Kunstmann, H. (2018b). Climate change to severely impact West African basin scale irrigation in $2{ }^{\circ} \mathrm{C}$ and $1.5^{\circ} \mathrm{C}$ global warming scenarios. Scientific Reports, 8(1), 14395. https://doi.org/10.1038/s41598-018-32736-0

Tabeau, A., van Meijl, H., Overmars, K. P., \& Stehfest, E. (2017). REDD policy impacts on the agri-food sector and food security. Food Policy, 66, 73-87. https://doi.org/10.1016/j.foodpol.2016.11.006

Takimoto, A., Nair, P. K. R., \& Nair, V. D. (2008). Carbon stock and sequestration potential of traditional and improved agroforestry systems in the West African Sahel. Agriculture, Ecosystems \& Environment, 125(1-4), 159-166. https://doi.org/10.1016/j.agee.2007.12.010

Tankari, M. R. (2020). Rainfall variability and farm households' food insecurity in Burkina Faso: nonfarm activities as a coping strategy. Food Security, 12, 567-578. https://doi.org/10.1007/s12571-01901002-0

Taylor, C. M., Lambin, E. F., Stephenne, N., Harding, R. J., \& Essery, R. L. H. (2002). The Influence of Land Use Change on Climate in the Sahel. Journal of Climate, 15(24), 3615-3629. https://doi.org/10.1175/15200442(2002)015<3615:TIOLUC > 2.0.CO;2

Terdoo, F., \& Feola, G. (2016). The Vulnerability of Rice Value Chains in SubSaharan Africa: A Review. Climate, 4(3), 47. https://doi.org/10.3390/ cli4030047

Tesfaye, K., Gbegbelegbe, S., Cairns, J. E., Shiferaw, B., Prasanna, B. M. Sonder, K., Boote, K., Makumbi, D., \& Robertson, R. (2015). Maize systems under climate change in sub-Saharan Africa. International Journal of Climate Change Strategies and Management, 7(3), 247-271. https://doi.org/10.1108/IJCCSM-01-2014-0005

Thiaw, M., Auger, P.-A., Ngom, F., Brochier, T., Faye, S., Diankha, O., \& Brehmer, P. (2017). Effect of environmental conditions on the seasonal and inter-annual variability of small pelagic fish abundance off NorthWest Africa: The case of both Senegalese sardinella. Fisheries Oceanography, 26(5), 583-601. https://doi.org/10.1111/fog.12218

Thierfelder, C., Baudron, F., Setimela, P., Nyagumbo, I., Mupangwa, W., Mhlanga, B., Lee, N., \& Gérard, B. (2018). Complementary practices supporting conservation agriculture in southern Africa. A review. Agronomy for Sustainable Development, 38(2), 16. https://doi. org/10.1007/s13593-018-0492-8

Thomas, N., \& Nigam, S. (2018). Twentieth-Century Climate Change over Africa: Seasonal Hydroclimate Trends and Sahara Desert Expansion. Journal of Climate, 31(9), 3349-3370. https://doi.org/10.1175/ JCLI-D-17-0187.1

Thornton, P. K., \& Herrero, M. (2014). Climate change adaptation in mixed crop-livestock systems in developing countries. Global Food Security, 3(2), 99-107. https://doi.org/10.1016/j.gfs.2014.02.002

Thornton, P. K., \& Herrero, M. (2015). Adapting to climate change in the mixed crop and livestock farming systems in sub-Saharan Africa. Nature Climate Change, 5(9), 830-836. https://doi.org/10.1038/ nclimate2754

Thornton, P. K., Jones, P. G., Ericksen, P. J., \& Challinor, A. J. (2011). Agriculture and food systems in sub-Saharan Africa in a $4{ }^{\circ} \mathrm{C}+$ world Philosophical Transactions of the Royal Society A: Mathematical, Physical and Engineering Sciences, 369(1934), 117-136. https://doi. org/10.1098/rsta.2010.0246

Tittonell, P., Scopel, E., Andrieu, N., Posthumus, H., Mapfumo, P., Corbeels, M., van Halsema, G. E., Lahmar, R., Lugandu, S., Rakotoarisoa, J., Mtambanengwe, F., Pound, B., Chikowo, R., Naudin, K., Triomphe, B., \& Mkomwa, S. (2012). Agroecology-based aggradation-conservation agriculture (ABACO): Targeting innovations to combat soil degradation and food insecurity in semi-arid Africa. Field Crops Research, 132, 168-174. https://doi.org/10.1016/j. fcr.2011.12.011 
Torquebiau, E. (2017). Le changement climatique, un défi pour la recherche : I'exemple de l'initiative " $4 \%$ ". OCL, 24(1), 108. https:// doi.org/10.1051/ocl/2016054

Totin, E., Segnon, A., Schut, M., Affognon, H., Zougmoré, R., Rosenstock, T., \& Thornton, P. (2018). Institutional Perspectives of Climate-Smart Agriculture: A Systematic Literature Review. Sustainability, 10(6), 1990. https://doi.org/10.3390/su10061990

Traoré, S. B., Alhassane, A., Muller, B., Kouressy, M., Somé, L., Sultan, B., Oettli, P., Siéné Laopé, A. C., Sangaré, S., Vaksmann, M., Diop, M., Dingkhun, M., \& Baron, C. (2011). Characterizing and modeling the diversity of cropping situations under climatic constraints in West Africa. Atmospheric Science Letters, 12(1), 89-95. https://doi. org/10.1002/asl.295

Traore, S., \& Owiyo, T. (2013). Dirty droughts causing loss and damage in Northern Burkina Faso. International Journal of Global Warming , 5(4), 498. https://doi.org/10.1504/IJGW.2013.057288

Trnka, M., Feng, S., Semenov, M. A., Olesen, J. E., Kersebaum, K. C., Rötter, R. P., Semerádová, D., Klem, K., Huang, W., Ruiz-Ramos, M., Hlavinka, P., Meitner, J., Balek, J., Havlík, P., \& Büntgen, U. (2019). Mitigation efforts will not fully alleviate the increase in water scarcity occurrence probability in wheat-producing areas. Science Advances, 5(9), e2406. https://doi.org/10.1126/sciadv.aau2406

Ugbaje, S. U., Odeh, I. O. A., \& Bishop, T. F. A. (2019). Fuzzy measure-based multicriteria land assessment for rainfed maize in West Africa for the current and a range of plausible future climates. Computers and Electronics in Agriculture, 158, 51-67. https://doi.org/10.1016/j. compag.2019.01.011

UNDP. (2019). Human Development Report 2019. http://hdr.undp.org/sites/ default/files/hdr2019.pdf

United Nations. (2015). Transforming Our World: The 2030 Agenda for Sustainable Development. Resolution adopted by the General Assembly on 25 September 2015. http://www.un.org/ga/search/ view_doc.asp?symbol=A/RES/70/1\&Lang $=\mathrm{E}$

USAID. (2017). Climate Change Risk in West Africa Sahel: Regional Fact Sheet. https://www.climatelinks.org/sites/default/files/asset/ document/2017 April_USAID ATLAS_Climate Change Risk Profile - Sahel.pdf

USAID. (2018). Burkina Faso: Nutrition Profile. https://www.usaid.gov/ sites/default/files/documents/1864/Burkina-Faso-Nutrition-ProfileMar2018-508.pdf

Vågen, T.-G., Lal, R., \& Singh, B. R. (2005). Soil carbon sequestration in sub-Saharan Africa: a review. Land Degradation \& Development, 16(1), 53-71. https://doi.org/10.1002/ldr.644

van Beek, C. L., Meerburg, B. G., Schils, R. L. M., Verhagen, J., \& Kuikman, P. J. (2010). Feeding the world's increasing population while limiting climate change impacts: linking N2O and $\mathrm{CH} 4$ emissions from agriculture to population growth. Environmental Science \& Policy, 13(2), 89-96. https://doi.org/10.1016/j.envsci.2009.11.001

van der Land, V., \& Hummel, D. (2013). Vulnerability and the Role of Education in Environmentally Induced Migration in Mali and Senegal. Ecology and Society, 18(4), https://doi.org/10.5751/ES-0583018041414

van Loon, M. P., Hijbeek, R., Berge, H. F. M., De Sy, V., Broeke, G. A., Solomon, D., \& Ittersum, M. K. (2019). Impacts of intensifying or expanding cereal cropping in sub-Saharan Africa on greenhouse gas emissions and food security. Global Change Biology, 25(11), 3720-3730. https://doi.org/10.1111/gcb.14783

van Oort, P. A. J., \& Zwart, S. J. (2018). Impacts of climate change on rice production in Africa and causes of simulated yield changes. Global Change Biology, 24(3), 1029-1045. https://doi.org/10.1111/gcb.13967

van Wesenbeeck, C. F. A., Sonneveld, B. G. J. S., \& Voortman, R. L. (2016). Localization and characterization of populations vulnerable to climate change: Two case studies in Sub-Saharan Africa. Applied Geography, 66, 81-91. https://doi.org/10.1016/j.apgeog.2015.11.001

Vaughan, C., Hansen, J., Roudier, P., Watkiss, P., \& Carr, E. (2019). Evaluating agricultural weather and climate services in Africa: Evidence, methods, and a learning agenda. Wiley Interdisciplinary Reviews: Climate Change, e586. https://doi.org/10.1002/wcc.586

vom Brocke, K., Trouche, G., Weltzien, E., Kondombo-Barro, C. P., Sidibé, A., Zougmoré, R., \& Gozé, E. (2014). Helping Farmers Adapt to Climate and Cropping System Change Through Increased Access to Sorghum Genetic Resources Adapted to Prevalent Sorghum Cropping Systems in Burkina Faso. Experimental Agriculture, 50(2), 284-305. https://doi. org/10.1017/S0014479713000616 von Uexkull, N. (2014). Sustained drought, vulnerability and civil conflict in Sub-Saharan Africa. Political Geography, 43, 16-26. https://doi. org/10.1016/j.polgeo.2014.10.003

von Uexkull, N., Croicu, M., Fjelde, H., \& Buhaug, H. (2016). Civil conflict sensitivity to growing-season drought. Proceedings of the National Academy of Sciences, 113(44), 12391-12396. https://doi.org/10.1073/ pnas. 1607542113

Vrieling, A., de Beurs, K. M., \& Brown, M. E. (2008). Recent trends in agricultural production of Africa based on AVHRR NDVI time series. In C. M. U. Neale, M. Owe \& G. D'Urso (Eds.), Conference on Remote Sensing for Agriculture, Ecosystems, and Hydrology - 15th International Symposium on Remote Sensing (p. 71040R). SPIE Europe. https://doi.org/10.1117/12.799824

Vrieling, A., de Leeuw, J., \& Said, M. (2013). Length of Growing Period over Africa: Variability and Trends from 30 Years of NDVI Time Series. Remote Sensing , 5(2), 982-1000. https://doi.org/10.3390/rs5020982

Waha, K., Müller, C., Bondeau, A., Dietrich, J. P., Kurukulasuriya, P. Heinke, J., \& Lotze-Campen, H. (2013a). Adaptation to climate change through the choice of cropping system and sowing date in sub-Saharan Africa. Global Environmental Change, 23(1), 130-143. https://doi.org/10.1016/j.gloenvcha.2012.11.001

Waha, K., Müller, C., \& Rolinski, S. (2013b). Separate and combined effects of temperature and precipitation change on maize yields in subSaharan Africa for mid- to late-21st century. Global and Planetary Change, 106, 1-12. https://doi.org/10.1016/j.gloplacha.2013.02.009

Waha, Katharina, Zipf, B., Kurukulasuriya, P., \& Hassan, R. M. (2016). An agricultural survey for more than 9,500 African households. Scientific Data, 3(1), 160020. https://doi.org/10.1038/sdata.2016.20

Wang, G. (2005). Agricultural drought in a future climate: results from 15 global climate models participating in the IPCC 4th assessment. Climate Dynamics, 25(7-8), 739-753. https://doi.org/10.1007/ s00382-005-0057-9

Wang, G., Ahmed, K. F., You, L., Yu, M., Pal, J., \& Ji, Z. (2017). Projecting regional climate and cropland changes using a linked biogeophysical-socioeconomic modeling framework: 1. Model description and an equilibrium application over West Africa. Journal of Advances in Modeling Earth Systems, 9(1), 354-376. https://doi. org/10.1002/2016MS000712

Waongo, M., Laux, P., \& Kunstmann, H. (2015). Adaptation to climate change: The impacts of optimized planting dates on attainable maize yields under rainfed conditions in Burkina Faso. Agricultural and Forest Meteorology, 205, 23-39. https://doi.org/10.1016/j. agrformet.2015.02.006

Waongo, M., Laux, P., Traoré, S. B., Sanon, M., \& Kunstmann, H. (2014). A Crop Model and Fuzzy Rule Based Approach for Optimizing Maize Planting Dates in Burkina Faso, West Africa. Journal of Applied Meteorology and Climatology, 53(3), 598-613. https://doi. org/10.1175/JAMC-D-13-0116.1

Ward, P. S., Florax, R. J. G. M., \& Flores-Lagunes, A. (2014). Climate change and agricultural productivity in Sub-Saharan Africa: a spatial sample selection model. European Review of Agricultural Economics, 41(2), 199-226. https://doi.org/10.1093/erae/jbt025

Webber, H., Gaiser, T., \& Ewert, F. (2014). What role can crop models play in supporting climate change adaptation decisions to enhance food security in Sub-Saharan Africa? Agricultural Systems, 127, 161-177. https://doi.org/10.1016/j.agsy.2013.12.006

Webersik, C., \& Wilson, C. (2009). Achieving environmental sustainability and growth in Africa: the role of science, technology and innovation. Sustainable Development, 17(6), 400-413. https://doi.org/10.1002/ sd.411

West, C. T., Roncoli, C., \& Ouattara, F. (2008). Local perceptions and regional climate trends on the Central Plateau of Burkina Faso. Land Degradation \& Development, 19(3), 289-304. https://doi.org/10.1002/ Idr.842

Wiederkehr, C., Beckmann, M., \& Hermans, K. (2018). Environmental change, adaptation strategies and the relevance of migration in SubSaharan drylands. Environmental Research Letters, 13(11), 113003 https://doi.org/10.1088/1748-9326/aae6de

Wilcox, B. A., Echaubard, P., de Garine-Wichatitsky, M., \& Ramirez, B. (2019). Vector-borne disease and climate change adaptation in African dryland social-ecological systems. Infectious Diseases of Poverty, 8(1), 36. https://doi.org/10.1186/s40249-019-0539-3

Williams, P. A., Crespo, O., Abu, M., \& Simpson, N. P. (2018). A systematic review of how vulnerability of smallholder agricultural systems to 
changing climate is assessed in Africa. Environmental Research Letters, 13(10), 103004. https://doi.org/10.1088/1748-9326/aae026

Witmer, F. D., Linke, A. M., O'Loughlin, J., Gettelman, A., \& Laing, A. (2017). Subnational violent conflict forecasts for sub-Saharan Africa, 2015-65, using climate-sensitive models. Journal of Peace Research, 54(2), 175-192. https://doi.org/10.1177/0022343316682064

Wittig, R., König, K., Schmidt, M., \& Szarzynski, J. (2007). A study of climate change and anthropogenic impacts in West Africa. Environmental Science and Pollution Research - International, 14(3), 182-189. https:// doi.org/10.1065/espr2007.02.388

Wood, S. A., Jina, A. S., Jain, M., Kristjanson, P., \& DeFries, R. S. (2014). Smallholder farmer cropping decisions related to climate variability across multiple regions. Global Environmental Change, 25, 163-172. https://doi.org/10.1016/j.gloenvcha.2013.12.011

World Bank. (2019). World Bank Open Data. https://data.worldbank.org

Worou, O. N., Tondoh, J. E., Koné, A. W., Gaiser, T., Guéi, A. M., \& Edoukou, F. E. (2019). Conventional versus agro-ecological intensification: assessing the effect of conservation agriculture in maize cropping systems with the DSSAT model in Côte d'Ivoire (West Africa). Regional Environmental Change, 19(6), 1725-1736. https://doi. org/10.1007/s10113-019-01511-w

Yamegueu, D., Alokore, Y., \& Corso, G. (2019). Potential of microfinanced solar water pumping systems for irrigation in rural areas of Burkina Faso. Energy, Sustainability and Society, 9(1), 8. https://doi. org/10.1186/s13705-019-0190-7

Yang, H., Faramarzi, M., \& Abbaspour, K. C. (2013). Assessing freshwater availability in Africa under the current and future climate with focus on drought and water scarcity. In J. Piantadosi, R. Anderssen, \& J. Boland (Eds.), 20th International Congress on Modelling and Simulation (MODSIM) (pp. 2994-3000). Modelling and Simulation Society of Australia and New Zealand (MSSANZ), Inc. https://doi. org/10.36334/modsim.2013.L16.yang

Zabel, F., Delzeit, R., Schneider, J. M., Seppelt, R., Mauser, W., \& Václavík, T. (2019). Global impacts of future cropland expansion and intensification on agricultural markets and biodiversity. Nature Communications, 10(1), 2844. https://doi.org/10.1038/s41467-01910775-z

Zampaligré, N., Dossa, L. H., \& Schlecht, E. (2014). Climate change and variability: perception and adaptation strategies of pastoralists and agro-pastoralists across different zones of Burkina Faso. Regional Environmental Change, 14(2), 769-783. https://doi.org/10.1007/ s10113-013-0532-5
Zampaligré, N., \& Fuchs, L. E. (2019). Determinants of Adoption of Multiple Climate-Smart Adaptation Practices in Sudano-Sahelian Pastoral and Agro-Pastoral Production Systems. Sustainability, 11(18), 4831 https://doi.org/10.3390/su11184831

Zhang, L., Traore, S., Ge, J., Li, Y., Wang, S., Zhu, G., Cui, Y., \& Fipps, G. (2019). Using boosted tree regression and artificial neural networks to forecast upland rice yield under climate change in Sahel. Computers and Electronics in Agriculture, 166, 105031. https://doi.org/10.1016/j. compag.2019.105031

Zidouemba, P. R. (2017). Economy-wide implications of climate change in Burkina Faso. Economics Bulletin, 37(4), 1-13.

Zomer, R. J., Trabucco, A., Bossio, D. A., \& Verchot, L. V. (2008). Climate change mitigation: A spatial analysis of global land suitability for clean development mechanism afforestation and reforestation. Agriculture, Ecosystems \& Environment, 126(1-2), 67-80. https:// doi.org/10.1016/j.agee.2008.01.014

Zorom, M., Barbier, B., Mertz, O., \& Zoungrana, T. P. (2010). Coping strategies of rural sahel to climate variability: Analysis of diversity. In E. Servat, S. Demuth, A. Dezetter, \& T. Daniell (Eds.), 6th World FRIEND Conference on Global Change: Facing Risks and Threats to Water Resources (pp. 286-293). International Association of Hydrological Sciences (IAHS).

Zorom, Malicki, Barbier, B., Mertz, O., \& Servat, E. (2013). Diversification and adaptation strategies to climate variability: A farm typology for the Sahel. Agricultura/Systems, 116, 7-15. https://doi.org/10.1016/j. agsy.2012.11.004

Zougmoré, R. B., Partey, S. T., Ouédraogo, M., Torquebiau, E., \& Campbell, B. M. (2018). Facing climate variability in sub-Saharan Africa: analysis of climate-smart agriculture opportunities to manage climate-related risks. Cahiers Agricultures, 27(3), 34001. https://doi. org/10.1051/cagri/2018019

Zougmoré, R. B., Partey, S. T., Totin, E., Ouédraogo, M., Thornton, P., Karbo, N., Sogoba, B., Dieye, B., \& Campbell, B. M. (2019). Sciencepolicy interfaces for sustainable climate-smart agriculture uptake: lessons learnt from national science-policy dialogue platforms in West Africa. International Journal of Agricultural Sustainability, 17(5), 367-382. https://doi.org/10.1080/14735903.2019.1670934

Zouré, C., Queloz, P., Koïta, M., Niang, D., Fowé, T., Yonaba, R. Consuegra, D., Yacouba, H., \& Karambiri, H. (2019). Modelling the water balance on farming practices at plot scale: Case study of Tougou watershed in Northern Burkina Faso. CATENA, 173, 59-70. https://doi.org/10.1016/j.catena.2018.10.002 


\section{APPENDIX}

Appendix 1: Geographical focus of research on the relationships between climate change and agriculture dealing with Burkina Faso

\begin{tabular}{cc}
\hline Geographical focus & $\begin{array}{c}\text { Number of selected } \\
\text { documents }\end{array}$ \\
\hline
\end{tabular}

Burkina Faso

50

Ayantunde et al. (2020); Barbier et al. (2009); Belem and Saqalli (2017); Belesova

et al. (2019); Borona et al. (2016); Bostick et al. (2007); Bunclark et al. (2018);

Coulibaly et al. (2014); D'haen et al. (2014); Di Leo et al. (2016); Dimobe et al. (2018);

Fonta et al. (2015); Gahi et al. (2015); Gaisberger et al. (2017); Groten and Ocatre (2002); Hänke et al. (2016); Henderson et al. (2018); Heubes et al. (2013); Ingram et al. (2002); Jahel et al. (2017); Kalame et al. (2011); Kima et al. (2014); Kima et al. (2015); Kniveton et al. (2012); Lay et al. (2009); Lodoun et al. (2014); Mande et al. (2015); Mishra et al. (2008); Nielsen and Reenberg (2010); Rasmussen (2018); Rasmussen et al. (2014); Rasmussen et al. (2015); Rigolot et al. (2017); Roncoli et al. (2001); Sanfo et al. (2017); Serpantié et al. (2019); Sorgho et al. (2016); Tankari (2020); Traore and Owiyo (2013); vom Brocke et al. (2014); Waongo et al. (2014); Waongo et al. (2015); West et al. (2008); Wittig et al. (2007); Zampaligré and Fuchs (2019); Zampaligré et al. (2014); Zhang et al. (2019); Zidouemba (2017); Zorom et al. (2013); Zouré et al. (2019) Ahmed et al. (2015); Ahmed et al. (2016); Andam-Akorful et al. (2017); Arthur and Baidoo (2011); Asare-Kyei et al. (2017); Bayala et al. (2014); Belem et al. (2011); Berthou et al. (2019); Bhaduri et al. (2011); Bicher and Diedhiou (2018); Boansi et al. (2017); Boansi et al. (2019); Brockhaus et al. (2012); Busby et al. (2014); Callo-Concha (2016); Callo-Concha (2018); Defrance et al. (2017); Douxchamps et al. (2016); Egbebiyi et al. (2019); Egbebiyi et al. (2019); Egbendewe et al. (2017); Faye et al. (2018); Ferner et al. (2018); Garnot et al. (2018); Guan et al. (2015); Guan et al. (2017); Haussmann et al. (2012); Johnson and Brown (2014); Jung et al. (2012); Klutse et al. (2018); Lahmar et al. (2012); Lambin et al. (2014); Lokonon et al. (2019); Luedeling and Neufeldt (2012); McPeak (2017); Mertz (2011); Mertz et al. (2010); Mertz et al. (2016); Nelimor et al. (2019); Oguntunde et al. (2017); Olusegun et al. (2018); Ouédraogo et al. (2017); Paeth (2011); Palazzo et al. (2017); Parkes et al. (2015); Parkes et al. (2018); Proud and Rasmussen (2011); Rauch et al. (2019); Salack et al. (2015); Salack et al. (2016); Scheiter and Savadogo (2016); Siebert (2016); Sissoko et al. (2011); Sossa et al. (2017); Stith et al. (2016); Sultan et al. (2013); Sultan et al. (2014); Sultan et al. (2019); Sultan et al. (2019); Sylla et al. (2015); Sylla et al. (2018a); Sylla et al. (2018b); Taylor et al. (2002); Traoré et al. (2011); Ugbaje et al. (2019); van Oort and Zwart (2018); van Wesenbeeck et al. (2016); Wang et al.

Sub-Saharan Africa or Africa**
98 (2017); Zorom et al. (2010)

Abidoye and Odusola (2015); Amjath-Babu et al. (2016); Asafu-Adjaye (2014); Azzarri and Signorelli (2020); Barrios et al. (2008); Bennetzen et al. (2016); Bodin et al. (2016); Bryan et al. (2018); Buhaug et al. (2015); Calzadilla et al. (2013); Chaney et al. (2014); Chen et al. (2018); Choptiany et al. (2017); Cobbing and Hiller (2019); Cooper et al. (2008); Corbeels et al. (2014); Dale et al. (2017); de Vrese et al. (2018); Descheemaeker et al. (2016); Dixon and Stringer (2015); Doelman et al. (2018); Döring (2020); Dunning et al. (2016); Egbendewe (2018); Fanzo et al. (2018); Faramarzi et al. (2013); Folberth et al. (2014); Garcia de Jalon et al. (2018); Garrity et al. (2010); Gray and Wise (2016); Hadebe et al. (2017); Haile (2005); Hasegawa et al. (2018); Henderson et al. (2016); Henderson et al. (2017); Hendrix and Glaser (2007); Hoffman et al. (2018); Huyer (2016); Jarvis et al. (2012); Jones and Thornton (2009); Jun (2017); Kamali et al. (2018); Kamali et al. (2019); Kamoni and Gicheru (2015); Lebel et al. (2015); Liu et al. (2013); Lobell et al. (2008); Lobell et al. (2013); López-Carr et al. (2014); Mahe et al. (2013); Naumann et al. (2014); Niles and Brown (2017); Nyboer et al. (2019); Ogundari et al. (2017); Onyutha (2018a); Oyekale (2015); Perez et al. (2007); Pironon et al. (2019); Prestele and Verburg (2020); Quintero and Cohen (2019); Ramin and McMichael (2009); Ramirez-Villegas et al. (2013); Richardson et al. (2018); Ringius (2002); Rippke et al. (2016); Rosenthal and Ort (2012); Rudi et al. (2012); Schlenker and Lobell (2010); Seo (2014); Seo et al. (2009); Serdeczny et al. (2017); Sheffield et al. (2014); Shi and Tao (2014); Sidibé et al. (2018); et al. (2019); Sonwa et al. (2017); Steward et al. (2018); Tabeau et al. (2017); Tesfaye et al. (2015); Thomas and Nigam (2018); Thornton and Herrero (2014); Thornton and Herrero (2015); Thornton et al. (2011); Tittonell et al. (2012); Torquebiau (2017); van Loon et al. (2019); von Uexkull (2014); von Uexkull et al. (2016); Vrieling et al. (2008); Vrieling et al. (2013); Waha et al. (2013); Waha et al. (2016); Waha et al. (2013); Wang (2005); Ward et al. (2014); Witmer et al. (2017); Wood et al. (2014); Yang et al. (2013)

\footnotetext{
* This category also includes documents dealing with BF and at least another West African country

** This category includes at least an African country outside West Africa
} 
Appendix 2: Agriculture subsectors in the analysed literature on the relationships between climate change and agriculture in Burkina Faso

Agriculture subsector $\begin{gathered}\text { Number of selected References } \\ \text { documents }\end{gathered}$

82

Ahmed et al. (2015); Amjath-Babu et al. (2016); Andam-Akorful et al. (2017); Barrios et al. (2008); Belesova et al. (2019); Bhaduri et al. (2011); Bodin et al. (2016); Bostick et al. (2007); Bunclark et al. (2018); Cobbing and Hiller (2019); Cooper et al. (2008); Dale et al. (2017); Dunning et al. (2016); Egbebiyi et al. (2019); Egbebiyi et al. (2019); Faramarzi et al. (2013); Faye et al. (2018); Folberth et al. (2014); Fonta et al. (2015); Gahi et al. (2015); Groten and Ocatre (2002); Guan et al. (2015); Guan et al. (2017); Hadebe et al. (2017); Haussmann et al. (2012); Hoffman et al. (2018); Jarvis et al. (2012); Jun (2017); Jung et al. (2012); Kamali et al. (2018); Kamali et al. (2019); Kima et al. (2014); Lebel et al. (2015); Liu et al. (2013); Lodoun et al. (2014); Mahe et al. (2013); Mishra et al. (2008); Nelimor et al. (2019); Oguntunde et al. (2017); Onyutha (2018a); Paeth (2011); Parkes et al. (2015); Parkes et al. (2018); Pironon et al. (2019); Quintero and Cohen (2019); Ramirez-Villegas et al. (2013); Rauch et al. (2019); Rosenthal and Ort (2012); Salack et al. (2015); Salack et al. (2016); Schlenker and Lobell (2010); Serpantié et al. (2019); Sheffield et al. (2014); Shi and Tao (2014); Sidibé et al. (2018); Siebert (2016); Steward et al. (2018); Sultan et al. (2013); Sultan et al. (2014); Sultan et al. (2019); Sultan et al. (2019); Sylla et al. (2018a); Sylla et al. (2018b); Tesfaye et al. (2015); Tittonell et al. (2012); Traoré et al. (2011); Ugbaje et al. (2019); van Loon et al. (2019); van Oort and Zwart (2018); vom Brocke et al. (2014); Vrieling et al. (2008); Vrieling et al. (2013); Waha et al. (2013); Waha et al. (2013); Wang et al. (2017); Waongo et al. (2014); Waongo et al. (2015); Ward et al. (2014); Wood et al. (2014); Yang et al. (2013); Zhang et al. (2019); Zouré et al. (2019) pastoralism

Crop production animal production (e.g. agro-pastoral systems; mixed crop-livestock systems)
Animal production and

7

96 Rasmussen et al. (2014); Rasmussen et al. (2015); Seo et al. (2009)

Abidoye and Odusola (2015); Asafu-Adjaye (2014); Asare-Kyei et al. (2017); Ayantunde et al. (2020); Azzarri and Signorelli (2020); Barbier et al. (2009); Bennetzen et al. (2016); Boansi et al. (2017); Boansi et al. (2019); Borona et al. (2016); Brockhaus et al. (2012); Bryan et al. (2018); Buhaug et al. (2015); Busby et al. (2014); Callo-Concha (2016); Callo-Concha (2018); Calzadilla et al. (2013); Chaney et al. (2014); Chen et al. (2018); Choptiany et al. (2017); Corbeels et al. (2014); D'haen et al. (2014); Defrance et al. (2017); Descheemaeker et al. (2016); Dixon and Stringer (2015); Döring (2020); Douxchamps et al. (2016); Egbendewe et al. (2017); Fanzo et al. (2018); Garcia de Jalon et al. (2018); Garnot et al. (2018); Gray and Wise (2016); Haile (2005); Hasegawa et al. (2018); Henderson et al. (2016); Henderson et al. (2018); Hendrix and Glaser (2007); Huyer (2016); Ingram et al. (2002); Johnson and Brown (2014); Jones and Thornton (2009); Kamoni and Gicheru (2015); Kima et al. (2015); Kniveton et al. (2012); Lahmar et al. (2012); Lay et al. (2009); Lobell et al. (2008); Lobell et al. (2013); Lokonon et al. (2019); López-Carr et al. (2014); Mertz (2011); Mertz et al. (2010); Mertz et al. (2016); Naumann et al. (2014); Nielsen and Reenberg (2010); Niles and Brown (2017); Ouédraogo et al. (2017); Oyekale (2015); Palazzo et al. (2017); Perez et al. (2007); Prestele and Verburg (2020); Ramin and McMichael (2009); Rasmussen (2018); Richardson et al. (2018); Rigolot et al. (2017); Ringius (2002); Rippke et al. (2016); Roncoli et al. (2001); Rudi et al. (2012); Sanfo et al. (2017); Seo (2014); Serdeczny et al. (2017); Sissoko et al. (2011); Sonwa et al. (2017); Sorgho et al. (2016); Sossa et al. (2017); Sylla et al. (2015); Tankari (2020); Thornton and Herrero (2014); Thornton and Herrero (2015); Thornton et al. (2011); Torquebiau (2017); Traore and Owiyo (2013); van Wesenbeeck et al. (2016); von Uexkull (2014); von Uexkull et al. (2016); Waha et al. (2016); Wang (2005); West et al. (2008); Witmer et al. (2017); Wittig et al. (2007); Zampaligré and Fuchs (2019); Zampaligré et al. (2014); Zidouemba (2017); Zorom et al. (2010); Zorom et al. (2013)

Agriculture and 31 forestry (e.g. agroforestry) Berthou et al. (2019); Bicher and Diedhiou (2018); Coulibaly et al. (2014); de Vrese et al. (2018);
Ahmed et al. (2016); Bayala et al. (2014); Belem and Saqalli (2017); Belem et al. (2011); Di Leo et al. (2016); Dimobe et al. (2018); Doelman et al. (2018); Egbendewe (2018); Gaisberger et al. (2017); Garrity et al. (2010); Hänke et al. (2016); Heubes et al. (2013); Jahel et al. (2017); Kalame et al. (2011); Klutse et al. (2018); Lambin et al. (2014); Luedeling and Neufeldt (2012); Mande et al. (2015); Ogundari et al. (2017); Olusegun et al. (2018); Proud and Rasmussen (2011); Scheiter and Savadogo (2016); Sidibe et al. (2019); Stith et al. (2016); Tabeau et al. (2017); Taylor et al. (2002); Thomas and Nigam (2018) Nyboer et al. (2019) 